UNIVERSIDADE DE SÃO PAULO

FACULDADE DE FILOSOFIA, LETRAS E CIÊNCIAS HUMANAS

DEPARTAMENTO DE LETRAS CLÁSSICAS E VERNÁCULAS

PROGRAMA DE PÓS-GRADUAÇÃO EM LITERATURA PORTUGUESA

FIORELLA ORNELLAS DE ARAÚJO

DO DUPLO À ABJEÇÃO: UMA LEITURA DE A CONFISSÃO DE LÚCIO DE MÁRIO DE SÁ-CARNEIRO 


$$
\text { UNIVERSIDADE DE SÃO PAULO }
$$

FACULDADE DE FILOSOFIA, LETRAS E CIÊNCIAS HUMANAS

DEPARTAMENTO DE LETRAS CLÁSSICAS E VERNÁCULAS

PROGRAMA DE PÓS-GRADUAÇÃO EM LITERATURA PORTUGUESA

\title{
DO DUPLO À ABJEÇÃO: UMA LEITURA DE A CONFISSÃO DE LÚCIO DE MÁRIO DE SÁ-CARNEIRO
}

Fiorella Ornellas de Araújo

\begin{abstract}
Dissertação de Mestrado apresentada ao Programa de Pós-Graduação em Literatura Portuguesa do Departamento de Letras Clássicas e Vernáculas da Faculdade de Filosofia, Letras e Ciências Humanas da Universidade de São Paulo (USP), para a obtenção do título de Mestre em Letras.
\end{abstract}

Orientadora: Profa. Dra. Lilian Jacoto 
Este trabalho é dedicado aos meus familiares, base de minha caminhada. 


\section{AGRADECIMENTOS}

Agradeço àqueles a quem dediquei o trabalho, bem como a minha orientadora, Lilian Jacoto, participantes da dissertação. 


\section{RESUMO}

O trabalho objetiva uma análise da obra A Confissão de Lúcio de Mário de Sá-Carneiro, pelas perspectivas do gênero e do sexo, do duplo e do abjeto, construídas através dos e nos protagonistas Lúcio-Marta-Ricardo. Elaborados como partes da ambigüidade realizada sob os desejos eróticos e relacionamentos auto-homoheterossexuais, nos quais as relações humanas representam uma entrega erótica, os personagens podem ser conseqüentemente vinculados às identidades não predominantes ou não normativas (como, por exemplo, a homossexualidade).

Percebe-se uma intensão de Mário de Sá-Carneiro de transgredir as leis da natureza, não só pela projeção da alma como também pela tentativa de encontrar o "outro", o duplo. Nesta linha de pensamento, vê-se na obra, portanto, uma atitude de identificação com as idéias da abjeção de questionamento à ordem estabelecida, na qual à controvérsia das identidades de gênero em relação ao posicionamento do femininomasculino dos personagens se vincula uma pretensão de vínculo do material com o espiritual. É importante ressaltar que para esta análise foram utilizados, como focos, os princípios teóricos de Julia Kristeva (abjeção), Judith Butler (sexo e gênero), Sigmund Freud (Psicanálise), bem como os do próprio autor e do modernismo português.

PALAVRAS-CHAVE: Modernismo Português; Mário de Sá-Carneiro; Orpheu; Duplo; Abjeção. 


\section{ABSTRACT}

The present work aims to analyse the book A Confissão de Lúcio from Mário de Sá-Carneiro, for the perspectives of the sort and the sex, of the double one and the abject one, constructed through and in the protagonists Lúcio-Marta-Ricardo. Elaborated as sexual parts of the ambiguity carried through under the erotic desires and relationships auto-homo-heterosexuals, in which the relations human beings represent a erotic delivery, the personages can consequently be tied with the not predominant or not normative identities (as, for example, to the homosexuality).

An intension of Mário de Sá-Carneiro is perceived to transgress the laws of the nature, for the projection of the soul as well as for the attempt to find the "other", the double one. In this line of thought, it is seen in the book, therefore, an attitude of identification with the ideas of the abjection of questioning to the established order, in which to the controversy of the identities of sort in relation to the positioning of the feminine-masculine of the personages if it associates with a pretension of bond of the material with the spiritual. It is important to stand out that for this analysis had been used, as centers of interest, the theoretical principles of Julia Kristeva (abjection), Judith Butler (sex and sort), Sigmund Freud (Psychoanalysis), as well as the ones of the proper author and the portuguese modernism.

KEYWORDS: Portuguese Modernism; Mário de Sá-Carneiro; Orpheu; Double; Abjection. 


\section{SUMÁRIO}

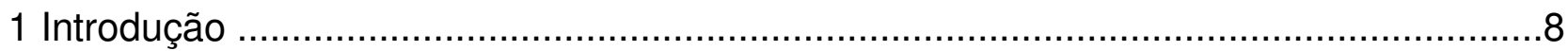

2 Estética modernista na Revista Orpheu...................................................... 13

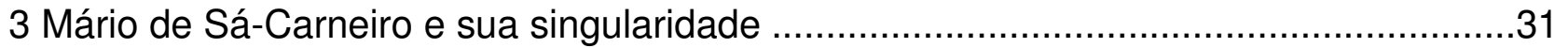

4 Uma leitura de A Confissão de Lúcio - Apresentação da narrativa..............................56

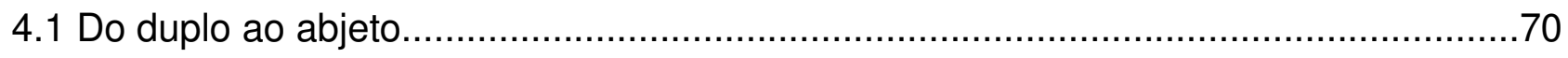

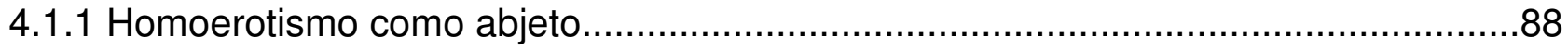

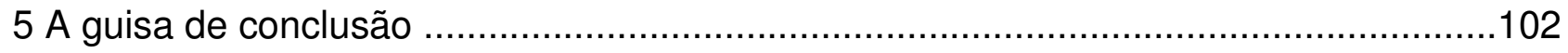

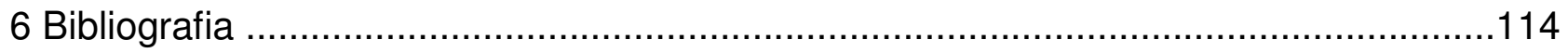




\section{Introdução}

Mário de Sá-Carneiro foi um dos principais participantes do "Orpheu", grupo que acompanhou os movimentos artísticos e literários correntes na época do início do século XX em outros pontos da Europa, e que publicou revista de mesmo nome. Essa revista pretendia uma classificação literária marcada por elevado nível artístico, que ligasse o desejo de destaques inéditos à consciência da necessidade de qualidade intrínseca da obra literária. A proposta levou os novos autores não só ao desafio de uma originalidade, como os mergulhou no entusiasmo de escandalizar o lepidóptero burguês, prazer recorrente nessa geração que pretendia usar uma linguagem extrema e estranha, questionadora dos valores burgueses.

Conhecida como arte independente, dentro do princípio de não ter nenhum princípio, Orpheu exigia coerência interna das obras que publicava; valorizava os seus significantes e sua organização, sua construção textual. A atitude dos integrantes do grupo procedia principalmente de sua preocupação manifesta de não fazer exceto arte, princípio da sua coesão como projeto.

Nascido em 1890, sob o amparo do Simbolismo, Mário de Sá-Carneiro não deixou de dialogar com a postura apolínea do movimento literário anterior, o parnasianismo, em contraponto com as tendências filosóficas centradas na intuição, no instinto, no inconsciente em detrimento da razão. Foi em um clima de transição, de oscilação entre o apolíneo e o dionisíaco ou clássico e romântico que nasceu o autor, em plena crise econômica portuguesa e em um clima de desprestígio do regime monárquico que se precipitou com o Ultimatum inglês (1890), preparando para a eclosão da república vinte anos depois. 
Por outro lado, é preciso reiterar o aspecto de total desmoronamento de valores, de completa decadência que ponteou a virada do século, arrastando os portugueses para um mundo implacável e frustrador. O caminho filosófico percorrido marca uma trajetória patente que vai de um racionalismo claro para um fragmentalismo total - da lógica à intuição. E essa caminhada é expressa pela literatura desde que os autores foram alterando a maneira de trabalhar a matéria literária. O conhecimento das raízes psicológicas através das essências deverá dar a chave para o conhecimento do interior profundo do indivíduo mergulhado no desmoronamento e nas ruínas, e Portugal é um país que conserva as marcas do passado - lá estão as ruínas como imagem concreta da deteriorização de um mundo de valores falsos e decrépitos - de valores vãos.

A estética modernista portuguesa se desenvolveu e aprofundou essencialmente com a amizade entre Fernando Pessoa e Mário de Sá-Carneiro. É através das cartas trocadas ao longo de três anos e meio (entre 20 de Outubro de 1912 e 18 de Abril de 1916) que vai ganhando consistência a profunda afinidade espiritual que existia entre os dois e que Ihes permitia compreenderem-se. Por outro lado, com base nestas correspondências que se vão definindo os critérios e as opções estéticas do modernismo e de todos os outros 'ismos' que nele coexistiram.

Assim, as Cartas a Fernando Pessoa oferecem e servem como orientação do percurso estético seguido em conjunto pelos dois poetas. Disto surge a necessidade de uma perspectiva global desse comum itinerário, de modo a ampliar a compreensão dos princípios que direcionam e determinam A Confissão de Lúcio. Será com base no estudo destes elementos que se verificará como os múltiplos 'ismos' (paulismo, interseccionismo, futurismo, sensacionismo) com que Sá-Carneiro tomou contato são 
modos duma única preocupação dominante e obsessiva: a busca do Ideal, anseio supremo cuja procura aparece como um movimento constante e principal da sua estética e parece ser a finalidade que norteou e o critério estético que motivou a sua realização.

Deste modo, a relação de Mário de Sá-Carneiro com Orpheu, e o contexto modernista em que a sua criatividade se iniciou e desenvolveu conduzem, invariavelmente, ao uso da teoria feita por Fernando Pessoa. O levantamento e ordenação das principais concepções e opções estéticas daquele autor implicam também idêntica sugestão, para além da análise da sua correspondência e obra.

Isso se justifica não só pelo temperamento predominantemente poético de Sá-Carneiro, alheio a qualquer ordem ou sistematização lógicas, como ainda pela forte ascendência que Pessoa exercia sobre o amigo. Esta influência dominante é detectável designadamente nas Cartas, onde se encontram explícitas referências a essa posição que Pessoa, admirado por Sá-Carneiro, detinha.

A dialética de Mário de Sá-Carneiro apresenta um drama global, o homem moderno caracterizado pela perplexidade diante de certos presentes vividos, pela existência que se sente às vésperas do fim, pela densidade trágica da dúvida que se vai transformando em suspeita, pelo questionamento constante da realidade com a presença de seres irreais, tendo como mola propulsora a dor. Nas representações do autor, sua poética e a expressão do homem moderno são manipuladas de modo fragmentado, estrangeiro, oculto. A representação da sua inadequação, do seu estilhaçamento, da insignificância de tudo e do nada configurado no resultado caótico da realidade constrói um túnel de imagens interseccionadas, que resulta no niilismo. 
Em $A$ Confissão de Lúcio tem-se a heterossexualidade como algo nãonatural e sim como uma condição que é construída culturalmente; por esse motivo, é necessário que diferentes mecanismos sejam utilizados constantemente, na tentativa de garanti-la como a sexualidade normativa. Dentre as possíveis estratégias utilizadas para reafirmar a heteronormatividade, interessam aqui os enunciados que são repetidos, de modo a produzir identidades de gênero e sexuais, reafirmando a heterossexualidade como norma. A identidade hegemônica não é perseguida apenas através da constante apresentação do mesmo, mas principalmente é reafirmada através da produção do estranho, do monstro, do abjeto, que funcionam, nesse contexto, como parâmetros de normalidade, como modos de garantir as normas regulatórias.

Heteronormatividade seria, então, o conjunto de normas, regras, procedimentos que regulam e normalizam não apenas as identidades sexuais como também as identidades de gênero, estabelecendo maneiras usuais de ser, modos de comportamento, procedimentos determinados, atitudes. Em contrapartida, um determinado tipo de homoerotismo é produzido de modo abjeto na obra, apresentando-se como um elemento que está na zona de inteligibilidade, operando como instaurador do duplo personagem Lúcio-Ricardo. Sua função é tão somente afirmar as identidades dos personagens, de maneira a evitar que eles saiam da fronteira para o não-lugar, aquele onde estão os sem-nomes, os impensáveis. Vale ressaltar que o abjeto remete a alguma coisa da ordem da animalidade, da morte e da visceralidade, que escapa da inscrição simbólica, e que ameaça a estabilidade da imagem corporal ideal. A atualidade dos fluxos vertiginosos, das metamorfoses - em que nada é sólido ou seguro - constitui o que Kristeva considera a dinâmica da abjeção: "Não é a falta de limpeza ou saúde que causa 
abjeção, mas o que perturba a identidade, o sistema, a ordem. O que não respeita limites, posições, regras. $O$ 'entredois', o ambíguo, o compósito” ${ }^{1}$.

Deste modo, para apresentar tais idéias, este trabalho está dividido em três capítulos. No primeiro abordam-se os valores e principais pressupostos filosóficos, compartilhados tanto por Mário de Sá-Carneiro como Pessoa, que compõem a estética modernista. Num segundo momento, especificam-se valores e facetas pertencentes unicamente ao primeiro autor, ou seja, suas singularidades. No terceiro capítulo, faz-se uma leitura de $A$ Confissão de Lúcio, em três sub-capítulos: análise estrutural (elementos da narração e da história); Lúcio e Ricardo, o "duplo"; o homoerotismo como abjeto.

\footnotetext{
${ }^{1}$ KRISTEVA: $1985 ; 4$
} 


\section{Estética modernista na Revista Orpheu.}

Entre 1912 e 1916, situam-se vários acontecimentos importantes para a compreensão da questão estética em Mário de Sá-Carneiro, pois é neste contexto que acontecem o projeto modernista, a preparação e publicação dos números ${ }^{2}$ da revista Orpheu e uma sucessão tumultuosa de 'ismos' ou teorias estéticas de teor vanguardista (paulismo, interseccionismo, futurismo e sensacionismo). Trata-se ainda do período de principal produção literária de Sá-Carneiro e os quatro últimos anos da sua vida.

Sendo o objetivo, neste primeiro capítulo, de analisar a relação de SáCarneiro com a estética modernista portuguesa, destacando a ação que o poeta teve na criação e evolução de alguns dos seus principais valores, interessa sobretudo o estudo da teoria estética 'interna' da geração do Orpheu, independentemente de uma análise sóciocultural e da atenção à diacronia de todos os seus fatos.

Desde 1912 que Mário de Sá-Carneiro está em contato direto com a arte e a literatura modernas. Permeável à inovação, o poeta identifica-se com o antitradicionalismo e o cosmopolitismo típicos das vanguardas, fazendo questão de estar onde as coisas acontecem: "Paris! Paris! Orgíaco e solene, monumental e fútil’3. Este amor enorme a Paris (cidade que congregava as principais manifestações artísticas da época, bem como a presença de muitos artistas) tão lucidamente sentido, faz com que para o poeta a grande capital se destaque em absoluto dentre as outras.

O "caráter europeu" ou este "querer-ser-europeu" estão relacionados ao fato

\footnotetext{
${ }^{2}$ Ao todo foram publicados dois números de Orpheu, pois o terceiro nunca chegou a sair devido a complicações financeiras. Carta de 13 de Setembro de 1915, in C. 11, pp. 80-85.SÁ-CARNEIRO: 1979; pp. 80-85.

${ }^{3}$ SÁ-CARNEIRO: 1980; 281-282
} 
de a Europa afirmar-se, à época, como a "região civilizada", "o tipo e a direção a todo o mundo", , ponto de referência fundamental e obrigatório, era também sinônimo de uma dupla meta: o desejo de universalidade impondo a superação das fronteiras portuguesas e uma vontade de ruptura com a literatura do passado, sugerindo um rumo ao futuro e ao novo:

\begin{abstract}
"Não somos portugueses que escrevem para portugueses; (...) somos portugueses que escrevem para a Europa, para toda a civilização; nada somos por enquanto, mas aquilo que agora fazemos será um dia universalmente conhecido e reconhecido. (...) Não pode ser de outra maneira, realizamos condições sociológicas cujo resultado é inevitavelmente esse. Afastamo-nos de Camões, de todos os absurdos enfadonhos da tradição portuguesa e avançamos para o futuro". 5 .
\end{abstract}

Sá-Carneiro acusa semelhante ambição universalista, ao considerar altamente positiva e desejável a ação de “(...) tornar conhecidos no mundo os poetas portugueses de hoje, fazer saber que num canto amargurado e esquecido da Europa, uma poesia grande e nova se começa a desenvolver rasgando horizontes desconhecidos, perturbadores e belíssimos. "6.

Do mesmo modo que o individualismo implícito na exigência de originalidade a reforça, assim também em ambos, uma certa forma (revolucionária) de patriotismo funciona como uma motivação que ativa a universalidade, a qual, além de ser uma recriação da antiga ambição expansionista, também reaparece no contexto de Orpheu enquanto desejo de "uma metamorfose total da imagem, ser e destino de Portugal".".

\footnotetext{
${ }^{4}$ PESSOA: s/d.; 121-122

${ }^{5}$ Idem, ibidem.

${ }^{6}$ SÁ-CARNEIRO: 1978; 46

${ }^{7}$ LOURENÇO: 1982; 86
} 
O nacionalismo modernista surge como um encarar a sério a arte e a vida ${ }^{8}$, revelando a implicação fundamental que ambas mantêm para o artista moderno e ao mesmo tempo a importância da tarefa estética, a qual não deve seguir nenhum critério exterior à própria arte, mas manter como única finalidade o "aumentar a autoconsciência humana"9. Vale ratificar que aquele contém uma afirmação transnacionalista ("querer-sereuropeu"), dimensão futurante e renovadora, orientando-o para uma descoberta de novas expressões da sensibilidade estética e distinguindo-o do nacionalismo saudosista seu contemporâneo, romanticamente fixado num retorno mítico ao passado, considerado como único meio de um autêntico ressurgimento pátrio.

Assim, a reivindicação da novidade e da dimensão moderna passava obrigatoriamente por uma perspectivação européia do modo de ser literário português, ou seja, da necessidade de questionar a literatura nacional e libertá-la do sentimento de inferioridade face ao estrangeiro. Para tanto, deveria provocar um verdadeiro despertar nacional, reformar a mentalidade cultural portuguesa e “(..) agir sobre o psiquismo nacional, que precisa [de ser] trabalhado e percorrido em todas as direcções por novas correntes de idéias e emoções que nos arranquem à nossa estagnação."10, ou seja, "entrar em actividade européia mediante o contacto com outras culturas", ordenando e selecionando positivamente tais contatos de modo a atingir a complexa essência da arte moderna: arte-todas-as-artes, mistura e intersecção de todas as partes do mundo.

Além de cosmopolitismo, universalismo e originalidade, Orpheu contém em si o projeto de uma "estética aberta", que se mostra disponível ao que é diferente, eclético, e da qual fazem parte uma plasticidade e versatilidade multiplicadas pelo

\footnotetext{
${ }^{8}$ PESSOA: 1985, p. 45.

${ }^{9}$ Idem, s/d.; 186

${ }^{10}$ Idem,: 1985, 45

${ }^{11}$ Idem: s/d.; 120-121
} 
sensacionismo (a ser examinado posteriormente), disciplina anárquica viável para esse movimento sintético, implicando um desdobramento em todas as experiências culturais ou potencialidades civilizacionais possíveis.

Por outro lado, propõe-se como fim criador-de-civilização de toda a obra artística, pretendendo "pensar a fundo (...) essa terrível missão (...) que é fazer arte", exigindo ao mesmo tempo "uma perfeição absoluta no realizado, uma seriedade integral no escrito", evitando, assim, fazer arte para "fins inferiores" ou à que "(...) não tem Além nem outro propósito que o, por assim dizer, decorativamente artístico"12.

Em suma, para abolir o tradicionalismo e provincianismo portugueses, os órficos preconizavam uma verdadeira ampliação da mentalidade cultural nacional e conseqüente apropriação criativa dos valores europeus, constituindo importante estratégia na tarefa de renovação estrutural da sensibilidade estética vigente, única que, por sua vez, possibilitaria um reencontro decisivo da genuína "alma literária nacional" consigo mesma.

Ser modernista implicava ainda uma forma de estar-no-mundo, a praticar certas atitudes, expressões e modos - que pretendiam sublinhar a diferença e a distância do grupo face à "inferioridade da subgente normal" - em que também predominavam 'ismos', como europeísmo, individualismo, elitismo (sobretudo nas coisas espirituais) e culto do esoterismo.

A frase citada é de Sá-Carneiro, que, com suas ânsias enternecidas - “(...) Só com a minha alma poderia matar as minhas ânsias enternecidas (...)"13-, rodopio

\footnotetext{
${ }^{12}$ PESSOA: s/d; 47

${ }^{13}$ SÁ-CARNEIRO: 1991, 56
} 
nevoento - “(...). E, de súbito, sem saber como, num rodopio nevoento, encontrei-me sentado em um sofá, (...) $)^{m 14}$, dentre tantos outros exemplos, revelam uma inovadora imaginação verbal e metafórica, marcada por estranheza, excentricidade e rebuscamento, contribuições ao vocabulário órfico. O significado dessas expressões, um pouco obscuro, está ligado a essa necessidade modernista de marcar a diferença e a um efeito de ineditismo chocante, que o grupo procurava deliberadamente obter com as suas singulares iniciativas estéticas.

Lepidóptero é outra palavra da consciência modernista, cunhada por SáCarneiro para designar os seres comuns, nos quais criatividade, sensibilidade e inteligência estariam ausentes, e os quais consecutivamente constituíam o alvo privilegiado das mistificações e blagues modernistas. Com um aspecto lúdico, misto de humor e provocação que igualmente surgem associados a essa expressão, o pintor Almada Negreiros precisa - embora não totalmente, devido ao uso excessivo da blague o significado, para Orpheu, desta quase-senha:

“(...) A mais profunda das (...) criações de vocábulos perjurativos em dias do Orpheu. Lepidoptero [sic] simula com o próprio vocábulo palavra erudita com todo o fingimento de individuar categoria de excepção. (...) É tão feliz esta criação que não deriva de nenhuma possibilidade filológica como afinal o parece. Lepidoptero [sic] não tem nada que ver com a natureza. Assim mesmo é perdurável. A ciência actual está mobilizada para debelar esta autêntica existência que nada tem que ver com a natureza. Não será que a natureza se tenha pré-fabricado este subproduto para que bem bem se veja o que acontece quando a natureza não está?"15.

\footnotetext{
${ }^{14}$ Idem, ibidem, p. 56

${ }^{15}$ Orpheu: s/d.; 39
} 
A "intenção de blague" ultrapassa o sarcasmo simplista ou o exibicionismo superficial devido à sutil ironia com que é realizada e ao efeito estético conscientemente procurado, revelando-se, assim, como uma tática de combate eficaz, por estar integrada numa estratégia consciente de eliminação radical do provincianismo mental português. Assim, "uma 'blague', pode pôr - ou traduzir - os mesmos problemas que um acto 'sério'”16, ou seja, a ironia é a segunda dimensão de uma seriedade autêntica ${ }^{17}$, por ela funcionar como uma espécie de seu reverso indissociável que constantemente a põe à prova, sendo por isso mesmo e paradoxalmente, a única que lhe pode dar uma consistência não ilusória.

Tanto a ironia como a própria blague são elementos ou marcas inconfundíveis dos modernistas, de um espírito que mistura irreverência, desafio e humor, combinando a seriedade dos propósitos artísticos e um entusiasmo conscientemente combativo e dinâmico.

A primeira surge deste modo como estratégia e consciência modernista, suporte do componente ideológico da estética dos novos poetas, funcionando como uma superestrutura da sua arte, uma vez que, ao propugnar a eliminação do provincianismo mental português (estado de espírito de 'consciência feliz', horizontes estreitos e individualidade nula, justamente incapaz de ironia) como parte da missão de Orpheu, há só uma solução, como diz Pessoa, é o saber que ele existe, e para a realização desta ironia se exige apenas 0 não se ser provinciano ${ }^{18}$. Nos textos esta estratégia é conseguida através de valorizações estéticas, pelo uso da contradição, do paradoxo, da incoerência e, consecutivamente, do desdobramento e da dispersão, evidenciando um

\footnotetext{
${ }^{16}$ LOURENÇO; 1974: 66

17 Idem, ibidem.

${ }^{18}$ PESSOA; 1946: 185 e 184.
} 
efeito de pluralidade - palavra de ordem tipicamente órfica: "Que cada um de nós multiplique a sua personalidade por todas as outras personalidades ${ }^{\prime 19}$.

Esta nova arte, do instável em vez do seguro e certo, faz com que a alma poética, deixando para trás todo um universo de certezas indiscutíveis e descobrindo a possibilidade do abismo dissipador da nitidez dos princípios lógicos, enfrente, só, a sua própria incontrolável complexidade interior e também a imprevisibilidade essencial de tudo.

Essa revelação está vinculada a uma determinada concepção da realidade e da verdade contida no transcendentalismo panteísta ${ }^{20}$, sistema filosófico reinventado por Pessoa nos seus ensaios iniciais (1912) e desenvolvido em textos posteriores, no qual a contradição é um elemento fundamental, pois tudo o que existe (matéria, espírito e a idéia de Deus) é e não é ao mesmo tempo, ou seja, uma afirmação é tanto mais verdadeira quanto maior contradição envolve:

"Não há critério de verdade senão não concordar consigo próprio. O universo não concorda consigo próprio, porque passa. A vida não concorda consigo própria, porque morre. O paradoxo é a fórmula típica da Natureza. Por isso toda a verdade tem uma forma paradoxal. (...) Tão pouco se deve o artista preocupar com a verdade do que descreve [pois esta] pertence à ciência, à moral, à vida prática." ${ }^{21}$.

O trecho aborda a convicção de que a realidade é ilusória, de que a verdade não é única, mas múltipla, ou seja, de que "embora a perfeição suprema (que é inatingível) seja uma só, no entanto a perfeição relativa tem como característica a

\footnotetext{
${ }^{19}$ Idem; s/d: 124.

${ }^{20}$ É importante ressaltar que esta filosofia artística desenvolvida por Pessoa virá a ser o sensacionismo.

${ }^{21}$ PESSOA: s/d.; 217-218
} 
pluralidade. ${ }^{22}$. Este aspecto explica o ceticismo e a necessidade de (auto-)mistificação "a vontade de substituir a referência à Realidade enquanto representação pela linguagem mesma $^{, 23}$ - da estética órfica, e, ainda, um forte idealismo dualista. Por outras palavras, em ambos os poetas existe um idêntico sentimento da imperfeição da realidade presente e a tendência para transpor poeticamente esta inquietação procurando, quer entrever a realidade da beleza que em outra parte é divina (Pessoa), quer rasgar véus sobre o Além (Sá-Carneiro). Assim o idealismo de Orpheu é por essência negativo, pois o Transcendente inteiramente concebido pela imaginação manifesta-se apenas como sonho de si próprio, sendo não só absolutamente irreal e ilusório como ainda sentido como Mistério ${ }^{24}$.

Apesar de uma deliberada distância face ao real poder ser considerada símbolo de superioridade, pela divinizante ironia com que é praticada, não deixa de se tornar redutora da possibilidade de encontrar alguma consistência na experiência da realidade, enquanto uma sistemática incoerência saída da incoerência ${ }^{25}$. Assim, ao reconhecer-se tal tentativa e o risco que a envolve desnecessários porque inúteis, o que resta do mundo, na sua vacuidade angustiante, e do "eu", esvaziado da sua alma adquirida, totalmente precário na sua frágil condição poética, sentindo-se apenas "contos contando contos, nada" é justamente o $\mathrm{Nada}$ - ressurgindo a desintegração espiritual ${ }^{26}$ exibindo claramente o seu reverso nilista -, ou o apreender no Nada o Ser, já que o poeta, através do sentir a angústia essencial, a revelação da própria transcendência interior, ao mesmo tempo que descobre o enraizamento na negatividade da sua origem

\footnotetext{
${ }^{22}$ PESSOA: s/d.; 221

${ }^{23}$ LOURENÇO: $1974 ; 66$

${ }^{24}$ PESSOA: 1986; 52

25 "Todavia, eu era pagão dois parágrafos acima, mas, ao escrever este, já não o sou. Traduzo na prática, tanto quanto me é possível, a desintegração espiritual que proclamo. Se alguma vez sou coerente, é apenas como incoerência saída da incoerência. (...)." (PESSOA; 1986: 139-140).

${ }^{26}$ Ibidem.
} 
mais originária, surpreende-se como olhar atento a esse salto do ôntico para o ontológico que quer saltar até ao fundamento sem fundo de si mesmo.

Do ponto de vista estético-literário, no período entre 1912 e 1916 há nessa parceria uma grande produção de projetos estéticos ("ismos"), sendo difícil dispor uma sucessão linear ou uma hierarquização clara dos mesmos, haja vista que tanto nos textos de Pessoa, o mais ativo na criação deles, como nos de Sá-Carneiro, freqüentemente constam as mesmas designações a sentidos ou a datas de aparecimento diferentes. Este estado anárquico é explicável, por um lado, pela própria natureza modernista - espírito mistificador, excêntrico e contraditório na sua essência -, e, por outro, por terem surgido de modo transitório, como experimentações desordenadas, tentativas de substituição radical dos critérios estéticos existentes e de produção de outras expressões literárias mais adequadas à nova noção do mundo, da arte e até da vida. Vale relembrar que a revista Orpheu queria afirmar-se como a soma e a síntese de todos os movimentos literários modernos (europeus e portugueses), surgindo como momento culminante de concretização desse espírito sintético e de todos os ideais e teorias que Fernando Pessoa e Sá-Carneiro vinham ensaiando e desenvolvendo, possibilitando a passagem da anarquia criativa à ordenação dessa criatividade. Para pontuar a relação de Mário de SáCarneiro com os valores de alguns desses movimentos, como parte essencial do seu percurso poético, levando-nos à compreensão de sua questão estética, eis adiante uma seqüência de alguns desses "ismos".

Em 1912, em sua estréia como crítico, Fernando Pessoa anunciou nos seus artigos "A nova poesia portuguesa sociologicamente considerada" e "A nova poesia portuguesa no seu aspecto psicológico", para a revista A Águia, a novidade da atual corrente literária, como Ihe chamava, referindo-se aparentemente só ao saudosismo. 
Entretanto, o poeta estabelece nessas teorizações sobre a nova poesia portuguesa os critérios estéticos - diferenciando-os do contexto poético saudosista e dos seus antecedentes simbolistas - e os pressupostos metafísicos que serão, na sua maior parte, os do futuro Orpheu. Seguindo tais princípios doutrinais, em fevereiro de 1914, Pessoa publica no único número da revista $A$ Renascença $a^{27}$ o poema Paúis, que assinala tanto sua estréia poética (trata-se da publicação de seu primeiro poema), como o momento de afirmação dos modernistas por formalizar a ruptura com a tradição portuguesa, o "lepidopterismo nacional".

A correspondência entre Sá-Carneiro e Pessoa registra desde o seu início traços desses novos valores estéticos e filosóficos, onde já se percebem características paúlicas, como na carta de 3 de fevereiro de 1913, na qual Sá-Carneiro, comentando poesias do amigo para um projeto de livro intitulado Gládio, afirma ter Pessoa criado uma nova linguagem, caracterizando-a na seguinte forma poética: "Entre os seus versos correm nuvens e essas nuvens é que encerram a beleza máxima." ${ }^{28}$. Conforme esta passagem, para Sá-Carneiro, essa nova expressão poética atinge a suprema beleza ao conseguir uma notável força de sugerir, tópico simbolista que vem a ser retomado pelo paulismo, e uma tendência principal e permanente na estética sá-carneiriana.

Sá-Carneiro valoriza poeticamente a sugestão ${ }^{29}$, explorando o efeito que ela produz (uma atmosfera própria do sonho, vaga e enevoada), ambiente ideal para tal poeta que essencialmente manuseia o mistério e interroga o Além, pois segundo este: "há Arte

\footnotetext{
${ }^{27}$ Renascença Portuguesa: sociedade portuense fundada por Teixeira de Pascoaes, cuja atividade esteve ligada ao Saudosismo e que teve como órgão a revista $A$ Águia; a qual, foi recentemente reeditada pela Editora Zéfiro.

${ }^{28}$ SÁ-CARNEIRO; 1978: 62

${ }^{29}$ A importância da "sugestão" e do "vago" estão documentadas em outros trechos das correspondências, como em: SÁ-CARNEIRO; 1978: 55, onde o poeta refere projetos literários seus afirmando que são "material mais vago e mais intenso - superior portanto."; e Ibid., p. 82, 85 e 95, que abordam "O Homem dos Sonhos", "O Fixador de Instantes" - "narrativa alucinada" - e "Bailado", sobre o qual o poeta diz: "trata-se mais de uma poesia do que de um trecho de prosa. Mas em escritos como estes o ritmo parece-me imprescindível, pois ajuda muito a sugestão.".
} 
que se aprecia melhor antes de se procurar compreendê-la. Pressentir é mais do que sentir"30. Ainda sobre os versos de Paúis, comenta: "Eu sinto-os, eu compreendo-os e acho-os simplesmente uma coisa maravilhosa; uma das coisas mais geniais que de você conheço. É álcool doirado, é chama louca, perfume de ilhas misteriosas o que você pôs nesse excerto admirável aonde abundam garras. 31 .

Deste modo, segundo Pessoa, do título Paúis se passou à designação "paulismo", corrente que surge afirmando o seu antagonismo face à Renascença Portuguesa e, posteriormente, à coexistência com outra corrente, o sensacionismo ${ }^{32}$. Sabe-se que esta distinção é um mero artifício intelectual, pois todos os 'ismos' têm o espírito decadente como base comum. O decadentismo português, além de "proveniente da falência de todos os ideais passados e mesmo recentes',33, é misto, definindo-se, ainda segundo Pessoa, através de uma composição de tipos diferentes de decadentismo, definição que pode transpor-se para caracterizar a vincada faceta decadentista encontrada em Sá-Carneiro. Assim, em primeiro lugar, ela é “uma continuação (...) daquela parte do decadentismo que representa (...) uma revolta contra as regras, uma introspecção excessiva"34; em segundo lugar, reivindica "absoluta indiferença para com humanidade, a religião e a pátria,35. Disto resulta um "terceiro tipo de decadentismo", que surge precisamente "na corrente portuguesa que veio a manifestar-se em 'Orpheu”, e constitui "uma exacerbação dos dois reunidos"36.

Assim, do ponto de vista teórico, os vários 'ismos' acabam por afirmar-se mais enquanto modos do sensacionismo - o qual assume uma espécie de posição

\footnotetext{
${ }^{30}$ SÁ-CARNEIRO; 1978: 117

${ }^{31}$ Idem, ibidem: 115-117

${ }^{32}$ PESSOA; s/d: $125-126$

${ }^{33}$ Idem, ibidem: 167

${ }^{34}$ Idem, ibidem; s/d: 176

${ }^{35}$ Idem, ibidem; s/d: 204

${ }^{36}$ Idem, ibidem; s/d: 176
} 
englobante, de supremacia estética em relação ao conjunto deles - do que propriamente como tendências literárias independentes.

Outro fator relevante à análise da estética de Mário de Sá-Carneiro é a conseqüência literária órfica do cubismo, o interseccionismo. Trata-se do processo de intelectualização pelos órficos da "decomposição do modelo" que os cubistas realizam, ou seja, ao ser transferida da pintura para a literatura, aquela é recriada em termos do que julgam ser a "esfera própria dessa decomposição - não as coisas, mas as nossas sensações das coisas ${ }^{37}$, resultando na principal atitude dos sensacionistas, para os quais “a única realidade da vida é a sensação e a única realidade em arte é a consciência da sensação,38.

Por sua vez, o interseccionismo, definindo-se como consciencialização dessa deformação de plano, incorpora a técnica cubista, a partir do qual cada sensação passa a ser "na realidade, constituída por diversas sensações mescladas",39, revelando-se como processo privilegiado de execução do sensacionismo, o qual "pretende realizar na arte a decomposição da realidade nos seus elementos geométricos psíquicos” (Pessoa; s/d: 186). Um excerto de A Confissão de Lúcio ratifica tal teoria:

"De forma que a luz total era uma projeção da própria luz — em outra luz, seguramente, mas a verdade é que a maravilha que nos iluminava nos não parecia luz. Afigurava-se-nos qualquer outra coisa - um fluido novo. Não divago; descrevo apenas uma sensação real: essa luz, nós sentíamo-la mais do que a víamos, E não receio avançar muito afirmando que ela não impressionava a nossa vista, mas sim o nosso tato. Se de súbito nos arrancassem os olhos, nem por isso nós deixaríamos de ver. E depois -

\footnotetext{
${ }^{37}$ Idem, ibidem; s/d: 137

${ }^{38}$ Idem, ibidem

${ }^{39}$ Idem, ibidem
} 
eis o mais bizarro, o mais esplêndido — nós respirávamos o estranho fluido. Era certo, juntamente com o ar, com o perfume roxo do ar, sorvíamos essa luz que, num êxtase iriado, numa vertigem de ascensão — se nos engolfava pelos pulmões, nos invadia o sangue, nos volvia todo o corpo sonoro. Sim, essa luz mágica ressoava em nós, ampliando-nos os sentidos, alastrandonos em vibratilidade, dimanando-nos, aturdindo-nos... Debaixo dela, toda a nossa carne era sensível aos espasmos, aos aromas, às melodias!..."

Encontramos em Sá-Carneiro o essencial da estética sensacionista, em toda a sua complexidade. Por um lado, a tendência para "tornar o mundo exterior inteiramente irreal'\$1, conseguida através de uma espécie de ‘deslocação' pela qual a realidade do real é anulada como todo e substituída por uma subjetividade cuja expressão, entre delirante e absorvente, surge totalmente condicionada pela emoção ${ }^{42}$. Por outro, essa expressividade, dominada por uma análise mórbida das sensações, atinge uma intensidade desmedida que desestabiliza quaisquer limites da imaginação comum. Isto justifica a avançada desarticulação de linguagem lógica que é encontrada em seus textos (como no excerto supracitado), símbolo da presença inédita de emoções, de idéias, de febres e de delírios, agudeza sensorial que se transforma numa autêntica e inultrapassável necessidade anímica.

Além de em quase todas as suas obras notarem-se exemplos de hibridismo estético, mistura de paulismo, interseccionismo, futurismo, sensacionismo (fora aspectos do romantismo ou surrealismo), suas produções literárias também indicam um duplo processo de apagamento e transfiguração do mundo real que permanece fundamentando

\footnotetext{
${ }^{40}$ SÁ-CARNEIRO, 1991: 32

${ }^{41}$ PESSOA; s/d: 149

42 “(...) um dos princípios sobre que assenta o (...) sensacionismo - mau grado, é claro, ele não assentar em princípio nenhum - é o da expressão ser condicionada pela emoção a exprimir”. (Idem, ibidem; s/d: 163).
} 
negativamente a sua estética. Deste modo, Sá-Carneiro produz uma eliminação do natural intervalo entre o poetar e a realidade:

"É o poema mesmo que cria a realidade que nós tocamos depois de o ter lido. Não é descrição, nem comentário, nem alusão, nem símbolo, nem mesmo sugestão. É imediatamente a respiração e a expiração poética do mundo. (...) A poesia não vem depois do mundo, imagem tranqüila, desesperada ou sublime desse mundo. O mundo que há é esse que o poema faz existir ou inexistir." 43 .

A exposição pormenorizada que Sá-Carneiro faz a Pessoa ${ }^{44}$ do projeto Novela Romântica relata sobre a forma determinada como o poeta se posiciona acerca de alguns dos elementos de seu hibridismo. A novidade deste "enredo complicado e bizarro, (...) incoerente e exagerado", consiste propriamente na "intersecção românticosensacionista da psicologia de Heitor de Santa-Eulália`, personagem central da novela. Este entrecruzamento, por sua vez, produzirá dois tipos de "anacronismos":

“(...) psicológicos: isto é: pormenores que, por forma alguma, se poderiam suscitar na alma de um homem de 1830. Mas isso muito propositadamente. Assim como que criarei um 'romantismo outro' - enfim: um dos meus personagens interseccionistas mascarado de romântico (...)"46.

Sá-Carneiro acrescenta ainda o que considera ser um detalhe muito importante: "o estilo será o meu - e daqui virá o principal anacronismo - estilo pois interseccionista mas misturado de romantismo na sua chama, na sua violência abrasadora de 'infernos', 'céus', etc.” 47

\footnotetext{
${ }^{43}$ LOURENÇO, 1982: 167

${ }^{44}$ SÁ-CARNEIRO, 1979: 61-68, 148-149, 152-154.

${ }^{45}$ Idem, ibidem: 152

${ }^{46}$ Idem, ibidem: 64

${ }^{47}$ Idem, ibidem: 74
} 
Mas a Novela Romântica revela-se ainda muito mais ampla, dada a afinidade que apresenta com $A$ Confissão de Lúcio e algumas novelas de Céu em Fogo (como A Grande Sombra, Eu próprio o Outro e Ressurreição), não só pela mesma estrutura de irrealidade que invade as relações entre as personagens principais - além de Heitor de Santa-Eulália, Estanislau Belkowsky - como, ainda, por um efeito semelhante de desdobramento psíquico e/ou triangulação afetiva, conseguido, em grande parte, através de inquietantes jogos de espelhos, neste caso, entre os dois amigos de alma. Com efeito, "Heitor reconhecerá em Estanislau a parte mais estranha que há em si próprio e ele menos conhece e se pode explicar. Estanislau será para Heitor a prova de que existem as suas estranhezas (...). Estanislau será dentro da novela o padrão, a mira do seu elemento interseccionista: como o romance amoroso de Heitor, o seu puro elemento Romântico."48.

Na frase “...Assim éramos nós obscuramente dois, nenhum de nós sabendo bem se o outro não era ele-próprio, se o incerto outro viveria..." ${ }^{49}$, escolhida por SáCarneiro como epígrafe d'A Confissão de Lúcio, parece ser duplamente sintomática: por um lado, sintetiza de forma sugestiva o tortuoso modo de relacionamento que, por sua vez, provoca uma atmosfera específica de ambigüidade em que se movem todas as suas personagens; por outro lado, indica como a amizade, relação afetiva que Sá-Carneiro privilegiava, surge motivando de forma difusa e um tanto equívoca, este sucessivo 'vaivem' entre Ele-próprio e o Outro, proeminente numa estética que amalgama vida e obra, existência e fingimento.

Outro pormenor importante do ponto de vista estético deste projeto literário,

\footnotetext{
${ }^{48}$ Idem, ibidem: $152-153$

49 A frase é de Na Floresta do Alheamento, texto de Fernando Pessoa, circunstância que parece ser significativa.
} 
que se repete, aliás, noutras passagens d’A Confissão de Lúcio, é a dimensão "futurante" que ele contém. A relação de Mário de Sá-Carneiro com tal elemento, embora possa ser considerada como superficial, envolveu porém um profundo fascínio, o qual surge, aliás, largamente documentado na obra do poeta que se declarou "doente-de-Novo", como ilustração a isso, vale ressaltar a supracitada passagem referente ao trecho da "luz" delirante ${ }^{50}$.

Tanto em Céu em Fogo como em A Confissão de Lúcio, encontramos a indicação desta preferência exaltada pela diversidade tumultuosa das atmosferas artificiais, típicas da vida urbana, que aparece muitas vezes explicitamente ligada ao seu amor pela capital, esse "único ópio louro para a [sua] dor - Paris!"51, a cujo movimento tem por hábito entregar-se em voluptuosidade, numa espécie de terapêutica, algo decadente, contra a angústia permanente em que vive mergulhado.

"Só posso viver nos grandes meios. Quero tanto ao progresso, à civilização, ao movimento citadino, à actividade febril contemporânea!... Porque, no fundo, eu amo muito a vida. Sou todo de incoerências. Vivo desolado, abatido, parado de energia, e admiro a vida, entanto como nunca ninguém a admirou!

Como gostássemos, em muitas horas, de nos embrenhar pela vida normal e nos esquecer a nós próprios - frequentávamos bastante os teatros e os music-halls, numa ânsia também de sermos agitados por esses meios intensamente contemporâneos, europeus e luxuosos.. ${ }^{52}$.

Numa carta a Fernando Pessoa fala também da necessidade que sente, em

\footnotetext{
${ }^{50}$ Idem, 1991: 32

${ }^{51}$ Idem, ibidem: 46

${ }^{52}$ Idem, ibidem: 48
} 
determinadas momentos, de encontrar um certo 'anestesiamento', o qual se resume "em levar uma vida oca, inerte, humilhante - e doce contudo,53. Para esta, tem uma 'receita' precisa: "saio de manhã, dou longos passeios, vou aos teatros, passo horas nos cafés. Consigo expulsar a alma. E a vida não me dói, ${ }^{54}$.

Por outro lado, as suas realizações ditas futuristas podem, numa primeira leitura, ser abordadas como representando o seu lado mais snob e frívolo, sensível à efemeridade mundana e excêntrica das modas a que adere. O que fica patente tanto na atmosfera peculiar que caracteriza suas obras, como nos seus temas principais, é a presença de marcas futuristas: o elogio da Magia contemporânea, a beleza dura dos aços, a preferência pelo movimento e as maravilhosas viagens aparecem recorrentemente na sua ficção poética, sob a forma de motivos que, embora surjam secundarizados em relação aos temas centrais, não deixam de ter uma importância e um peso que devem ser considerados.

Acrescente-se que Sá-Carneiro não foi, em nada do que escreveu (ou viveu), aquilo que usualmente se entende por 'escolar'. No que diz respeito ao contexto modernista e ao complexo multifacetado estético que o compõe, pode se dizer que o poeta participa de toda a sua variedade e variação, aproximando-se de cada uma destas facetas sem ser propriamente nenhuma delas. Por outras palavras, uma das especificidades mais importantes da sua estética consiste numa clara heterodoxia relativamente a qualquer tipo de ordem ou regra que surja do exterior. É o próprio poeta quem reconhece em si este glorioso traço do modernismo português que consiste em se afirmar independentemente de quaisquer dogmatismos:

\footnotetext{
${ }^{53}$ Idem, ibidem, 1978: 43

${ }^{54}$ Idem, ibidem.
} 
Dispam-se o Oiro e o Luar,

Rasguem as minhas togas de astros

Quebrem os ónix e alabastros

Do meu não me querer igualar. ${ }^{55}$

${ }^{55}$ Idem, ibidem: 151. 


\section{Mário de Sá-Carneiro e sua singularidade}

No capítulo anterior, a análise da relação de Mário de Sá-Carneiro com Orpheu e o contexto modernista em que a sua criatividade se iniciou e desenvolveu, conduziu aproveitamento ético das teorias de Fernando Pessoa. O levantamento e ordenação das principais concepções e opções estéticas singulares de Sá-Carneiro, bem como a indicação de algumas sugestões metafísicas encontradas na sua estética, implicam também em semelhante aproveitamento, para além da análise da sua correspondência e obra.

Isso se justifica não só pela índole poética de Sá-Carneiro, alheia a ordem ou sistematização lógicas, como ainda pela forte influência que Pessoa exercia sobre o amigo, a qual é percebida nas Cartas, através de explícitas referências à posição de mestre que Pessoa, admirado por Sá-Carneiro, detinha. Apesar da delimitação desta influência não poder ser totalmente objetivada, é com base na leitura crítica d'A Confissão de Lúcio e seus textos que se tentará distinguir e explicitar a parte criativa dessa assimilação.

O modo de ser psíquico e literário de Sá-Carneiro, dispersivo e fragmentário, são nele indestrinçáveis, fato que foi explicitado por Fernando Pessoa:

"Génio na arte, não teve Sá-Carneiro nem alegria nem felicidade nesta vida.

Só a arte que fez ou que sentiu, por instantes o turbou de consolação. São assim os que os Deuses fadaram seus. Nem o amor os quer, nem a esperança os busca, nem a glória os acolhe. Ou morrem jovens, ou a si mesmos sobrevivem, Íncolas da incompreensão ou da indiferença. Este morreu jovem, porque os Deuses Ihe tiveram muito amor.

Mas para Sá-Carneiro, génio não só da arte mas da inovação dela, juntou- 
se, à indiferença que circunda os génios, o escárnio que persegue os inovadores, profetas, (...) de verdades que todos têm por mentira."56.

Deste modo, vida e arte podem se confundir em Sá-Carneiro, o que consecutivamente expressa uma trágica ambigüidade da sua vida: a procura incessante e torturada de uma unidade essencial destinada a ficar aquém - na dor de ser-quase, dor sem fim $^{57}$-, ou seja, perante a vacuidade estéril que o impulso (ou propósito?) de se perder em si mesmo, essa experiência de dissociação a que permanentemente se entrega, acabou por na sua alma gerar:

“(...) mistério: evidenciando-se, também, a minha alma se desensombraria. Era ele só a minha angústia. E hoje - meu Deus! - a tortura volvera-se em quebranto; o segredo que velava a minha desconhecida só me atraía hoje, só me embriagava de champanhe - era a beleza única da minha existência.

Daí por diante seria eu próprio a esforçar-me por que ele permanecesse, impedindo que luz alguma o viesse iluminar. E quando desabasse, a minha dor seria infinita. Mais: se ele soçobrasse, apesar de tudo, numa ilusão, talvez eu ainda o fizesse prosseguir!

O meu espírito adaptara-se ao mistério - e esse mistério ia ser a armadura, a chama e o rastro de ouro da minha vida..." 58

"A prova de que o meu espírito andava doente, muito doente, tive-a uma noite dessas - uma noite chuvosa de dezembro...

Narciso do Amaral decidira-se enfim a executar-nos o seu concertante Além, que terminara há muitas semanas e que até hoje só ele conhecia.

Sentou-se ao piano. Os seus dedos feriram as teclas...

\footnotetext{
${ }^{56}$ PESSOA, 1946: 119-120

${ }^{57}$ SÁ-CARNEIRO, 1978: 69. In: Poesias

${ }^{58}$ Idem, ibidem, 1991: 76-77
} 
Automaticamente os meus olhos se tinham fixado na esposa de Ricardo, que se assentara num fauteuil ao fundo da casa, em um recanto, de maneira que só eu a podia ver olhando ao mesmo tempo para o pianista.

Longe dela, em pé, na outra extremidade da sala, permanecia o poeta.

E então, pouco a pouco, à medida que a música aumentava de maravilha, eu vi — sim, na realidade vi! — a figura de Marta dissipar-se, esbater-se, som a som, lentamente, até que desapareceu por completo. Em face dos meus olhos abismados eu só tinha agora o "fauteuil" vazio...

Fui de súbito acordado da miragem pelos aplausos dos auditores que a música genial transportara, fizera fremir, quase delirar...

E, velada, a voz de Ricardo alteou-se:

- Nunca vibrei sensações mais intensas do que perante esta música admirável. Não se pode exceder a emoção angustiante, perturbadora, que ela suscita. São véus rasgados sobre o Além - o que a sua harmonia soçobra... Tive a impressão de que tudo quanto me constitui em alma, se precisou condensar para a estremecer - se reuniu dentro de mim, ansiosamente, em um globo de luz...

Calou-se. Olhei...

Marta regressara. Erguia-se do fauteuil nesse instante..."

Em suas obras, que parecem surgir como "a confissão de que a vida não basta", tal universo, povoado de inesgotáveis sonhos e quimeras, não pode deixar de ser considerado. Não somente por ele anunciar com grande antecipação a prática surrealista, transpondo-a e utilizando-a conscientemente em termos estéticos, mas também dada a sua literatura ser fora da norma, excepcional - este psiquismo ampliado, incoerente e abissal modela profundamente a sua criatividade, produzindo uma das especificidades da

\footnotetext{
${ }^{59}$ Idem, ibidem: 68-69
} 
sua obra: a desmesura, o exagero, o caráter excessivo e intenso que a percorre.

Exacerbar, exagerar, exceder, ultrapassar são expressões que se adéquam especialmente à questão estética de Mário de Sá-Carneiro, não só em termos mais amplos de uma certa atmosfera e tom específicos, mas relativamente à diversidade de facetas que a compõem e que surgem integradas nestes dois últimos aspectos.

Por outro lado, nota-se ao longo das Cartas a Fernando Pessoa e da ficção poética como a questão da estética é importante para Sá-Carneiro, pela diversidade e freqüência das alusões que o poeta lhe faz. No entanto, produzidas, sobretudo por impulsos imaginativos, estas formulações refletem sua natureza predisposta a afirmar os antagonismos, sendo muitas vezes incoerentes, como o que relata sobre o projeto do conto "Pequeno elemento no caso Fabrício": "Trata-se de um homenzinho que de súbito aparece outro - em alma, claro: ele próprio concorda diante dum espelho que aquele que ele diz ser é louro e gordo: enquanto o espelho lhe reflete um magro e trigueiro "[ ${ }^{60}$. Além disto, a forma labiríntica e poética como são expostas, e o hibridismo que essencialmente as caracteriza, geram freqüentemente uma desorientação feita de perplexidade e de certa estranheza que a obra transmite por constantemente escapar, dificultando qualquer hipótese tranqüila de definição no campo das classificações literárias. De qualquer forma, a arte, a beleza, o ser-artista são "objetos principais", constantemente tematizados: não só as personagens em que se desmultiplica (ele se despedaça e se dispersa, pela fragmentação ou pela multiplicação) são sempre artistas hipervibráteis, como as inúmeras bizarrias relativas a essa sua condição invulgar que obsessivamente 'os' preocupam, e também toda a série de mágicos delírios e de teorias febris sobre estética que vão "entresonhando".

\footnotetext{
${ }^{60}$ SÁ-CARNEIRO, 1978: 281
} 
Assim, como que refletindo esse caso de desdobramento a que chama "Eu próprio o Outro", coexistem no poeta tendências diferentes na caracterização da arte literária e da índole artística ${ }^{61}$. Enquanto autor, o poeta defende determinadas posições que, por vezes, se mostram contrárias às que estão nas personagens das suas novelas $^{62}$. Afinal, a coexistência de princípios estéticos diversos em Sá-Carneiro vai ao encontro da tarefa que, segundo Pessoa, está reservada à literatura do século $X X$, ou seja, uma síntese entre duas ordens distintas de valores: "O século $X X$ encontrou diante de si, herdado do século que o precedeu, um problema fundamental - o da conciliação da Ordem, que é intelectual e impessoal, com as aquisições emotivas, e imaginativas dos tempos recentes. ${ }^{63}$.

Deste modo, por um lado, nota-se um certo intelectualismo derivado, em Pessoa, da influência do individualismo racionalista grego que Sá-Carneiro refere brevemente na correspondência entre ambos, mas não chegando a exercitá-lo. Para esta perspectiva, a função formalizadora da inteligência deve ser principal na expressão artística - "tornar a imaginação abstracta, tornar a emoção abstracta, é o caminho"64. Por outro lado, e mais relevante no contexto estético de Sá-Carneiro, a importância dada à fantasia absoluta e à vibração emocional.

\footnotetext{
${ }^{61}$ Semelhante referência aparece em Arthur Rimbaud, em carta a Paul Demeny de 15.05.1871, ao dizer que o poeta torna-se vidente através de um longo e estudado desregramento de todos os sentidos. Ele busca em si mesmo todas as formas de amor, de sofrimento, de loucura; prova todos os venenos:

“(...) Eu é um outro. Se o cobre acorda clarim, não é absolutamente sua culpa. Isso me parece evidente: assisto à eclosão de meu pensamento: eu o observo, eu o escuto: ataco com meu arco: a sinfonia rumoreja nas profundezas, ou vem à cena num relance. (...).

O poeta torna-se vidente através de um longo, imenso e estudado desregramento de todos os sentidos. Todas as formas de amor, de sofrimento, de loucura; ele busca a si mesmo, prova todos os venenos, para guardar apenas a quintessência. Inefável tortura em que é necessária toda a fé, toda a força sobre-humana, quando ele se torna entre todos o grande doente, o grande criminoso, o grande maldito - e o supremo Sábio! - Pois chega ao desconhecido! Ele cultivou sua alma, já rica, mais do que qualquer outro! Ele chega ao desconhecido, e ainda que, enlouquecido, acabe perdendo a inteligência de suas visões, ele as viu!" (RIMBAUD: 1950, 202. Trad. minha).

${ }^{62}$ SÁ-CARNEIRO, 1980: 60

${ }^{63}$ PESSOA, 1973: 147

${ }^{64}$ Idem, ibidem.
} 
Em uma consideração global dos textos de Sá-Carneiro revela-se, de imediato, a exaltação sensorial que os percorre, sugerindo-a e reforçando o papel de uma emotividade intensa na expressão poética - e, por isso, próxima do sensacionismo. Abaixo, alguns exemplos extraídos da correspondência e da obra elucidam melhor tal questão.

Os verdadeiros artistas, para Sá-Carneiro, devem ser capazes de pensar a beleza, de a descer (vivê-la por sensações), distinguindo-se dos meios-artistas ou daqueles que apenas manufaturam beleza, sendo incapazes de a pensar. Esta concepção do artista aparece juntamente com uma outra idéia que identifica a Arte, na sua expressão máxima, com o Pensamento:

"Como se a intelectualidade se não pudesse conter na arte! (...) a arte (...) deve servir o pensamento, fazendo-o vibrar, resplandecer - ser luz, além de espírito. (...) E quando por vezes é grande arte e não é pensamento - o arrepio que uma obra plástica de maravilha pode provocar naquele que a contempla. Ah! como eu amo a Idéia!" ${ }^{65}$.

Esta afirmação surge num contexto de crítica a Mário Beirão, o qual acusa Pessoa de intelectualizar tudo o que escreve. Daí que a veemência de Sá-Carneiro se possa explicar mais como defesa do seu amigo, contra a incompreensão do verdadeiro sentido da sua poesia, não significando uma preferência consciente por uma arte predominantemente intelectual. Contrastando com esta posição, encontra-se: "a Arte timbra-se para os nervos a vibrarem e não para a inteligência medi-la em lucidez ${ }^{\text {,66 }}$. A contradição é, no entanto, apenas aparente: a exigência de uma arte intelectual não

\footnotetext{
${ }^{65}$ SÁ-CARNEIRO, 1978, 130. In: Cartas

${ }^{66}$ Idem, ibidem.
} 
pretende propriamente um acréscimo de reflexão em torno da obra plástica, ou a sua realização obedecendo ao predomínio da forma e das idéias, mas uma ampliação da emoção e expressão estéticas à maneira vibrante e sensual dos sensacionistas ${ }^{67}$. É isto que significa para o poeta suscitar o pensamento, fazê-lo vibrar, resplandecer, como aliás ele mesmo indica: “(...) As minhas obras são executadas a sons e idéias - a sugestões de idéias (...). Os meus poemas são para se interpretarem com todos os sentidos... Têm cor, têm som e aroma - terão gosto, quem sabe..."68.

Aparecem igualmente nas Cartas repetidas afirmações de Sá-Carneiro sobre a superioridade do poeta ou do artista face ao crítico ${ }^{69}$. Contudo, é de supor que também estas sejam mais opiniões circunstanciais. Por um lado, Sá-Carneiro sempre tentou persuadir Fernando Pessoa a, não abandonando de todo o trabalho crítico, fazer aparecer o poeta. Por outro lado, nada nos informa que Sá-Carneiro pudesse conceber uma oposição absoluta - e, nesse sentido, necessariamente ingênua e artificiosa - entre imaginação e sensibilidade, enquanto capacidades usualmente consideradas poéticas, e a inteligência e lucidez, em princípio exigidas à crítica.

O que parece ser indubitavelmente autêntico em Mário de Sá-Carneiro é a radicalidade da sua opção pela arte, o caráter de absoluto que sempre pôs na busca da sua própria expressão poética, sabendo sentir e corresponder ao apelo integral da Arte, aceitando ir até ao $\mathrm{fim}^{70}$, ou seja, ousando "correr o risco de incarnar a imaginação na vida", ao ponto de "converter toda a realidade em realidade poética"71.

\footnotetext{
67 Conceito de complexificação do sensacionismo: a sensação vale-se do pensamento analítico para ampliar-se, complexificar-se.

${ }^{68}$ SÁ-CARNEIRO, 1980: 186

${ }^{69}$ Idem, ibidem: 36, 63, 88, 129 e 133. In: Cartas

${ }^{70}$ Idem, ibidem, 130. In: Cartas

${ }^{71}$ LOURENÇO, 1974: 57-58
} 
Considerando-se que Sá-Carneiro relata a Pessoa sobre o processo de aproveitamento do seu próprio 'material' psíquico ser unicamente em função da literatura, pode-se ter uma idéia não só da consciência que tinha de si enquanto escritor ser plenamente elaborada e lúcida, mas também de quanto o seu grau de dedicação à arte ter sido incomum e ainda "autêntico de verdade"; aliás, para a geração de Orpheu é extremamente importante a "aceitação sem limites da seriedade da poesia, ou, se se prefere, da poesia como realidade absoluta" ${ }^{\prime 2}$.

"É curiosa esta função do cérebro-escritor. De tudo quanto em si descobre e pensa faz novelas ou poesias. Mais feliz que os outros para quem as horas de meditação sobre si próprios são horas perdidas. Para nós elas são ganhas. Menos nobres só. O desperdício é nobre. O interesse vil. E o artista é mais interesseiro do que o judeu. Tudo - cenários, pensamentos. dores, alegrias - se Ihe transforma em matéria de arte! ... Ganha sempre..". ${ }^{73}$

Mas, apesar de toda a série de incoerências duvidosas quanto à presença ou ausência das idéias em literatura, Sá-Carneiro parece optar pelo equilíbrio: "Não trabalhar só com idéias - trabalhar também com o som das frases. Não escrever só edificar (...), esculpir beleza plástica nas frases. ${ }^{, 74}$.

No entanto, é a inextricável ligação entre os diferentes elementos que compõem este aparente equilíbrio que o torna problemático. Tal acontece primeiramente, pelo conceito de idéia - um espírito velado - que o poeta, com a sua Imaginação Nova, exibe, como ao citar que os versos aparecem "ligados entre si por ligações fluídas, por elementos gasosos nunca a sólido, por idéias sucessivas"75, acrescentando: "Serei pouco

\footnotetext{
${ }^{72}$ Idem, ibidem, 1982: 57-58

${ }^{73}$ SÁ-CARNEIRO, 1978: 54. In: Cartas. Ressalva: sabe-se que esse aproveitamento não permite inferir a vida da obra, pois há entre elas uma dose (incomensurável) de estilização.

${ }^{74}$ Idem, ibidem 72. In: Cartas

${ }^{75}$ Idem, ibidem, 1980: 186
} 
lúcido. Entanto como exprimir-me de outra maneira?"176. Na prosa ocorre mesmo efeito: "Fui pouco a pouco distinguindo os objetos... E, de súbito, sem saber como, num rodopio nevoento, encontrei-me sentado em um sofá, conversando com o poeta e a sua companheira...."77.

Em termos de expressão estética, sentir é, para Sá-Carneiro, superior a compreender. É o poeta quem o afirma na sua forma direta e sugestiva:

"Há tão pouco que compreender no que escrevo - nisto tudo... Digo: 'A imagem da minha vida estampa-se-me como uma série de losangos de zinco'. É só isto. Não procurem nada aqui - não há nada a perceber. (...) Nem posso exprimir doutra maneira, com maior clareza, porque é assim assim mesmo.

Mas por o saber sentir, um pouco de ignorado me penetra.. ${ }^{, 78}$.

A obra de Sá-Carneiro não é "uma simples realização escrita", pois as palavras valem não tanto pelo que significam, mas especialmente pelo seu caráter simbólico, evocatório e mágico. Por outro lado, este novo poetar testemunha o seu poder de invenção integral ao procurar "(...) forçar a linguagem a ultrapassar os seus recursos 'naturais' de significação para a converter em coisa significativa de uma matéria e matéria por sua vez de uma nova significação. A palavra quer ganhar o estatuto de ópera música, plástica e libreto"80. A beleza plástica definida como labirinto, emanharamento, é conseguida através de formas ondeantes e de motivos curvos e contorcidos, como coisas emaranhadas, infinitas, fantásticas ${ }^{81}$, surgindo projetada como uma descrição sonora e "pintada" e servindo as palavras e as idéias essencialmente para dar a visão plástica e a

\footnotetext{
${ }^{76}$ Idem, ibidem, 1980: 186

${ }^{77}$ Idem, ibidem, 1991: 60

${ }^{78}$ Idem, ibidem, 1980: 62

${ }^{79}$ Idem, ibidem, 1980: 186

${ }^{80}$ LOURENÇO, 1974: 65

${ }^{81}$ SÁ-CARNEIRO, 1978: 72. In: Cartas
} 
sensação.

Contudo, estes elementos de inspiração claramente simbolista (ritmo e harmonia), tão importantes para a sugestão, aparecem ainda metamorfoseados pela associação à idéia do já visto - recorrente em passagens elucidativas e com hibridismo ${ }^{82}$ -, a qual é outra presença recorrente na obra de Sá-Carneiro ${ }^{83}$ :

“Enfim, para me entender melhor: esta sensação é semelhante, ainda que de sentido contrário, a uma outra em que provavelmente ouviu falar - que talvez mesmo conheça - a do já visto. Nunca lhe sucedeu ter visitado pela primeira vez uma terra, um cenário, e - numa reminiscência longínqua, vaga, perturbante chegar-lhe a lembrança de que, não sabe quando nem onde, já esteve naquela terra, já contemplou aquele cenário?..."

Assim se gera uma nova Arte, fluída, gasosa, volátil, correspondente às formas aéreas, as quais contribuem para criar uma insondável e imponderável atmosfera em que "sons interseccionados, planos cortados, (...) idéias inflectidas, súbitas divergências... [onde] Tudo se trespassará, se esgueirará, perpetuamente variável, ondulante (...),85, produzindo um efeito de movimento através do qual, é possível, por exemplo, compreender o Ar visionando

“(..) gomos de ar que se entrechocavam e soçobravam em catadupas, vértices esbatidos de luz, calotes de cor, planos que ora volteavam ora se detinham, harmonizando-se bizarramente, e eram assim com as coisas que sustentavam ou traspassavam uma beleza nova

\footnotetext{
82 mistura de paulismo, interseccionismo, futurismo, sensacionismo e outros 'ismos'. (Vide Cap. 2 Estética modernista na Revista Orpheu).

${ }^{83}$ SÁ-CARNEIRO, 1978: 95. In: Cartas

${ }^{84}$ Idem, ibidem, 1991: 42

${ }^{85}$ Idem, ibidem, 1980: 189
} 


$$
\text { talvez (...)." }{ }^{n 6} \text {. }
$$

A esta deformação anárquica e extra-subjetiva da própria atmosfera acrescenta-se, ao mesmo tempo e favorecido pela desconexão aflitiva, o "destrambelhamento", o elemento absurdo imiscuído de forma mais ou menos sutil ao pouco que resta de lógico, transtornando por completo esse ambiente de mobilidade, onde uma excitação zebrante, rangente, desconjuntada e emersa ${ }^{87}$ era já a regra, e dotando-o dessa completa "Irrealidade anil"88.

Fora esta importante "experiência do irrealismo" em Sá-Carneiro, vale a pena salientar como o poeta realiza um efeito muito semelhante ao "consciente e voluntário desregramento sensorial" ${ }^{\prime 29}$, e simultaneamente como este surge ampliado nessa procura de um além-sentidos que supera largamente os "limites da razão", situando-se indefinível e inexplicavelmente para lá da consciência e atingindo "os auges da dispersão". Ao abordar suas obras esquivas, extáticas de ouro, ungidas de Incerto, leoninas na ânsia ${ }^{90}$, o poeta escreve:

"Nas minhas ânsias de segredo tenho-me esforçado, (...) para que os meus sentidos vibrem diversamente: desengonçadamente, noutras direcções de crispado - dando-me assim, em vislumbres, uma ilusão intranqüila a desconhecido." 91.

De um modo geral as opções estéticas de Sá-Carneiro mostram-se ainda marcadas por todo aquele conjunto de 'ismos' que foram teorizados por Pessoa e basicamente caracterizaram os modernistas de seu grupo de convívio: sensibilidades

\footnotetext{
${ }^{86}$ Idem, ibidem: 128

${ }^{87}$ Idem, ibidem: 175

${ }^{88}$ Idem, ibidem: 128

${ }^{89}$ Idem, ibidem: 132

${ }^{90}$ Idem, ibidem: 277

${ }^{91}$ Idem, ibidem: 59
} 
superiormente requintadas e fortemente individualistas, determinadamente anti-sociais e anti-sociáveis, cultivando acima de tudo a diferença e a exceção e professando um arrogante e assumido aristocratismo de tonalidade fortemente decadente que os conduz ao elitismo em arte. Em Pessoa, o elitismo apresenta-se com ressonâncias nitzscheanas $^{92}$ - e dimensão polêmica ${ }^{93}$ - afirmando-se sob a forma de um preceito teórico, com a força de um imperativo ético, e destinando-se a todo o artista moderno e consciente da sua missão, a qual, além da exigência de uma disponibilidade total para a realização da sua arte, deveria consistir, precisamente, numa categórica oposição à plebeização das elites. É que "hoje, mais que nunca, se sofre a própria grandeza. As plebes de todas as classes cobrem, como uma maré morta, as ruínas do que foi grande e os alicerces desertos do que poderia sê-lo,94.

Aliás, Orpheu apresentara-se ao público exatamente como sendo um "exílio de temperamentos de arte que a querem como a um segredo ou tormento", correspondendo a um ideal esotérico, tendo o princípio aristocrático como critério estético explícito e a estética em si mesma como a opção por excelência ${ }^{95}$. Valorizando exclusivamente o raro e o insólito e contrapondo-se orgulhosamente à lepidopteria nacional, os órficos definiam a sua estética de forma tão extravagante quanto enigmática, como: “(...) ter o aplauso de lepidópteros e democráticos (...) é o pior que nos pode

\footnotetext{
${ }^{92}$ Segundo Nietzsche, a história da humanidade está vinculada a concepção de um eterno retorno, ou seja, tudo voltará a repetir-se em um novo ciclo. Para ele, a cultura ocidental depois de uma fase de apogeu, desde Sócrates, entrara numa longa fase de decadência que a conduziu ao Niilismo, marcada pela ausência de valores, terminando no indiferentismo. Neste percurso os valores superiores foram sendo substituídos pelos valores dos escravos, difundidos pelo Cristianismo e consagrados nos regimes democráticos e a ascensão das classes trabalhadoras. Estes falsos valores negam a vida em nome de ilusões (ideais) ou de uma vida futura. Deste modo, segundo o filósofo, a única possibilidade de sair desta fase de decadência é o homem transformar-se a si próprio, mediante a transmutação de todos os seus valores, encaminhando-se para aquilo que designou por Super-homem, a ser atingido apenas por uma pequena elite.

${ }^{3}$ Como por exemplo quando afirma: "A nossa arte é supremamente aristocrática (...) porque uma arte aristocrática se torna necessária neste outono da civilização européia, em que a democracia avança a tal ponto que, para de qualquer maneira reagir nos incumbe a nós artistas, pormos entre a elite e o povo aquela barreira que ele, o povo, nunca poderá transpôr - a barreira do requinte emotivo e da ideação transcendental, da sensação apurada até à subtileza (...)"(PESSOA, 1973: 158).

${ }^{94}$ PESSOA, 1946: 120

${ }^{95}$ Orpheu; s/d: 11
} 
suceder" ou então "Veja o que sucedeu às bicicletas: artigo de luxo que, começando a ser empregado pelos democráticos, desapareceu da via pública como sport elegante. A pior recomendação dum produto de luxo é o seu consumo popular"96.

Nos textos de Pessoa, em sutis "fingimentos", blagues e em tom paradoxal (com que muitas vezes punha desiludidamente ironia no ter afinal razão), o que se torna realmente difícil é escolher, entre tantos exemplos, até porque o poeta faz "todos os esforços para não ser a mesma coisa durante três minutos a fio por ser má higiene estética,97. Tal atitude é natural, pois "não há nenhum instinto do sensato em moderna literatura, ${ }^{98}$, circunstância que não deixava de refletir-se inteiramente em Orpheu ${ }^{99}$.

Estas e outras idéias sutis não invalidam nem a seriedade dos propósitos artísticos modernistas nem a existência de uma dimensão autenticamente pensante envolvendo esta arte. Pelo contrário, elas são partes integrantes da missão agitadora a que os novos poetas conscientemente se atribuem. Note-se como este caráter revolucionário de Orpheu se revela a um nível estrutural, ou seja, para além dos novos sentidos poéticos que instauram, no plano espiritual de uma transformação profunda das mentalidades, criação de novas "visões da realidade". Assim, entende-se que "a finalidade da arte é simplesmente aumentar a auto-consciência humana" tendo por isso "o dever de se tornar cada vez mais consciente" ${ }^{\text {"100, }}$, constituindo-se, deste modo, uma revolução estética "polivalente" fundamentada de forma filosófica, embora muito pouco sistemática. Desta perspectiva ampla da função do ser-artista decorre que não pode haver

“(...) para a arte critério exterior. O fim da arte não é ser compreensível,

\footnotetext{
${ }^{96}$ SÁ-CARNEIRO, 1979: 83-84

${ }_{97}$ PESSOA, s/d: 139 . Vide nota 7.

${ }^{98}$ PESSOA, s/d: 155

${ }^{99}$ Pessoa afirma: "o paradoxo não é meu: sou eu" (PESSOA, 1946: 297-299).

${ }^{100}$ PESSOA, s/d: 186, 160, 162
} 
porque a arte não é a propaganda política ou moral. (...) A indiferença para com a Pátria, para com a Religião, para com as chamadas virtudes cívicas e os apetrechos mentais do instinto gregário não são úteis, mas absolutamente deveres do Artista. Se isto é amoral, a culpa é da Natureza, que o mandou criar beleza e não pregar a alguém."101.

Surge, pois, como inquestionável que uma noção da gravidade e do mistério da Vida perpassa a alma de Orpheu; mas para além desta fundamental idéia metafísica autenticadora da sua poética, esta geração continha ainda em si “(..) uma riqueza de sensação, uma complexidade de emoção, uma tenuidade e intercruzamento de vibração intelectual que nenhuma outra geração nasceu possuindo."102. Abaixo segue como se reflete e transfigura este conjunto de traços que compõem a consciência modernista, nas motivações e tensões que estruturam certa atmosfera típica das facetas estéticas de SáCarneiro.

Várias vezes aparece registrada no diálogo entre os dois poetas a mesma apologia decadente de certas complicações e estranhezas mórbidas, que surgem apontadas como sinal distintivo da sua arte e indício seguro da sua superioridade intelectual e artística. Dir-se-á que o máximo funcionamento poético está, para SáCarneiro e Pessoa, estreitamente ligado à infelicidade e a tudo quanto de doloroso e/ou doentio com que ela se relaciona. Ao mesmo tempo, a tendência, presente em ambos, para uma tendência introspectiva e melancólica, parece constituir o motivo inibidor de uma entrega espontânea a sentimentos ditos normais - como a leveza da alegria e do entusiasmo, sendo, em compensação, produtiva em termos estéticos.

\footnotetext{
${ }^{101}$ Idem, ibidem: 186, 160, 162

102 Idem, ibidem, 163-164
} 
Como inovação modernista na poesia portuguesa surge como campo temático o naturalismo da alma humana ${ }^{103}$, entendendo-se por tal a expressão desinibida e aprofundada dos meandros do psiquismo humano. Mário de Sá-Carneiro e Fernando Pessoa teriam ainda descrito os aspectos "feios e mórbidos" do inconsciente humano, não tanto "por serem fascinantes num sentido decadentista, mas simplesmente por serem reais na sua banalidade, pouco ou nada fascinante"104, como na fala de Lúcio, de A Confissão de Lúcio: “ao possuí-la [Marta] eu era todo medo - medo inquieto e agonia: agonia de ascensão, medo raiado de azul; entanto morte e pavor"105. Mas, para além disto, a extrema novidade dos dois poetas evidencia-se na circunstância de a sua imaginação poética se exercer sobre aspectos vulgares ou quotidianos, sem contudo não perder em nada a rara qualidade do seu poetar, ou seja,

\begin{abstract}
“com imagens triviais e mesmo grosseiras realizam a mais insólita das alquimias e instituem uma profundidade metafísica que não se concebia senão ligada a elementos 'nobres' ou a um 'tom' igualmente 'nobre' corno é o caso de Antero ou Teixeira de Pascoaes."106.
\end{abstract}

Sobre a aflição, Sá-Carneiro cita que “(..) numa grande angústia, às vezes, pode até um artista ir buscar, ainda que dolorosamente, material e vontade para uma obra de gênio. A dor, quanto a mim, pode ser fecunda."107.

$\mathrm{Na}$ verdade, a disponibilidade a um experienciar efetivo da angústia fundamental afirma-se em Sá-Carneiro como aceitação espontânea do risco da instabilidade permanente, na atitude de constante exposição de si que constitui afinal a coragem de Ser, respondendo ao apelo exigente, pelo qual a Dor reivindica a exploração

\footnotetext{
${ }^{103}$ WOLL, 1959: 93

104 Idem, ibidem: 93

${ }^{105}$ SÁ-CARNEIRO, 1991: 84

${ }^{106}$ LOURENÇO, 1982: 157-159

${ }^{107}$ SÁ-CARNEIRO, 1978: 93. In: Cartas
} 
dos segredos e tormentos. É que "a angústia do audacioso" ao ser contraposta à simples alegria ou ao fluir fácil e confiante de sentimentos tranqüilizadores, situa-se além de tais oposições mantendo uma ligação com esse "horizonte de todos os horizontes" que é, como diz Sá-Carneiro, álcool que nos esvai em lume que nos arde. O seguinte trecho, apesar de longo, mostra $n^{\prime} A$ Confissão de Lúcio, em relação à amizade predestinada ${ }^{108}$ entre Ricardo de Loureiro e Lúcio Vaz, a importante confissão deste:

"As minhas conversas com Ricardo - pormenor interessante - foram logo, desde o início, bem mais conversas de alma, do que simples conversas de intelectuais.

Pela primeira vez eu encontrara efetivamente alguém que sabia descer um pouco aos recantos ignorados do meu espírito - os mais sensíveis, os mais dolorosos para mim. E com ele o mesmo acontecera - havia de mo contar mais tarde.

Não éramos felizes — oh! Não... As nossas vidas passavam torturadas de ânsias, e incompreensões, de agonias de sombra...

Subíramos mais alto: delirávamos sobre a vida. Podíamo-nos embriagar de orgulho, se quiséssemos - mas sofríamos tanto... tanto... O nosso único refúgio era nas nossas obras.

Pintando-me a sua angústia, Ricardo de Loureiro fazia perturbadoras confidências, tinha imagens estranhas.

— Ah! meu caro Lúcio, acredite me! Nada me encanta já; tudo me aborrece, me nauseia. Os meus próprios raros entusiasmos, se me lembro deles, logo se me esvaem - pois, ao medi-los, encontro-os tão mesquinhos, tão de pacotilha... Quer saber? Outrora, à noite, no meu leito, antes de dormir, eu punha-me a divagar. E era feliz por momentos, entressonhando a glória, o amor, os êxtases... Mas hoje já não sei com que sonhos me robustecer.

\footnotetext{
${ }^{108}$ A "amizade de alma" é recorrente na prosa poética de Sá-Carneiro, podendo ser uma transposição e estilização da sua relação com Fernando Pessoa.
} 
Acastelei os maiores... eles próprios me fartaram: são sempre os mesmos — e é impossível achar outros... Depois, não me saciam apenas as coisas que possuo - aborrecem-me também as que não tenho, porque, na vida como nos sonhos, são sempre as mesmas. De resto, se às vezes posso sofrer por não possuir certas coisas que ainda não conheço inteiramente, a verdade é que, descendo-me melhor, logo averiguo isto: Meu Deus, se as tivera, ainda maior seria a minha dor, o meu tédio. De forma que gastar tempo é hoje o único fim da minha existência deserta. Se viajo, se escrevo - se vivo, numa palavra, creia-me: é só para consumir instantes. Mas dentro em pouco - já o pressinto - isto mesmo me saciará. E que fazer então? Não sei... não sei... Ah! Que amargura infinita..."109.

Surge recorrentemente nas obras de Sá-Carneiro essa valorização da fecundidade da dor e de certas experiências existenciais limite, onde se instala um desconforto estagnado e acontecem lágrimas e gritos, no sentido da sua utilização estética. Angústia, náusea, horror, pavor, martírio são palavras várias vezes utilizadas ao longo das suas páginas, como se a sua repetição pudesse talvez suprir a insuficiência que elas denotam, ao tentar expressar todo o caótico, labiríntico, excessivo e aterrador tumulto que preenche o ampliado mundo interior do poeta. Neste acontece ainda, freqüentemente, um perturbante e incomum 'interseccionismo' pelo qual sensações de dor física e de dor psíquica se entrecruzam em desregrado e doloroso desvario:

“- O meu sofrimento moral, ainda que sem razões, tem aumentado tanto, tanto, estes últimos dias, que eu hoje sinto a minha alma fisicamente. Ah! é horrível! A minha alma não se angustia apenas, a minha alma sangra. As dores morais transformam-se-me em verdadeiras dores físicas, em dores horríveis, que eu sinto materialmente - não no meu corpo mas no meu 
espírito. É muito difícil, concordo, fazer compreender isto a alguém. (...) a minha pobre alma (...) Endureceu-me toda, toda! secou, ancilosou-se-me; de forma que movê-la - isto é: pensar - me faz hoje sofrer terríveis dores. E quanto mais a alma me endurece mais eu tenho ânsia de pensar! Um turbilhão de idéias - loucas idéias! - me silva a desconjuntá-la, a arrepanhála, a rasgá-la, num martírio alucinante! (...)."110.

As personagens que cultivam a estética e que 'habitam' a sua obra destacam-se "pela intensidade excessiva do seu gênio, as complicações do seu espírito", as quais se chegam a manifestar até exteriormente, na "estranheza do seu porte". Além disto, exprimem-se quase sempre "inquietadoramente: em maravilhas (...) e destrambelhos reais"111. Esta mistura de singularidade ou complexidade e requinte típica dessas personagens geniais, de alma ampla e intensa, as quais para Sá-Carneiro constitui a essência do ser-artista e que, embora seja motivo de orgulho dada a marca de superioridade nela implícita, é surpreendentemente a principal razão de sofrimento pelo reverso desolado e nostálgico que contém, de inadaptação à claridade quotidiana, de exclusão da vida útil:

"Porque afinal essa sua vida — 'a vida de todos os dias' — é a única que eu amo. Simplesmente não a posso existir... E orgulho-me tanto de não a poder viver .. orgulho-me tanto de não ser feliz... Cá estamos: a maldita literatura...

E, depois de uma breve pausa:

- Noutros tempos, em Lisboa, um meu companheiro íntimo, hoje já morto, alma ampla e intensa de artista requintado - admirava-se de me ver acamaradar com certas criaturas inferiores. É que essas andavam na vida, e eu aprazia-me com elas numa ilusão. As minhas eternas incoerências!

\footnotetext{
110 Idem, ibidem: 45-46

${ }^{111}$ Idem, ibidem, 1980: 177-178
} 
Vocês, os verdadeiros artistas, as verdadeiras grandes almas - eu sei nunca saem, nem pretendem sair, do vosso círculo de ouro - nunca lhes vêm desejos de baixar à vida. É essa a vossa dignidade. E fazem bem. São muito mais felizes... Pois eu sofro duplamente, porque vivo no mesmo círculo dourado e, entretanto, sei-me agitar cá embaixo..." 112.

Esta oposição sem tréguas nem possível mediador, entre a vida simples e a vida artística, pela qual a primeira é completamente desqualificada face à segunda, e sobretudo a rebuscada ambivalência com que é vivida literariamente, é tópico constante em sua poética, manifestando-se no dualismo: sedução pela facilidade quente e cariciosa da existência comum e, em simultâneo, aversão à banalidade da maioria que “(...) se contenta com poucas ânsias, poucos desejos espirituais, pouca alma... (...) com as obscenidades lantejouladas de qualquer baixo-revisteiro sem gramática..." ${ }^{113}$.

Esta concepção dualista reaparece ainda a propósito da noção de Beleza, a qual, para Sá-Carneiro, emerge como algo de extraordinário e imaterial, entidade metafísica, valorizada pela idealização e pelo caráter distante, inacessível e inatingível, que esta impõe:

“(...)

Arranquem-me esta grandeza!

- Pra que me sonha a beleza,

Se a não posso transmigrar? ...

(...)

Porque eu reajo. A vida, a natureza,

Que são para o artista? Coisa alguma

O que devemos é saltar na bruma

\footnotetext{
112 Idem, ibidem: 48

113 Idem, ibidem: 50
} 
Correr no azul à busca da beleza.

$(\ldots)$

As grandes Horas! - vivê-las

A preço mesmo dum crime!

Só a beleza redime -

Sacrifícios são novelas." ${ }^{114}$.

Neste sentido, a Beleza surge relacionada com outras idéias, também esteticamente relevantes em Sá-Carneiro - as de Ideal, Perfeição e Infinito - revelando essa ânsia de ultrapassar, de se evadir do insuficiente real e, com ela, um imenso desejo de intensificar, de ampliar, abarcar "tudo de todas as maneiras"115.

"E solto meus olhos a enlouquecerem de Ar!

Oh! poder exaurir tudo quanto nele se incrusta,

Varar a sua Beleza - sem suporte, enfim!

Cantar o que ele revolve, e amolda, impregna,

Alastra e expande em vibrações:

Subtilizado, sucessivo - perpétuo ao Infinito! ..."116.

Por outro lado, coexiste no poeta essa outra ânsia de, sempre excedendose, sentir até à exaustão. Neste novo sentido, a beleza surge-Ihe associada a uma idéia sutil de medo, fazendo-o sofrer, numa necessidade sensual e absoluta, quase vital, de se ligar a tudo quanto seja indeterminado, desconhecido ou misterioso:

"De maneira que a realidade inquietante era esta: aquela mulher erguia-se aos meus olhos como se não tivesse passado - como se tivesse apenas um presente!

Em vão tentei expulsar do espírito as idéias afogueadas. Mais e mais cada

\footnotetext{
114 Idem, 1978: 60, 52 e 122. In: Poesias

115 PESSOA, 1986: 278. In: Obras Poéticas

116 SÁ-CARNEIRO, 1978: 171. In: Poesias
} 
noite elas se me enclavinhavam, focando-se hoje toda a minha agonia em desvendar o mistério." 117.

A ambivalência, "atração/ repulsão", orienta dinamicamente a relação de SáCarneiro com quase todas as fixações dominantes do seu universo estético, tanto como as anteriores citadas, como também no caso do Mistério, entidade irreal que subsiste na obra, como tema, atmosfera, tom narrativo, e ainda como uma espécie de objeto de culto, de estranha veneração e bizarra idolatria, excessivas e em grande parte inexplicáveis ${ }^{118}$.

Lúcio Vaz, personagem d'A Confissão de Lúcio ao refletir sobre as "repugnâncias misteriosas" em face do "corpo admirável" de Marta, esclarece a duplicidade desta atração fatal pelo mistério e também a sua estreita ligação com outro eixo fixo, a sensualidade - intensamente pesada, perversa e exótica -, uma das motivações profundamente tensas em Sá-Carneiro que percorre toda a obra, exibindo por vezes o seu lado violentamente "bárbaro":

"Com efeito a sua carne de forma alguma me repugnava numa sensação de enjôo - a sua carne só me repugnava numa sensação de monstruosidade, de desconhecido: eu tinha nojo do seu corpo como sempre tive nojo dos epilépticos, dos loucos, dos feiticeiros, dos iluminados, dos reis, dos papas - da gente que o mistério grifou ..." ${ }^{119}$.

"Marta, porém, não gritou. Era muito natural que gritasse com a minha violência, pois a boca ficara-me até sabendo a sangue. Mas o certo é que não teve um queixume. Nem mesmo parecera notar essa carícia brutal...

\footnotetext{
${ }^{117}$ idem, 1991: 66-67

${ }^{118}$ vide trecho supracitado - SÁ-CARNEIRO, 1991: 66-67

${ }^{119}$ SÁ-CARNEIRO, 1991: 105
} 
De modo que, depois de ela sair, eu não pude recordar-me do meu beijo de fogo — foi-me impossível relembrá-lo numa estranha dúvida..."120.

Para Sá-Carneiro, a sensualidade é muito mais do que um motivo de análise ou um pretexto de reflexão, pois não se deve "(...) discutir o papel da voluptuosidade na arte, porque (...) a voluptuosidade é uma arte - e, talvez, a mais bela de todas "121, como diz a Americana de A Confissão de Lúcio. Ou seja, seu valor para Sá-Carneiro parece ser superior ao de outros temas e impulsos recorrentes na obra, surgindo o erotismo como uma espécie de substrato ativo que os envolve a todos, condicionando de forma preponderante e consciente toda a estética.

A natureza deste erotismo (a ser retomado posteriormente, visto seu importante valor) apresenta-se marcada pela mesma inquietação e ambigüidade que o poeta imprime a tudo quanto valoriza esteticamente e não é obviamente comum: irreais e irrealizáveis, estas voluptuosidades ignoradas e fulvas, espasmos supremos ${ }^{122}$ são declarados como constituindo uma verdadeira excitação sexual "- mas de desejos espiritualizados de beleza"123, uma vez que

"A 'natureza' é para a gente-sadia, a subgente normal... Nós, excessivos em Oiro, libertámo-nos dela. (...) aumentámo-la: démos-lhe uma alma, e só o seu espírito - o espírito que lhe criamos - nos suscita os desejos. Somos gente de Alma - projetamos alma a quanto admiramos, a quanto apetecemos..."124.

\footnotetext{
${ }^{120}$ Idem, ibidem: 102

${ }^{121}$ A Americana ainda acrescenta: "Porém, até hoje, raros a cultivaram nesse espírito. (...) digam-me: fremir em espasmos de aurora, em êxtases de chama, ruivos de ânsia - não será um prazer bem mais arrepiado, bem mais intenso, do que o vago calafrio de beleza que nos pode proporcionar uma tela genial, um poema de bronze?". (Idem, ibidem: 24).

${ }^{122}$ Idem, ibidem, 1978, 58. In: Cartas

${ }^{123}$ Idem, ibidem, 1991: 24

${ }^{124}$ Idem, ibidem, 1980: 329
} 
Deste conceito parte-se à exploração de novos sensualismos ${ }^{125}$ - mais anômalos, requintados e rebuscados - desde que, inconcretizáveis, se encontrem à altura de uma inesgotável intrínseca fantasia. Este ponto de vista fica evidente quando Sá-Carneiro, à busca da beleza, questiona:

"Onde encontrar beleza nos contactos do cio? Beleza... Mas haverá ridículo mais torpe?... Ah! o horror dos sexos - cartilagens imundas, crespas, hilariantes... E os suspiros da cópula; as contracções picarescas, suadas... Infâmia sem nome! Infâmia sem nome! Como resistir a tudo isto uma alma sensível?..."126.

Assim, o erotismo sensual de Sá-Carneiro aparece ao mesmo tempo marcado por uma acentuada idealização que o torna mais distinto e sutil, e também ainda mais incerto e perturbador: somente através de olhos refinados do poeta se pode presumir a carne inexistente através da qual se sonha esvair em ânsias, espasmos.

A mesma complexidade psíquica, ambivalente e excêntrica aparece ainda transposta na noção de uma beleza dolorosa, descrita enquanto algo de paradoxal e intenso que aparece ligado por laços dramáticos - dramatismo desmoralizado pela constante sugestão de inverosimilhança e acumulação de pormenores irrisórios ao longo das diferentes narrativas - ao horror, ao sangrento, a tudo quanto transtorna. A determinada artificialidade destas descrições em estilo contorcido manifesta um forte pendor expressionista.

Numa carta em que se refere à hipótese de conclusão de um projeto antigo (peça Irmãos - não concluída), Sá-Carneiro salienta como mais importante a criação da

\footnotetext{
${ }^{125}$ Idem, ibidem, 1991: 24

${ }^{126}$ Idem, ibidem, 1980: 286
} 
atmosfera torturada, perturbadora, e sobre uma possível substituição deste título, que induziria o leitor a "um caso meramente passional", por Um Estudo a Ruivo, acrescenta: “(...) ruivo simbolizando na sua cor indecisa, artificial e perturbadora as almas dos dois protagonistas (...) que se esquentam a imaginação numa hiperintelectualização e resvalam para o abismo."127.

Esta peça destinava-se a completar, juntamente com $A$ Confissão de Lúcio e Gentil Amor (esta tendo sido somente uma intenção, um projeto), um volume intitulado Perturbadoramente, o qual se resumiria ao estudo de determinada "circunstância psíquica" resultante incomum do desengano de um homem a quem é demonstrado que não cometeu o crime ${ }^{128}$ que pensava ter cometido. Não são o alívio e a paz o que Sá-Carneiro projeta fazer sentir ao seu personagem, o qual, pelo contrário, "mais desoladoramente torturado fica ao saber-se inocente. (...) E depois, sobretudo, vê-se despojado da beleza dolorosa, mas em todo o caso beleza - que tanta ânsia amarga suscitava na sua vida." ${ }^{299_{1}}$

Em um outro projeto intitulado $A$ Novela Romântica (também inacabado e anteriormente citado), que consistia de mesmo modo no tratamento de um "assunto rebuscado", Sá-Carneiro propõe-se a dar uma impressão extravagante, bizarra, mas perturbadora e bela, identificando "o exagero e a incoerência" como materiais que deveriam dar "a beleza ao conjunto" ${ }^{130}$. Ainda em um outro esboço referido nas Cartas, aparece a "estranha obsessão" de se "obter a alma da beleza", idéia semelhante à presente em Loucura (in A Grande Sombra) e o Fixador de Instantes, nos quais há a tentativa de fixar a beleza de uma mulher através de um crime terrivelmente violento,

\footnotetext{
${ }^{127}$ Idem, ibidem, 1978: 99. In: Cartas

${ }^{128} \mathrm{O}$ artista é visto numa perspectiva extra-moral (criminoso), aspecto pertencente ao ideário surrealista.

${ }^{129}$ SÁ-CARNEIRO, 1978: 98. In: Cartas

${ }^{130}$ Idem, ibidem, 1979: 64 e 68. In: Cartas
} 
surgindo a morte como única forma de poder viabilizar a consumação do amor por essa mulher - "Ele possui-a toda nesse corpo morto e pálido, lavado pelo luar" ${ }^{131}$.

É assim por paradoxos duplamente inquietantes que se desoculta este imaginário extra-ordinário de Sá-Carneiro, o qual é expresso através das apavorantes preferências descritas, das quais se destaca "(...) um além-gosto a doença, a monstruosidade (...)"132. Por um lado sobressai um propósito de guardar, quer a beleza, quer "as horas mais belas da nossa vida"133, elevado à principal "arte da sua vida", como aparece nos textos referidos e n'A Confissão de Lúcio. Por outro, desta fatal preocupação de reter, imobilizar - numa arte que paralelamente se vai expondo fluida, gasosa, sutil, ondulante - emerge uma mistura confusa, uma súbita idéia de crime cuja disforme violência se associa a certas imagens de uma sexualidade muito complicada, desembocando ambas num incomum e inestético ato de posse, só conseguido através de dolorosos êxtases arfados, incompreensíveis náuseas e, sobretudo, um "medo inquieto e agonia: agonia de ascensão, medo raiado de azul; entanto morte e pavor"134.

O desejo em Sá-Carneiro - complexo, exagerado, incoerente e dúplice como toda sua poética o expressa - é inseparável da beleza e do medo, os quais, por sua vez, contraditoriamente o ampliam e se ampliam, através de formas e forças de um encantamento infernal, mágico e temível, que uma aguçada e inventiva consciência do abismo por detrás de si própria ajuda a convocar: medo, sensualidade, loucura, morte produzindo paralelamente violência, destruição, instabilidade e perturbação. Este são alguns dos principais elementos da estética de Sá-Carneiro, em si mesmos também indestrinçáveis na sua excessiva "circularidade viciosa", no duplo sentido que a expressão possa ter.

\footnotetext{
${ }^{131}$ Idem, ibidem, 1978: 107. In: Cartas

132 Idem, ibidem, 1991: 84

${ }^{133}$ Idem, ibidem: 134

134 Idem, ibidem: 84
} 


\section{Uma leitura de A Confissão de Lúcio - Apresentação da narrativa}

A história da obra, centrada entre Lisboa e Paris, baseia-se na acusação de um crime cometido por Lúcio Vaz, de 23 anos, contra seu maior amigo, Ricardo de Loureiro, de apenas 27 anos, sendo a condenação àquele imposta por um período de dez anos de prisão, em Lisboa. Cumprida a pena em silêncio, sem expressar aversão ao período de perda de liberdade, vem após esse período através de sua confissão querer provar a sua inocência, pois acreditava que na época dos fatos sua defesa seria inútil ante as evidências obscuras e aparentemente ilógicas. Desse modo, Lúcio faz um relato de seu passado, interpretando a relação vivida com Ricardo e finalizando com a da vivência carcerária.

A Confissão de Lúcio é uma narrativa estruturada em uma abertura ou advertência $^{135}$ (como o narrador a chama) toda diagramada em itálico e em oito capítulos com subdivisões e pausas, estas marcadas através de espaçamento duplo, com uso de símbolos como asteriscos ou linhas pontilhadas.

$\mathrm{Na}$ abertura, o tipo normal (não itálico) demarca apenas algumas expressões $^{136}$, o que será retomado após estabelecer os níveis em que a ação se processa. Semelhante procedimento não estabelece uma separação entre o presente (tempo da enunciação) e o passado (tempo do enunciado), o qual fornecerá a matéria da narrativa extraída de um passado ainda mais remoto - anterior à prisão do protagonista (passado mais recente) -, pois usando simultaneamente os dois caracteres gráficos no último capítulo, dentro do que seria passado, o narrador situa-se no presente: "Acho-me tranqüilo - sem desejos, sem esperanças. Não me preocupa o

\footnotetext{
${ }^{135}$ Entre as páginas 15-17.

136 A saber: "cherchez la femme", "mortos-vivos", "desencantados", "Desses fatos, quem quiser, tire as conclusões" e "mesmo quando ela é inverossímil"
} 
futuro. O meu passado, ao revê-lo, surge-me como o passado de um outro. Permaneci, mas já não me sou"137.

Como a narrativa é estruturada na memória, a qual evoca coisas do passado muito provavelmente já dispersas, as pausas e asteriscos podem ser interpretados como estratégias para divisão temática e como passagem do tempo, como se o narrador estivesse formulando esquematizações. Já o mistério e o indefinido são confirmados e intensificados pelas linhas pontilhadas, ampliando ainda mais as dúvidas.

A principal estratégia da narrativa ou o que a aciona é o silêncio ou não total esclarecimento da morte de Ricardo de Loureiro por parte de Lúcio. Mas por que este misterioso crime não é esclarecido totalmente? Como se trata da época do modernismo português, a radicalização do novo e obscuro na obra é vinculada ao inverossímel e ao encobrimento da verdade, na tentativa dos órficos de mostrarem à sociedade portuguesa essa contradição: "Mas o que ainda uma vez, sob minha palavra de honra, afirmo é que só digo a verdade. Não importa que me acreditem, mas só digo a verdade - e mesmo quando ela é inverossímil ${ }^{\text {138. }}$.

Os órficos através de suas manifestações artísticas e literárias modernas estabelecem no início da séc. XX contrapontos à sociedade portuguesa, cuja visão advinha de literatos anteriores (como Ramalho Ortigão) e era baseada na de um Portugal irreal.

O romance psicológico faz com que o foco saia do real e vá para o misterioso, fazendo com que o universo do "eu" seja analisado de uma forma mais completa e densa, a provir de diferentes manifestações, como, por exemplo, as

\footnotetext{
${ }^{137}$ SÁ-CARNEIRO: 1991;135

${ }^{138}$ Idem, ibidem: 17
} 
sensações. O sujeito é transposto a uma dualidade paradoxal, em que dialoga constantemente com o seu interior. Passam, deste modo, a ser considerados os aspectos que envolvem as divergências de ordens psicológicas ou psíquicas relativas ao sobrenatural:

“ (...) O fantástico pode manifestar-se segundo dois esquemas diferentes e até opostos. Ou é a realidade material que se altera, se escapa às leis ordinárias do mundo, se torna um objecto monstruoso e como que saído de uma imaginação delirante, ou é uma simples imagem, um sonho, uma alucinação, que adquire subitamente caracteres reais, se torna um objecto ou um ser visível, palpável. Estes dois modos de fantástico poderiam receber os nomes de "fantástico exterior" (da percepção para o imaginário) e de "fantástico interior" (do imaginário para o percebido)"',139.

Deste modo, os órficos tentam chocar a sociedade, pela arte, ao manipular a dualidade - como mostrar o invisível no visível, e vice-versa, ou seja, trabalhando a obra tanto no nível da realidade de fora, quanto no da de dentro.

Esse paradoxo também está expresso nos diferentes caracteres gráficos utilizados ao longo da obra, tanto assegurando a inverossimilhança, exemplarmente no excerto "(...). Em face dos meus olhos abismados eu só tinha agora o 'faulteuil' vazio..."140 escrito em caracteres diferentes; quanto enfatizando o sentido de certas palavras, onde em "Agora sim: vivíamos"141 há destaque do termo "vivíamos", gerando a sensação de que a vida torna-se plena ao lado do "outro"; ou ainda demarcando a grafia das palavras estrangeiras, como "fauteuil", "sud-express" e "gare", como que glamourizando o barbarismo.

\footnotetext{
139 LEFEBVE, 1980: 140

140 SÁ-CARNEIRO, 1991: 69

${ }^{141}$ Idem, ibidem: 63
} 
O próprio termo "confissão" expressa a cisão entre a realidade externa e interna do sujeito, que provêm de uma só realidade geradora da pluralidade de hipóteses aventadas $^{142}$. Lida como a tragédia do sujeito, ser de desejo, que não consegue realizar ou permanecer na realização de seu próprio desejo (concretizá-lo plenamente).

Em relação ao gênero literário, a crítica da obra comumente classifica-a como novela; inclusive na dissertação de Maria da Graça Carpinteiro (1957) existe a atribuição de "novela lírica" ou "novela poética". Todavia, a própria obra também nos fornece classificações (contraditórias), existentes tanto na capa, onde se lê "narrativa", quanto na abertura, na qual o narrador diz: "Não estou escrevendo uma novela. Apenas desejo fazer uma exposição clara de fatos. "143.

Tendo como base a teoria ${ }^{144}$ de conto, novela e romance - questão não aprofundada aqui, por não ser o centro do estudo e exigir prolongado debate -, exclui-se a primeira, pois $A$ Confissão de Lúcio não "é, do ângulo dramático, unívoco, univalente $^{\text {"145, }}$, assumindo uma progressão de conflitos típica de formas mais extensas, posto que "da mesma forma que a novela, o romance apresenta 'pluralidade dramática', isto é, uma série de dramas, conflitos ou células dramáticas"146.

$\mathrm{Na}$ comparação entre novela e romance, compreende-se que os personagens são "personae" e a narração assemelha-se ao jogo teatral, mais propriamente devido às imagens descritas, do que propriamente pela narração em si. A presença simultânea de dramas, que se misturam e embaralham, gera a ação, a qual, por sua vez, é caracteristicamente interna por estar relacionada tanto ao "eu" em aproximação do seu outro "eu", quanto por negação e conseqüente morte em conflito com o

\footnotetext{
142 "São semelhantes as técnicas do romance e da confissão: o autor adentra o espírito de suas personagens para lhes seguir a corrente da consciência e sai de novo para descrevê-lo por fora." FRYE, 1973, 308.

${ }^{143}$ SÁ-CARNEIRO, 1991: 16.

${ }^{144}$ MOISÉS, 1985.

${ }^{145}$ Idem, ibidem: 1985, 20

${ }^{146}$ Idem, ibidem, 100
} 
convencional. Deste modo, "o drama das personagens há de ser [é] universal em si, por nascer de inquietudes espirituais perenes (a condição humana, o sentido da vida, o ser e não-ser, etc. $)^{p 147}$, e essa densidade de um núcleo dramático central aproxima a obra da categoria romance.

Outra característica que confirma a densidade do romance é seu caráter multifacetado na medida em que ele abarca várias formas de conhecimento, como a psicologia, a filosofia, a economia, a história, o que pode ser observado no comentário de Moisés:

“o romance é uma visão macroscópica do Universo, em que o escritor procura abarcar o máximo possível com sua intuição. Por isso, convergem para ele os resultados das outras formas de conhecimento. A História, a Psicologia, A Filosofia, A Política, A Economia, etc., colaboram permanentemente e de vários modos para essa recriação do mundo. $\mathrm{O}$ contrário ocorre, quer dizer, o romance pode servir ao historiador, psicólogo, filósofo, etc. para erguer algumas de suas especificas interpretações - mas em diferente dose. Por outro lado, a macroscopia posta na mundividência faz que exista subjacente no espírito do romancista, ou melhor, na obra produzida por ele, a mesma ambição de todo filósofo: englobar a variedade infinita do Universo num sistema unificador. Em suma: buscar um sistema de idéias, pensamentos e imagens que unifique num só corpo a extrema variação do Cosmos" (MOISÉS, 1985, 97-98).

A obra em questão não apresenta uma linha sucessiva ou possibilidade de continuação ilimitada após o climax, pois a partir de então o protagonista-narrador perde o

\footnotetext{
${ }^{147}$ Idem, ibidem, 98
} 
encanto pela vida, sem perspectiva de futuro e recluso em uma área rural de onde nunca sairia $^{148}$. Indica-se, portanto, na obra, limitação de vida e uma tendência à morte:

"Assim, no confronto entre a novela e o romance, verifica-se que a primeira ostenta uma estrutura fechada, ou apenas aberta horizontalmente, visto que o ficcionista, ao acumular em sucessividade as células dramáticas, deixa franqueada uma única saída para a realidade exterior: o epílogo da última 'aventura'. (...) Contrariamente, o romance exibe uma estrutura vertical, ou antes, em espiral, aberta em todas as direções para a realidade exterior, embora oclusa em seu. epílogo. (...) [ou seja] Pelo epílogo, tem-se a certeza de que tudo acabou; qualquer que seja o destino dos heróis (morrer ou sobreviver, casar e ser feliz ...), não se altera a impressão de o resto ser desimportante." (MOISÉS, 1985, 100-101).

Além dos elementos até aqui citados, outro em oposição à novela é o tempo, uma vez que nessa sua ordem é horizontal, linear, dentro de uma causalidade inflexível e, em contrapartida, na narrativa em questão, há predomínio do tempo espiral e a simultaneidade/intersecção cronológica. Percebe-se também avanços e recuos nos relatos da narração, confirmando o não linear ${ }^{149}$.

Oposto também à novela, além da quantidade de personagens da narrativa ser limitada e não numerosa, encontra-se Lúcio, o protagonista dividido, fragmentado,

\footnotetext{
148 SÁ-CARNEIRO, 1991: 135.

149 "Mas, que é o tempo? Para o exame do conto e da novela, não foi preciso colocar a questão, seja porque o tempo ali obedece quase sempre a um esquema único, o cronológico (...)." (Moisés: 1985, 105). No romance Moisés anuncia "três tipos fundamentais de tempo: tempo: 1) 0 cronológico, ou histórico; 2) o psicológico; 3) metafísico, ou mítico.

O primeiro é marcado pelo ritmo do relógio, consoante as mudanças regulares operadas no âmbito da natureza e empiricamente perceptíveis (...). o tempo psicológico se opõe frontalmente ao outro: (...) tempo interior,imerso no labirinto mental de cada um, apenas cronometrado pelas sensações, idéias, pensamentos, pelas 'vivências'. (...) o tempo metafísico, ou mítico é o tempo do ser. Acima ou fora do tempo histórico ou do tempo psicológico, embora possa neles inserir-se ou por meio deles revelar-se, é o tempo ontológico por excelência, anterior à História e à Consciência, identificado com o Cosmos ou a Natureza. (...)" (Idem, ibidem, 107-109).
} 
duplo, e não sendo substituído a cada drama exposto, mas confirmado em cada um deles, por todos serem suas partes e ele ser que nelas se espelha.

Na novela "o narrador, onisciente as mais das vezes, não esconde que conhece a história e que a conta ao leitor como se recordasse um passado indelevelmente presente em sua memória"150, mas na narrativa em questão Lúcio (o "eu"), o narrador, constrói sua própria realidade psicológica e pessoal - aparentemente aquém da pretendida dimensão metafísica ${ }^{151}$-, o que pode ser atribuído à característica de alguma outra forma literária em prosa.

Alencados os diversos contras pela classificação da obra como novela, apesar de terem-na rotulado como tal, sua estrutura assemelha-se mais a do romance, com a restrição, à semelhança deste, de não extrapolar o universo do "eu". Deste modo, um importante tópico a ser levantado é a do romance recriar a realidade, enquanto a poesia uma realidade, pendendo então a narrativa $A$ Confissão de Lúcio para uma poesiapoética (universo do "eu"), e, por conseqüência, para a prosa com narração interior ou psicológica.

Deste modo, consciente dos riscos na constatação de um processo de especularidade entre vida e obra na análise do texto literário, torna-se possível sugerir que $A$ Confissão de Lúcio evoca a ficcionalização da vida de Mário de Sá-Carneiro, vivida intensamente a partir de seu "eu", e posta em forma de literatura, confirmando sua vertente artística, mas também compreendida como um retrato da realidade do homem moderno.

Os fatos principais da história são narrados até o capítulo sete, e já a partir da abertura, com sua estrambótica constatação: "Aliás, por muito lúcido que queira ser, a

\footnotetext{
${ }^{150}$ Idem, ibidem, 64

${ }^{151}$ A novela "(...) não admite que a realidade seja polimórfica, 'transcendente', ‘oculta”' (Idem, ibidem, 61).
} 
minha confissão resultará - estou certo - a mais incoerente, a mais perturbadora, a menos lúcida"152. Aqui se percebe estar diante de algo incomum, não normal, já que o narrador fala e cita ter sido acusado de um crime e a argumentação ou o jogo de linguagem utilizado o que garante o estabelecer dessa verdade inverossímil. 0 mistério aqui instaurado seria representativo do presente na própria vida, como se comparados à ficcionalização das pequenas obscuridades vividas, mistérios do ser.

O protagonista Lúcio Vaz é um jovem português que vive em Paris no período em que a boemia estava vinculada à vida intelectual, realidade onde impera o luxo. Viera de Lisboa em torno de 1895 para estudar direito. Gervásio Vila, um escultor de Lisboa é quem o introduz nesta sociedade literária e artística, em torno da qual gravita a milionária Americana que oferece uma grande festa, para a qual é convidado. É apresentado a Ricardo de Loureiro, que já conhecia até então somente por suas obras, e tornam-se ambos grandes amigos. Pouco tempo depois não se fala mais de Gervásio, apenas noticiando-se mais para o fim da obra o seu suicídio. A intimidade entre Lúcio e Ricardo cresce cada vez mais, ficando ambos com vínculos fortes de amizade e confidências. Subitamente, depois de dez meses de extrema identificação de um com o outro, não obstante seu apego por Paris, Ricardo retorna a Portugal, em 1896, o que faz com que se passe da amizade até então ali partilhada no dia a dia ao isolamento de cada um em cidades diferentes por um período de um ano. Por estar com a saúde e as finanças abaladas, Lúcio retorna a Lisboa, mas eis que surge no reencontro de ambos a constatação do casamento de Ricardo de Loureiro.

O perfil de mulher bela e enigmática, preconizada por Ricardo quando em discursos e confissões a Lúcio em Paris, espelha-se na sua mulher Marta. A atração do protagonista-narrador por tal mulher é imediata, estabelecendo o triangulo amoroso. A partir deste relacionamento imoral, Lúcio sente-se culpado por estar traindo o amigo; o

\footnotetext{
${ }^{152}$ SÁ-CARNEIRO, 1991: 17
} 
que é agravado ainda mais ao saber que Marta é amante de outro amigo, o russo Sérgio Warginsky. Ciente de que Ricardo também sabia desse caso amoroso entre sua esposa e Warginsky, sem se abalar, fica indignado, pela falta de orgulho do amigo. O conflito entre os valores morais e o ciúme conduz Lúcio à angústia, e conseqüente retorno e tentativa de isolamento em Paris.

Santa-Cruz de Vilalva, grande empresário português, requisitada a Lúcio sua peça teatral "A Chama" para montagem em Lisboa, não fazendo exigência de atuação nos preparativos. Sem maiores explicações e repentinamente, Lúcio retorna a Lisboa com uma nova idéia para o último ato, mas reporta-se a Vilalva somente três dias após sua chegada. Sua nova idéia causa conflito com o empresário, levando à suspensão dos ensaios e conseqüente isolamento de Lúcio do círculo de amigos literatos lisboeta. $\mathrm{O}$ fim trágico da obra, enfim, é ser queimada, Lúcio a atira ao fogo.

Resolvida a questão de sua peça, Lúcio vaga pela cidade durante semanas, sem sequer cogitar retorno a Paris. Casualmente depara-se com Ricardo. Tendo-o ouvido por breve tempo, Lúcio revela seu grande desabafo, externando seu grande nojo. A reação de Ricardo é propor-lhe a explicação do grande mistério. Indo à casa de Ricardo, sobem ambos ao quarto de Marta, que em pé, diante de uma janela, nem tempo para se voltar teve. Ricardo desfecha-Ihe um tiro a queima roupa Marta cai sem vida, mas o corpo à janela é de Ricardo e aos pés de Lúcio aparece o revolver ainda em brasas. Marta desaparece como que por encanto. Lúcio entra em estado de pavor, e só retoma consciência quando se encontrava já preso. A sua vida desabara no instante em que Ricardo morrera, e a prisão aparece-lhe como um refúgio da irrealidade.

A não normalidade ante todo o enredo é o que aflora do drama por este nascer ou estar envolvido com a cisão interior dolorosa e interposta na figura de um duplo. Deste modo a ambigüidade apresentada pelo duplo está também refletida na 
pluralidade e simultaneidade dos dramas que surgem de Lúcio, o "eu", mesmo que mortovivo, por recordar e constituir-se fragmentado, plural. Como afirma Moisés, nos trechos supracitados sobre o romance e seu tempo metafísico, a obra aborda pensamentos e questões de um "eu", que reconstitui os dados de uma maneira não linear, por serem reconstituídos pela memória do narrador, assegurando a obscuridade desse "eu", o qual propriamente não se atreve a desvendar.

Como parte do romance psicológico, um elemento inovador da obra é a transferência de foco da ação: passa-se do exterior ao interior do sujeito e seus problemas. O sujeito passa a querer se descobrir, se compreender, e superar os entraves internos, o que é realizado pela oposição paradoxal entre o real e o ideal e através das sensações antes bloqueadas.

Logo de início, a própria epígrafe do livro (excerto de "Na floresta do Alheamento", de Fernando Pessoa ${ }^{153}$ ) remete a um drama subjetivo, a um problema interno do duplo. A ação da obra, por excelência externa, tenta encobrir os acontecimentos da ordem interna, foco e principal tópica desenvolvida, fazendo com que a estrutura da narração seja um amálgama de simultaneidade de conflitos, por serem reflexos e partes de um único "eu".

A partir do encontro de Lúcio Vaz com Ricardo de Loureiro, a trama se desenrola em torno destes, por serem desdobramentos de uma mesma pessoa, uma vez que Lúcio, o "eu" vai se transformando e identificando cada vez mais com o "outro" ao longo da narrativa. É possível afirmar tamanha similitude de identificação de ambos até

\footnotetext{
153 “... assim éramos nós obscuramente dois, nenhum de nós sabendo bem se o outro não era ele-próprio, se o incerto outro viveria”. (SÁ-CARNEIRO: 1991. 14; apud PESSSOA, 1965).
} 
nos tratamentos que dão à Paris (tratada como "o Paris") ${ }^{154}$, tornando-se difícil distinguilos, saber onde cada um se inicia ou acabe.

Deste modo, é possível compreender que a ação de $A$ Confissão de Lúcio é conduzida pelo duplo personagem Lúcio-Ricardo, o qual também devido a questão da fragmentação interna e tentativa de auto descobrimento pode ser entendido como personagem de caráter universalista. Essa fragmentação e divisão do ser é claramente posta em pauta na obra quando surge o personagem Marta, a qual se relacionará simultaneamente entre Lúcio-Ricardo, ratificando o mistério indisvendável. Esse triângulo amoroso baseia-se em dois únicos pontos: uma pessoa desdobrada no seu duplo, e Marta como a que possibilita, pela posse carnal, a consumação do afeto. Assim, está-se diante da real intriga motriz da narrativa, a que gira na ambigüidade de casos amorosos e entre amigos, por principalmente (ou supostamente) ferirem a postura moral frente a sociedade: há um caso de adultério. Na tentativa de abordar esquematicamente a intriga deste triangulo, pode-se entrever o seguinte quadro:

\begin{tabular}{|c|c|c|}
\hline & Contexto real & Contexto fantasioso \\
\hline $\begin{array}{l}\text { Ricardo } \\
\text { versus } \\
\text { Lúcio }\end{array}$ & $\begin{array}{l}\text { Amigos que pela } \\
\text { identificação de } \\
\text { "alma" tornaram-se } \\
\text { confidentes }\end{array}$ & $\begin{array}{l}\text { "eu" versus "outro"; duplo que partilha as mesmas } \\
\text { expectativas }\end{array}$ \\
\hline $\begin{array}{l}\text { Ricardo } \\
\text { versus } \\
\text { Marta }\end{array}$ & $\begin{array}{l}\text { Relação conjugal com } \\
\text { umar mulher } \\
\text { idealizadar por }\end{array}$ & $\begin{array}{l}\text { O "outro" cria uma condição de aproximação carnal ao } \\
\text { "eu": "não posso ser amigo de ninguém... (...) } A \\
\text { amizade máxima, para mim, traduzir-se-ia unicamente }\end{array}$ \\
\hline
\end{tabular}

\footnotetext{
${ }^{154}$ Isso pode ser observado na p. 47, na fala de Ricardo, e na p. 31, na de Lúcio, demonstrando a mesma paixão por Paris. Mesma situação ocorre quando Ricardo confidencia a Lúcio: "Eu não sei ter afectos. Os meus amores foram sempre ternuras... Nunca poderia amar uma mulher pela alma - isto é: por ela própria" (p. 63), e quanto a Lúcio: "Os meus afectos, mesmo, foram sempre ternuras..." (p. 134).
} 


\begin{tabular}{|l|l|l|l|}
\hline Ricardo - é bela e & pela maior ternura. (...) um desejo de beijar... de \\
enigmática. & estreitar... Enfim: de possuir! (...) Para as sentir, isto é, \\
para ser amigo de alguém (visto que em mim a ternura \\
equivale à amizade) forçoso me seria antes possuir \\
quem eu estimasse, ou mulher ou homem. Mas uma \\
Marta
\end{tabular}

Nota-se que ao longo da obra, e apesar do enigma e característica sobrenatural de Marta, que os três personagens que entrelaçam as intrigas dos casos esquematizados são caracterizados com vários detalhes. Apesar de Lúcio expressar minuciosamente (e também paradoxalmente ou de modo duvidoso) sua problemática interna, e ser esta a principal questão da obra, suas características físicas apresentam-se extremamente raras, pois à exceção da idade e profissão, o leitor não entreve nas linhas nenhuma outra característica.

O "eu" interior de Lúcio-Ricardo cria a utópica Marta, reforçando a fantasiosa maneira de pensar de Ricardo de Loureiro. Fica evidente que se trata, no ideal desse 
duplo Lúcio-Ricardo, de uma mulher perfeita e complementar à situação almejada: ela aumenta e confirma os planos do duplo.

Já dentre os personagens de menor expressão dentro da obra, mas que desempenharam, contribuíram à trama e entrelaçamento do triangulo amoroso, direta ou indiretamente, encontram-se Gervásio Vila-Nova, escultor português que vivia em Paris, e Sérgio Warginsky, cuja fisionomia irritava Lúcio por sua extrema beleza e, em contrapartida, encantava Ricardo. Desses dois personagens, respectivamente, há as seguintes descrições:

“(...) o seu corpo [de Gervásio] de linhas quebradas tinha estilizações inquietantes de feminilismo histérico e opiado, umas vezes - outras, contrariamente, de asceticismo amarelo. (...). Entretanto, coisa bizarra, no seu corpo havia mistério - corpo de esfinge (...). Uma criatura superior (...) uma destas criaturas que se enclavinham na memória - e nos perturbam, nos obcecam. Todo fogo! todo fogo!" 156

“(...) Os seus lábios vermelhos [de Sérgio], petulantes, amorosos (...) cabelos de um loiro arruivado (...) olhos de penumbra áurea (...). Enfim, se alguma mulher havia entre nós, parecia-me mais por ser ele do que Marta. $(\ldots)^{m, 157}$

A importância de Gervásio foi a apresentação do "eu" ao "outro", bem como iniciação ao mundo literato e artístico parisiense, círculo social no qual Lúcio entra e se integra. Já em relação a Sérgio Wargisnky, sua importância está no seu envolvimento com Marta, como segundo amante, e os laços de amizade com Ricardo - por quem também despertava desejos de ternura -, que tanto irritavam como despertava ciúme em Lúcio. Além dessas intrigas secundárias, acrescentam-se outras de relativa importância

\footnotetext{
${ }^{156}$ SÁ-CARNEIRO, 1991: 19-20

157 Idem, ibidem: 62-63
} 
em torno dos personagens, também deuteragonistas, como a Americana e o empresário Vilalva:

\begin{tabular}{|c|c|}
\hline $\begin{array}{l}\text { Lúcio } \\
\text { versus } \\
\text { Gervásio }\end{array}$ & $\begin{array}{l}\text { Gervásio apresenta-se como anfitrião de Lúcio em Paris; } \\
\text { apresenta-o ao seu duplo. }\end{array}$ \\
\hline $\begin{array}{l}\text { Lúcio } \\
\text { versus } \\
\text { Americana }\end{array}$ & $\begin{array}{l}\text { A Americana teoriza e representa em seu espetáculo as suas } \\
\text { idéias sobre a voluptuosidade-arte, vinculadas ao sensualismo e o } \\
\text { erotismo. È também neste contexto do espetáculo, o início da } \\
\text { relação do "eu" e do "outro". }\end{array}$ \\
\hline $\begin{array}{l}\text { Marta } \\
\text { versus } \\
\text { Sérgio }\end{array}$ & $\begin{array}{l}\text { Idêntica e simultânea relação a de Marta e Lúcio. É por ele quem } \\
\text { Lúcio externa intempestuosas crises de ciúmes. }\end{array}$ \\
\hline $\begin{array}{l}\text { Lúcio } \\
\text { versus } \\
\text { Sérgio }\end{array}$ & $\begin{array}{l}\text { Por ser o segundo amante de Marta, Lúcio lhe tem extrema } \\
\text { antipatia, e ciúmes. }\end{array}$ \\
\hline $\begin{array}{l}\text { Lúcio } \\
\text { versus } \\
\text { Vilalva }\end{array}$ & $\begin{array}{l}\text { A recusa da mudança no último capítulo da peça de Lúcio rompe o } \\
\text { relacionamento entre ambos, e é possível interpretar isso como a } \\
\text { recusa de Lúcio à não mercantilização da arte. }\end{array}$ \\
\hline
\end{tabular}

Por ser um romance psicológico e seu protagonista duplo fragmentado, todos os outros personagens representam extensões ou continuações da dramatização do "eu" pelo "outro", na tentativa de abranger os contextos que os envolvem. 


\subsection{Do duplo ao abjeto}

"Hoje, falho de ti, sou dois a sós.

Há almas pares, as que conheceram

Onde os seres são almas.

Como éramos só um falando! Nós éramos como um diálogo numa alma.

Não sei se dormes (...) calma, Sei que, falho de ti, estou um a sós."158

As questões de ambigüidade levantadas na obra $A$ Confissão de Lúcio de Mário de Sá-Carneiro, referentes às oposições físicas e espirituais, entronizadas pelos personagens e neles constituídas, podem ser interpretadas como advindas da problemática metafísica, como o que busca a essência das coisas ${ }^{159}$, e da problemática psicológica, no sentido de ciência que estuda o espírito humano ${ }^{160}$; pois Sá-Carneiro parte do contexto fantasioso, do obscuro e sobrenatural e direciona-se ao seu interior, na tentativa de uma auto análise psíquica. Como exemplo maior disso, tem-se como princípio originário da obra, da confissão, uma verdade inverossímil, um crime "sobrenatural" cometido por Lúcio, e, sua escritura, como processo posterior - após os dez anos de clausura -, uma tentativa racional de elucidação dos fatos, uma análise psicológica dos ocorridos.

As questões amorosas e de amizades patentes, a partir do triângulo amoroso estabelecido, tornam mais ilustrativas tanto as questões de casos psicológicos -

\footnotetext{
${ }^{158}$ FERNANDO PESSOA. "Sá-Carneiro". In: PESSOA - Obra Poética, Volume único, p. 563

159 LALANDE: 1999, 667, 2ª acepção

160 Idem, Ibidem, 888, 1ª acepção
} 
o "eu" e o "outro", o duplo e o tripartido ${ }^{161}$-, como nos casos metafísicos, exemplificados em torno de Marta, mulher enigmática, sem passado, que em morte "evapora-se", extensão e criação de Ricardo para realização carnal do desejo de possuir Lúcio.

Consciente dos riscos na constatação de um processo de especularidade entre vida e obra na análise do texto literário, pode-se ousar dizer, a essa altura, que em A Confissão de Lúcio Mário de Sá-Carneiro está sugerido como autor, em Lúcio Vaz, e refratado como personagem no duplo e em Marta. Lúcio e Ricardo, fragmentos de um, utilizam Marta, o feminino de Ricardo, como recurso para satisfação dos seus anseios. Mas almeja-se o impossível, desejos metafísicos de incorporar um ao outro, de possuir, dando valor extremo ao mistério, e ao mesmo tempo, gerando repulsa por ser estranho e inaceitável à sociedade, conduzindo à morte.

Essa cisão presente na obra e vista como motivo ou objeto da análise do narrador, acaba por transformar o malogro do não possuir o outro como almejava - pois o "outro" morre e o "eu" torna-se morto-vivo -, em literatura, confissão. Na origem da cisão, subentende-se, por uma lógica do recalque que se procurará demonstrar, o choque com a realidade exterior como causa da dissociação do seu ser.

Deste modo, torna-se patente uma estilização, pela construção fictícia, da estrutura tripartite da psique, tal qual Freud $^{162}$ descrevera em inícios do século $\mathrm{XX}$, relativa às instâncias mentais, o "id", o "ego" e o "superego". O "id" é a instância das pulsões de vida e de morte, trata-se da vida inconsciente e compreende o que se passa no nosso interior e se apresenta através dos sonhos ou de certos impulsos. Já o "ego" é a base da vida mental, que media os conflitos entre o indivíduo e o ambiente e entre as próprias instâncias psíquicas. Em contrapartida, o "superego" corresponde à censura moral, instância repressora a favor da cultura e boas normas e atuando principalmente

\footnotetext{
${ }^{161}$ Ver quadro relativos às intrigas às páginas 67, 69 e 70.

162 FREUD: 1998.
} 
sobre o "id", foco das pulsões e descompromissado com a vida social.

$\mathrm{Na}$ tentativa de estabelecer comparações com as constatações freudianas e os personagens do triângulo amoroso da obra, pode-se entrever, assim, Lúcio como projeção do "ego", por aceitar a realidade, após selecionar e controlar os impulsos provenientes do "id" - pode-se interpretá-lo como o consciente. Ricardo, por sua vez, poderia ser tomado, em parte, como projeção do "superego", instância psíquica mediadora que ultrapassa o "ego", sendo subconsciente - processos que influenciam a conduta. E finalmente Marta pode-se supor como projeção do "id", receptáculo dos impulsos instintivos, dominada pelo prazer e desejo - instância psíquica que surge nos momentos falhos, em que não há o controle da consciência ${ }^{163}$. Deste modo, como criação de Ricardo, Marta, representação dos impulsos e dos desejos, aparece quando a consciência, Lúcio, não se faz vigilante, e, em contrapartida, Ricardo deixa extravasar os fatos psíquicos latentes, o desejo de possuir, como exemplo disso é o próprio momento em que Marta surge: na ausência de Lúcio, em Portugal, como esposa de Ricardo.

É importante ressaltar um dos principais meios de enfrentar a pulsão que deve ser renunciada: o recalque; de acordo com Freud (1913) este é necessário quando alguma pulsão entra em conflito com uma idéia cultural ou ética, a qual encontra se bem estabelecida no ideal do superego, ou seja, o superego ao protelar um "desejo" indefinidamente, pode transformá-lo em um recalque.

O principal impasse da obra, a necessidade da criação de um recurso para a efetivação e concretização da posse de Lúcio por Ricardo, Marta, faz com que a trama gire em torno da expectativa de criação e manutenção desse personagem. Trata-se de uma alma sexualizada, e já sua criação ou elaboração por Ricardo significa uma vitória -

\footnotetext{
${ }^{163}$ Esta comparação não segue plenamente as teorias psicanalíticas, por identificar Ricardo como instância mediadora entre o "ego" e o "id" (Lúcio e Marta) sem identificá-lo plenamente com o impulso repressor do superego, o que seria reduzir o personagem-poeta, por ele não funcionar totalmente como árbitro, mas compreendendo-o como aquele que induz o surgimento da parte instintiva de Lúcio.
} 
“Triunfo inigualável! Grandioso segredo"164.

Como confirmação das constatações freudianas às personagens, tem-se o segundo amante de Marta, Sérgio Warginsky. Nessa relação amorosa entre Marta e Sérgio, é curioso perceber um homem feminilizado, que o "ego" repudia, o superego entende como proibitivo, mas sendo possível ao "id", que o possui. Deste modo, Marta pode ser compreendida como o impulso homoerótico. É a partir da festa apoteótica da Americana, momento em que a voluptuosidade e sensacionismo tornam-se mais densos, que a amizade tão identificatória de Lúcio e Ricardo começa.

Mário de Sá-Carneiro, por um processo de análise interna, expõe em sua obra a possibilidade de visualização do "outro" em Marta, que ao evaporar leva consigo também Ricardo, restando no plano real somente Lúcio, o morto-vivo, que se também se utiliza para analisar tal processo.

Desse modo, as incoerências do narrador em relação a Marta estão relacionadas a ela ser ambivalente, pois salvífica e infernal, ora vista como companheira ideal, ora como encarnação do mal, criadora e destruidora da vida. Marta como materialização da alma é o recurso da ligação do "eu" e do "outro", pois o ser tenta ultrapassar a si próprio, possuir aquele com quem se identifica. Este modo de auto superação encontra respaldo na quebra do real e do ideal, encontrando base também nas diferentes sexualidades, como onanismo, heterosexualismo e homosexualismo.

O onanismo permite a autocontemplação e é peculiar ao narcisismo; o momento da obra que ilustra tal sensação é quando Ricardo olha-se no espelho e não vê sua imagem refletida, pois havia ultrapassado a si mesmo ${ }^{165}$. Já a homossexualidade está

\footnotetext{
164 SÁ-CARNEIRO: 1991, 127

165 "Por acaso olhei para o espelho do guarda-vestidos e não me vi refletido nele! Era verdade! Via tudo em redor de mim, via tudo quanto me cercava projetado no espelho. Só não via a minha imagem... Ah! não calcula o meu espanto... a sensação misteriosa que me varou... Mas quer saber? Não foi uma sensação de pavor, foi uma sensação de orgulho." (idem, ibidem: 81)
} 
como um desejo e é realizado pela criação de Marta, solucionando o problema do triangulo amoroso; além disso tal sexualidade é também adotada pelo segundo amante, Sérgio Waerginsky, por Ricardo sentir-Ihe também ternura.

Apesar de heterossexulismo atrair, também repele, como visto nas náuseas sentidas por Lúcio ao relacionar-se com Marta. No imaginário de Lúcio está havendo uma superioridade de Marta, que o incomoda. A seqüência da orgia nesse relacionamento vai tendo seus momentos entre amor e ciúme, atingindo o ódio e o horror suscitado pelo corpo, mas ao mesmo tempo atração gerada pelo enigma, pelo mistério que Marta é a ele, pois ela é o impulso homoerótico, e como Lúcio está em busca de uma resolução para sua sexualidade, essa mulher o fascina também por isso.

A heterossexualidade é encoberta pela relação conjugal de Marta e Ricardo, pois ambos são desdobramentos de um, o que é confirmado pelo beijo tanto de Marta quanto de Ricardo serem masculinizados e iguais. Além disso, confirma-se nesse ponto a hipótese do onanismo, pois sendo Ricardo o duplo do "eu", remete-se ao desejo de satisfazer somente a si próprio, por entregar-se e integrar-se a si. Assim o egotismo de Lúcio, devido sua densa análise interna, torna-o perceptível e o estimula sua confissão pessoal.

Com essa grande análise realizada sobre suas instâncias psíquicas, o "outro" desejado pelo protagonista aparece como um fragmento interno de si. Tem-se, assim, a questão de seu desdobramento de sua personalidade até Marta, recurso e terceira possibilidade.

Ricardo é quem faz Lúcio consciente da existência do "outro" e quem também o lança ao triângulo já estabelecido. A partir de então, Lúcio, o consciente, passa não somente a ver o contexto real, mas o essencial, passando a dialogar com 0 subconsciente e, posteriormente, com o inconsciente, quando este aparece. O outro se 
transforma, pois, na instância a atraí-lo para o mundo do mistério, da análise psíquica, quebrando os conceitos do real. Retomando os conceitos freudianos, esse "outro" pode ser compreendido como a instância psíquica libertadora do "ego", querendo libertá-lo, e instigá-lo aos impulsos de desejo do inconsciente. É ele, pois, o que desperta Lúcio, o que desencadeia a problemática do desdobramento na narrativa.

Nessa passagem do "eu" ao "outro", aparece então a instância obscura desconhecida do "eu", Marta, confirmando sua fragmentaridade presente no homem moderno, bem como rompendo com o normal ou conhecido, pois o espiritual torna-se concreto e vice-versa.

Desde o primeiro contato entre Ricardo e Lúcio, aquele atrai este, chegando a intimidade. Tornando-se amante de Marta, Lúcio sente-se arredio, inversamente ao ocorrido com Ricardo, que a partir de então se sente mais entusiasmado e com um excelente estado de espírito. Marta, instância inconsciente, enreda Lúcio, fazendo-o despertar para o seu enigma: quem é Marta? Lúcio fascina-se por este enigma, que o sufoca e o domina, chegando inclusive a duvidar da realidade: "(...) a minha obsessão seria uma realidade, existiria realmente no meu espírito; ou seria apenas um sonho que eu tivera e não lograra esquecer, confundindo-o com a realidade?"166.

O progressivo estado de angústia e desconfiança que assolava Lúcio chega a gerar visões inconcebíveis no plano real, pois crê ter visto a figura de Marta dissipar-se do fauteuil ${ }^{167}$ durante um recital de piano à casa de Ricardo. $O$ transe passa, e Marta rematerializa-se após o recital, o que faz Lúcio atribuir o fato a uma alucinação. Persegue agora um novo enigma, subseqüente do primeiro: como ocorrera o casamento entre Ricardo e Marta? Este enigma provoca-Ihe ânsias, dores físicas.

\footnotetext{
166 Idem, ibidem: 68

${ }^{167}$ ver trecho já citado à página 33 - SÁ-CARNEIRO, 1991: 68-69
} 
O estranho acontecimento do desaparecimento da imagem de Ricardo no espelho coincide com o momento em que Marta fora à casa de Lúcio e ambos envolviamse sexualmente com Lúcio na casa deste. Avaliando o ocorrido mediante os conceitos freudianos, esse enigma pode ser explicado pela interrupção das interdições do subconsciente, fazendo com que o desejo reprimido, ou recalque ficcionalizado em Marta, seja liberado e atinja o consciente.

Mas ao relacionar-se com Marta, em seus encontros amorosos, Lúcio percebe que tanto as feições quanto o beijo de Marta evocavam os de Ricardo, instância maior a persegui-lo, a puxá-lo para o indefinível e obscuro.

Ao longo da obra, Lúcio percorre uma caminhada que o leva do lógico ao ilógico, do consciente ao inconsciente, pois a confissão aborda sua psique, seu desdobramento. Nessa deambulação, o momento em que o "outro" surge, na apoteótica festa da Americana, é despertado, por esse "outro", o desejo de posse do "eu". Entretanto, numa última tentativa de retomar sua lucidez, Lúcio retorna a Paris alegando inclusive que vencera, mas essa tentativa é em vão, pois seus pensamentos estão voltados a Lisboa, onde permaneceram Ricardo e Marta.

No retorno de Lúcio a Lisboa, há o reencontro entre Lúcio e Ricardo, momento em que intempestivamente ambos vão ao encontro de Marta para tentar elucidar o mistério. Ricardo dispara um tiro à queima roupa em Marta. Lúcio assiste essa cena do crime, um verdadeiro quadro de inverossimilhança, pois a arma do crime está aos seus pés e o corpo de Ricardo no exato local onde tombara Marta desfalecida. Marta desaparecera e a Lúcio seguem-se os anos de prisão, apesar de não ter praticado o crime, e nem se defendido da acusação, o que pode ser compreendido com um autoaniquilamento.

Do outro lado da linha tênue que separa a obra da vida em Mário de Sá- 
Carneiro, as cartas do autor testemunham as suas angústias e sonhos, em que seu ser está caracterizado pela secção entre o artista brilhante e o homem banal, pólos aos quais se pode ainda acrescentar a sexualidade não resolvida ou homossexualidade não vivida.

Deste modo, a realidade de dentro e a realidade de fora são os dois modos que permitem avaliar os elementos da narrativa. Da divisão destes dois planos, entre o ideal e o real, surge o "eu ideal", o "outro"; porém a coexistência de ambos produz mais divisões, pois ambos se fundem, mas se excluem. Lúcio e Ricardo-Marta conseguem se unir, mesmo que o consciente esteja questionando e em guarda, mas essa manutenção não é mantida, e se aniquilam: o inconsciente ao "matar" o subconsciente, morre, e ao consciente resta ser morto-vivo, pois foi apartado do desejo, sem perspectivas.

A morte em vida de Lúcio pode ser entendida como um sono mais profundo do que o que está tendo, o seu estado morto-vivo. O "eu" real vê-se simultaneamente como diferente e semelhante ao seu "eu" ideal, vetor para a sexualidade onanística, por satisfazer e voltar-se a si mesmo. A busca da identidade e a análise da psique é que provocam o desmembramento, cuja manutenção é impossível e não leva a nenhuma solução, como, por exemplo, à semelhança de Ícaro, em que o "eu" idealizado se extingue, arrastando o "eu" real a um desencontro. Deste modo, a impossibilidade se não ser "eu", nem o "outro", põe Lúcio como um ser intermediário às realidades que criou, encontrando-se alienado.

Voltando à temática amorosa, na peça de Sá-Carneiro intitulada "Amizade", ela é expressa através do personagem Cesário, já no final do drama, e reduz-se, conforme apontou François Castex ${ }^{168}$, a quatro pontos principais: o amor nasce a partir da amizade; a união cada dia mais íntima das almas implica fatalmente a união dos corpos; nada pode contrariar a força do amor, e é necessário abandonar-se a ela para conhecer a 
felicidade; isto implica um total desprezo pela opinião da maioria das pessoas que, de fato, nunca serão chamadas a conhecer um amor de tal natureza.

Curiosamente, é possível identificar esses mesmos pontos em A Confissão de Lúcio, se lembrarmos que: da amizade entre Lúcio e Ricardo nasce o amor; dessa união espiritual surge a necessidade de Ricardo, depois assimilada por Lúcio, da posse carnal; a homossexualidade não pode contrariar a força do amor - Ricardo devido a essa dificuldade, cria Marta, seu prolongamento feminino, para poder possuir Lúcio; o triângulo imaginário engendra uma narrativa cuja matéria e desfecho não se podem prever pelo código penal, tampouco se deixa explicar pelo princípio de realidade vigente ou pela mera verossimilhança.

Mas mesmo inscritas na pára-realidade da ficção, as personagens nunca atingirão a felicidade. Entre os êxtases de carnes brancas, Lúcio sente náuseas e não abdica da sua obsessão. Por outro lado, se desvendar o segredo, nada mais o atrairá em Marta.

Deste modo, a grande questão daí advinda é que a união perfeita dos corpos e das almas é impossível:

“União traduzida no triangulo inexistente do autor - o 'eu' - Ricardo Loureiro, - o 'outro' - e Marta - alma do outro mas criada para o amor que afinal una o eu e o outro - reduz-se à suspensão final do irresolúvel. 0 'outro', a projeção anímica do 'outro', foram sacrificados para continuar a preservação do 'eu'. Mas condicionado apenas a sí próprio, o ‘eu’ define-se como incompleto e o círculo, que se fechou, recomeça: ou refaz a aventura e percorre de novo o reconhecimento de um elo entre o 'eu', percebido real, e o 'outro', adivinhado ideal, aceitando o perigo de confundir os limites proibitivos de ambos; ou abdica, reconhecendo-se embora como um morto 
que persiste" 169

Entretanto, é possível discordar de Galhoz ao considerar o triângulo inexistente, porque se considera o nível metafísico da realidade - como descartá-lo do real? Quanto ao sacrifício do outro, é pertinente em relação à alma do outro, alvo do revólver de Ricardo, que quer continuar com Lúcio, não sabendo que, se destruir a sua alma, destruir-se-á também, constituindo um suicídio indireto, conduzindo o "eu" à morteem-vida, para o qual, contrariando novamente Galhoz, não há possibilidade de refazer a aventura, uma vez que Lúcio diz textualmente:

"Morto, sem olhar um instante ao redor de mim, logo me afastei para esta vivenda rural, isolada e perdida, donde nunca mais arredarei pé.

Acho-me tranqüilo - sem desejos, sem esperanças. Não me preocupa o futuro. O meu passado, ao revê-lo, surge-me como o passado de um outro. Permaneci, mas já não me sou. E até a morte real, só me resta contemplar as horas a esgueirar-se em minha face... A morte real - apenas um sono mais denso..."

O crime de Ricardo, que acaba consumando o seu suicídio, é ainda a morte metafórica de Lúcio: este passa a viver na prisão, que é negação da vida, ou uma vida vegetativa, exilado dentro de si próprio, em uma condição de pré-morte. Aqui vale destacar um trecho de Walter Benjamim, no qual ele abordou o tema do suicídio na modernidade:

"As resistências que a modernidade opõe ao impulso produtivo natural do homem são desproporcionais às forças humanas. Compreende-se que ele vá enfraquecendo e busque refúgio na morte. A modernidade deve manterse sob o signo do suicídio, selo de uma vontade heróica, que nada concede 
a um modo de pensar hostil. Esse suicídio não é renúncia, mas sim paixão heróica. É a conquista da modernidade no âmbito das paixões"171.

Assim, pode-se compreender que o suicídio, como a "paixão particular à vida moderna", aparece na representação ficcional de Mário de Sá-Carneiro, em um ato radical de niilismo purificador.

Da impossibilidade de amor à solidão suicida, Lúcio percorre o mais doloroso caminho, o do autoconhecimento; na mesma impossibilidade do crime/morte deliberada, Ricardo percorre a grave crise que reintegra "aquele que é seccionado pelo sexo": Ricardo/Marta, e que se aparta de Lúcio de vez. Lúcio ensimesma-se no seu egoísmo, incapaz de ver os outros, de aceitar o seu próprio duplo, e perde a aposta que fizera, na sua grandeza, ao reduzir-se a um "morto-vivo". O complexo de Eros restou irrealizado e irrealizável, porque Thanatos venceu com a pulsão do personagem para a morte deliberada: amor expulso pela morte que viabiliza a ruptura do "ego" e do "superego", mas que, paradoxalmente, reúne o "sexionado": ao matar a "fugitiva e evanescente" Marta, Ricardo suicida(-se) e leva Lúcio para a morte, reintegrando o ser disperso para o mistério maior, mistério que alimenta todas as dúvidas, e que ninguém pode resolver.

No nível estrutural, as personagens da obra podem ser agrupadas como masculinas e femininas; contudo, à revelia dessa divisão, aspectos desconhecidos da personalidade do protagonista e dos deuteragonistas são mostrados. Lúcio, Gervásio, Ricardo, Sérgio Warginsky, de um lado. A Americana exótica e Marta, do outro.

Na festa magnífica e estranha em casa da Americana, fica clara a oposição entre o sensualismo, o erotismo, a liberdade total das roupas das mulheres, quase nuas, enfeitadas a ouro, a cintilações esbraseadas de um lado, e a seriedade ascética dos 
trajes masculinos de outro, dentre os quais destaca-se Gervásio, impecável, mas original, o perfeito dândi. Na discussão entre a Americana e Gervásio ${ }^{172}$, a voluptuosidade para ela é arte, ao que ele responde "Não; a voluptuosidade não era uma arte. Falassem-Ihe do ascetismo, da renúncia. Isso sim!... A voluptuosidade ser uma arte? Banalidade..."173.

As mulheres são excessivamente belas - perfeitas, apresentadas pelo ângulo do maravilhoso, mas também da androgenia ${ }^{174}$ : primeiramente aparece a Americana (prefiguração da androgenia) que possui o fogo, e posteriormente Marta age masculinamente, possuindo e dominando Lúcio. Marta é um ser híbrido, andrógino ${ }^{175}$, assim como Sérgio Warginsky, alto, elançado, fulvo, belo rapaz de 25 anos, que exprimia a sensualidade naquele grupo de artistas, corpo que evocava o de Gervásio Vila-Nova, lábios vermelhos e petulantes, olhos de penumbra áurea, voz sonora, vibrante, esbraseada, de beleza excessiva, enfim, "se alguma mulher havia entre nós parecia-me mais ser ele do que Marta"176.

O desejo homoerótico é, enfim, a força motriz que direciona o olhar e a voz do narrador, selecionando a tipos masculinos belos, descritos minuciosamente, bem como narrando e descrevendo a atitude passiva do homem em face da mulher (caso LúcioMarta). Gervásio é também uma figura belíssima, artista sedutor que catalisa todas as atenções do grupo que freqüenta, acentuando (por contraste) a timidez e o comedimento de Lúcio. No processo de construção imaginativa do desejo, Gervásio será substituído, no decorrer da narrativa, por Ricardo de Loureiro, o outro "eu", como alternativa de melhor

\footnotetext{
172 ver trecho à página 53 - Sá-Carneiro, 1991: 24

${ }^{173}$ Sá-Carneiro, 1991: 24-25

174 Semelhante referência aparece no mito literário de Salomé: “(...) mulher fatal adorada e execrada, fascinante e terrível, uma deusa de grande beleza e luxúria. (...) O episódio bíblico revisitado pelos anos 1890 torna-se o mito do eterno combate entre a mulher e o homem, a carne e o espírito, o irracional e o intelecto, a beleza e o pensamento; o amor e a morte fazem aí um intercâmbio de seus atributos. (...) a figura de Salomé desenvolve-se sobretudo por associações de idéias, na ambivalência e ambigüidade do onirismo; ela é virgem e cortesã de prostíbulo, deusa adorada e meretriz vilipendiada, moçinha histérica e alegoria de Mulher absoluta. (...) ela pode, em última instância, tornar-se uma representação da Obra de arte pela qual só nos resta morrer" (BRUNAL: 2000, 807-811).

175 Portanto, o interseccionismo com características decadentistas constrói um corpo andrógino.

176 Sá-Carneiro, 1991: 63
} 
aceitação no universo de valores de Lúcio - um objeto de desejo sublimado. Tanto Gervásio quanto a Americana propiciam o encontro do "eu" com esse outro "eu", de Lúcio com Ricardo e, por extensão, com Marta. Encontro não casual, mas determinado pelo destino. Por oposição a Gervásio, que expressa o gosto decadente, trajando sempre o preto, elegante, mas tétrico, Lúcio e Ricardo compreendiam-se na delicadeza. Ainda que aparentemente diferentes, eram iguais no amor por Paris, cidade também tratada de modo híbrido, pelo estranho gênero masculino atribuído ao nome - "O meu Paris""177 -, e onde tudo Ihes é litúrgico. Em relação a essa mesma Paris que ora aparece masculinizada, ora se sublima, também é expresso um desejo sensual e voluptuoso, porque a saudade do protagonista "foi então a mesma que se tem pelo corpo de uma amante perdida...", querendo entrelaçá-la consigo para melhor a exaltar numa ternura louca.

Nessa cadeia de projeções sobre o espaço, a grande questão é a impossibilidade de possuir uma criatura do mesmo sexo, o que leva Ricardo à criação de Marta. Ricardo transfigura-se "aureolado pelo brilho intenso, melodioso, dos seus olhos portugueses ${ }^{\prime 178}$ torna-se belo em alguns instantes. Lúcio não sabe ainda como narrador (no tempo da enunciação) se o seu amigo era ou não era formoso. Ricardo considerava o feminino, a mulher, a apoteose máxima, contrapondo o corpo feminino ao masculino: "carne esplêndida... loura de álcool" e "carne - tristonha, seca, amarela; sem brilho e sem luz...", lembrando-lhe "um desejo perdido de ser mulher"179. O masculino e o feminino, oposição presente em tudo na vida, desde entre o céu e a terra, a água e o fogo, o sol e a lua, acionam a problemática humana que, nas personagens, não se reduz à simples polaridade de uma divisão que conjugue, de forma coerente, as potencialidades de sexo e gênero, tampouco que discipline o desejo, que culmina na dissolução do "eu" diante da

\footnotetext{
177 Idem, ibidem: 23

178 Idem, ibidem: 53

${ }^{179}$ Idem, ibidem: 56
} 
necessidade de posse, uma posse sexualizada.

Sob o signo de uma sexualidade híbrida, as personagens tentam fugir dessa polarização, buscando uma alternativa para a união de seres do mesmo sexo.

"O mundo masculino sela-se de versatilidade e de transferência. Prisioneiro iniludível do fatalismo da tentação, luta pela afirmação da superioridade do espírito, sua condição não equívoca e projeta-se no indefinível da saudade da alma como mito fundamental da sua integridade não dispersa... Como defesa surge então, na personalidade masculina, uma fugidia ou brutal transferência para um entretenimento sentimental da convenção feminina, salvaguarda e desvio não de uma impotência, mas de uma inibição e, até, de uma repugnância" ${ }^{180}$.

Ricardo, que desprezava o próprio corpo, que o enxergava como obstáculo, aspira, assim, a consubstanciar a perfeição das carnes brancas de mulher "a escoaremse frias, sob um lençol de linho..." ${ }^{\text {"181 }}$. Assim ele pode desdobrar-se, materializando a sua alma feminina - para enredar o seu próprio "ego" masculino que, ao possuí-la, possuía nela o corpo de todos os homens "que resvalavam pelo seu" ${ }^{182}$ e que, ao "sabê-la possuída por outro amante - se me fazia sofrer na alma, só me excitava, só me contorcia nos desejos..."183. Marta era possuída ou dava-se a três homens: Ricardo, Lúcio e Sérgio, o que despertava em Lúcio "um desejo perverso de que assim fosse..."184.

A experiência do múltiplo se concretiza para Ricardo e Lúcio, há o desdobramento da sua personalidade em masculino e feminino, fundindo-os; porém isso não é mantido, já que o "eu" se encontra ardido em ciúmes e em problemas morais, afastando-se do seu outro "eu" que idealizara toda a metamorfose para a fusão com o

\footnotetext{
180 GALHOZ: 1963, 105

181 SÁ-CARNEIRO, 1991: 54

182 Idem, ibidem: 102

${ }^{183}$ Idem, ibidem: 101

${ }^{184}$ Idem, ibidem: 102
} 
primeiro - objeto da sua própria adoração -, ocorrendo a reintegração de ambos somente com a morte-em-vida. Revela-se, assim, uma homossexualidade travestida em onanismo gritante e alienador, que leva o homem à inadaptaçâo e à fuga - até mesmo de si.

A impotência de ser arrasta o protagonista duplo à solidão e à morte. Tanto no plano objetivo quanto no plano ideal, ele é incapaz de estabelecer relações de amor e de amizade verdadeiras, tornando-se amigo de ninguém, desiludindo-se até não poder nem mesmo ser. A significação do ser patenteada em grandeza, em mundos dourados, em genialidade e arte, em exceções, rui diante da realidade crua, frustrando o protagonista que, dessa forma, não consegue ser - para ser, faltou-lhe algo inatingível que o fez falhar. E nessa falha entre os outros e em si, vê-se o ser que não conseguiu ser além e que, ao mesmo tempo, não pode mais permanecer aquém. Como transpor essas barreiras cruciais? Como arrojar-se a penetrar nos mundos que idealizou e ser o seu rei? De que maneira regressar a si e ser o que era antes do delírio, abraçando a esperança? É-lhe impossível - já não pode regressar, já não é - é o não-ser, liberto de um passado que parece não ser seu, permanecendo, mas já não sendo. Quase foi o que criou, quase triunfou; no entanto, a sua fragmentação foi mais forte, assegurando dicotomias inconciliáveis.

Lúcio foi incapaz de entender Ricardo na sua ânsia doida de possuir, todo fogo, mantendo-se com medo de si mesmo, ainda que quisesse ser e tivesse quase conseguido ser o outro, mas se desespera devido à sua atitude e se encaminha para a morte. De certa forma foi Lúcio quem matou Ricardo e, por outro lado, também se excluiu da vida em uma crise irrecuperável com a sua imagem apagada do espelho outra vez. E presa de uma vida insuportável em que não tem nada senão dor - a dor de não sentir o próprio íntimo como seu e a dor de não poder sair de si para aceitar a realidade do outro, a dor de ser quase: "A carência de uma dimensão, a dimensão metafísica, constitui assim o nó da tragédia deste poeta superiormente dotado, porque a tragédia do 'Quase' é, 
afinal, a sua tragédia"185.

Tragédia da limitação de quem alçou vôo para o infinito, que remete para o drama central:
"Eu não sou eu nem sou o outro
Sou qualquer coisa de intermédio:
Pilar da ponte de tédio
Que vai de mim para o outro."186.

Pode-se aqui, nas palavras de Pessoa, entrever o drama de $A$ Confissão de Lúcio como em que "uns morrem; aos outros, tirando o instinto com que vivam, pesa a vida como morte, vivem morte, morrem a vida com ela mesma. E é na juventude, quando neles desabrocha a flor fatal e única, que começam a sua morte vivida" ${ }^{187}$.

Na sua confissão, revela-se o sentimento de quem percebe a significação do ser e do não-ser, sendo intervalo, intermédio entre o "eu" e o "outro", malogro inflexível que perdura na obra e na vida de Mário de Sá-Carneiro - expressiva confissão da sua realidade inverossímil.

O poder de escolha e de decisão do homem é veiculado por Ricardo de Loureiro, que diz que "as coisas em que me não vejo, nunca me sucederam"188, pois é ele quem conduz Lúcio à Marta e à perda de lucidez. Por outro lado, é um homem isolado que todos consideram, e que, entretanto, não é admitido em lugar algum. Esses são elementos opostos que constroem a essência - a vida vivida pelo avesso, atingindo o cerne do não visto ou quisto. A aparência, assim, pode ser enganosa, como quando os retratos mostram um ser "belíssimo, numa auréola de gênio"189, e simplesmente não seja

\footnotetext{
185 SAMPAYO: 1960, 213

186 SÁ-CARNEIRO: 1978,74

${ }^{187}$ PESSOA: 1946, 118

188 SÁ-CARNEIRO, 1991: 41

${ }^{189}$ Idem, ibidem: 54
} 
essa a expressão do seu rosto. Aplicando esta perspectiva aos personagens, pode-se aqui perceber que Lúcio corresponderia à aparência - o ser mais superficial e desperto -, e Ricardo-Marta como essência - âmago que se quer atingir na travessia de contrários -; essa fusão é tentada e alcançada temporariamente, mas Lúcio recusa a sua essência, a sua "devastação".

No processo de desmembramento da aparência e da essência, o protagonista perde-se no labirinto que ele mesmo criou e se dispersa, tentando ser tudo o que o provoca e incendeia - projeta-se na cidade, no seu dinamismo louco e frenético, quer "possuir vozes, gestos, sorrisos, aromas e cores!..."190, porque o seu "mundo interior ampliou-se - volveu-se infinito, e hora a hora se excede! É horrível. Ah! Lúcio, Lúcio! Tenho medo - medo de soçobrar, de me extinguir no meu mundo interior, de desaparecer da vida perdido nele..."191. O labirinto tornado infinito do meu "eu" arrasta o ser à dispersão que funde a aparência e a essência de todas as coisas que o autor transfigura. Da dispersão maior traduzida pelo triângulo Lúcio-Ricardo-Marta chegam até o leitor os ecos de um mistério irredutível com interrogações inquietantes, anunciando uma dispersão do ser tripartido em outros objetos, e tudo "se esgueira", "soçobra", "oscila", "resvala", "dissolve-se em rodopios", em "turbilhões", em "resvalamentos", em vertigem final, e se quebra ao ultrapassar a fronteira da aparência e da essência, da realidade de fora e da realidade de dentro, que estoura e se arremessa para o lado de cá, para o lado do leitor que já passou para o universo da ficção criada pela narrativa, entrelaçando o tempo, o amor, a morte, a arte e a vida como premissas maiores de um silogismo intrincado. Dispersão que pode tornar a alma visível e o corpo invisível, a adensar o drama que corporiza a transcendência do ser e a inatingibilidade antevista na arte.

Ligada ainda ao Sensacionismo, tal qual Mário de Sá-Carneiro concebeu,

\footnotetext{
190 Idem, ibidem: 52

191 SÁ-CARNEIRO, 1991: 52
} 
muito particularmente, a dispersão faz os dados colhidos pelos sentidos, pelas sensações, desarticularem-se e desagregarem-se, constituindo um verdadeiro delírio poético em que até as coisas mais banais são interiorizadas. Em busca de si mesmo, o protagonista se perde no seu labirinto e se define pela desarticulação da sua identidade na mais extrema dispersão do seu "eu" mergulhado no fogo e na água, elementos essenciais do mito de Ícaro, asas queimadas pelo desejo abrasador, morte recebida na placidez da água que apaga o fogo; mas nada mais pode fazer senão sustentar a leveza do ser que bóia, morto-vivo para a vida, impotente psicológica e metafisicamente. 


\subsubsection{Homoerotismo como abjeto}

O abjeto é um conceito desenvolvido por Julia Kristeva na obra Powers of Horror, de 1980, onde se estabelece um diálogo com teorias de Freud e Winnicott. Nesse estudo, pode-se compreender o abjeto como algo que desestrutura as regras ou conceitos - sejam eles éticos, morais, religiosos etc. -, fugindo à concepção do aceitável, desordenando o estabelecido, como se vê no trecho: "[é] o que perturba identidade, sistema, ordem. O que não respeita fronteiras, posições, regras. O meio-termo, o ambíguo, o composto. (...) $)^{192}$.

Outra possível leitura do termo, que expande e explica essa primeira, é sua ambivalência, pois simultaneamente repele e atrai: a abjeção "é imoral, sinistra, calculista e obscura: um terror que desagrega, um ódio que sorri, ${ }^{, 193} \mathrm{~A}$ contradição está vinculada ao preceito do corpo abjeto, representação daquilo que é rejeitado e reprimido na tentativa de manutenção da ordem:

"Respira, dentro da abjeção, uma daquelas violentas e sombrias revoltas de ser, direcionada contra uma ameaça que parece emanar de um exorbitante exterior, ou interior, atirada para além do escopo do possível, do tolerável, do imaginável. Ali ela reside, bem perto, mas ela não pode ser assimilada. Ela suplica, preocupa, fascina o desejo, o qual, entretanto, não se deixa seduzir. Apreensivo, o desejo revolve; adoecido, ele rejeita. Uma certeza o protege do vergonhoso - uma certeza da qual ele se orgulha prende-se a ele. Mas, simultaneamente, e da mesma forma, aquele ímpeto, aquele espasmo, aquele salto é sugado para um outro lugar tão tentador quanto condenado, que já está. Persistentemente, como um bumerangue inescapável, um vórtice de atrações e repulsões, ele coloca o que persegue

\footnotetext{
${ }^{192}$ KRISTEVA: $1985 ; 4$.

${ }^{193}$ Idem, ibidem.
} 
literalmente a seu lado."194

$\mathrm{Na}$ medida em que sociedade e cultura reprimem o id, não consentindo a livre expressão de desejos e pulsões, é possível, deste modo, vincular o termo de Kristeva ao recalque, termo freudiano em que, por sua vez, se estabelece que a pulsão seja protelada pelo superego, instância psíquica de ordem moral relativa ao subconsciente. Assim, a abjeção está sempre em discordância com o superego, manifestado este como conjunto de proibições e deveres, a favor da produção do "eu ideal". Dessa produção, o abjeto é o que sobra, discorda, destoa e desconcerta. Para exemplificar a filiação aos termos freudianos, eis uma passagem na qual a autora em questão os utiliza:

"O abjeto tem apenas uma qualidade do objeto - aquela de ser oposta ao eu. Se o objeto, contudo, através da sua oposição, me posiciona dentro da frágil textura de um desejo por significado, o que, de fato, me torna incessante e infinitamente homóloga a ele, o que é abjeto, ao contrário, o objeto descartado, é radicalmente excluído e me atrai ao lugar onde o significado colapsa. Um certo "ego" que, mesclado ao seu amo, um superego, pungentemente o mandou para longe. Aquele reside fora, além da estrutura, e não parece concordar com as normas deste."195

Perceba-se que a teorização de Kristeva se faz como descrição de uma experiência em primeira pessoa, salientando a ambivalência do sujeito-objeto nessa zona fronteiriça em que o abjeto se aloja.

"Uma assombrosa e repentina aparição do sobrenatural, familiar que fosse a uma vida opaca e esquecida, me aflige agora como sendo radicalmente separada, indesejável. (...) Um 'algo' que eu não reconheço como uma

\footnotetext{
194 Idem, ibidem, p. 1.

195 Idem, ibidem, p. 2.
} 
coisa. Um peso de insignificância, sobre o qual não há nada de insignificante, e que me esmaga."196

Deste modo, a idéia de abjeção vem da intenção de Kristeva propor essa nova análise da região do inconsciente, onde o self não seria nem sujeito nem objeto, mas sim abjeto, o qual, nessa perspectiva, é o que se encontra na fronteira, sem respeitar fronteiras $^{197}$. O abjeto não é uma qualidade em si, mas um relacionamento com uma fronteira e representa o que foi "atirado para fora daquela fronteira, seu outro lado, uma margem" ${ }^{198}$, uma ameaça à identidade.

Sobre a análise da sensação psíquica de perturbadora estranheza familiar, é importante também lembrar o artigo de Freud intitulado O estranho (Das Unheimliche), no qual há, inclusive, uma abordagem etimológica do termo:

“A palavra alemã 'unheimlich' é obviamente o oposto de 'heimlich' ['doméstica'], 'heimisch' ['nativo'] — o oposto do que é familiar; e somos tentados a concluir que aquilo que é 'estranho' é assustador precisamente porque 'não' é conhecido e familiar. Naturalmente, contudo, nem tudo o que é novo e não familiar é assustador; a relação não pode ser invertida. Só podemos dizer que aquilo que é novo pode tornar-se facilmente assustador e estranho; algumas novidades são assustadoras, mas de modo algum todas elas. Algo tem de ser acrescentado ao que é novo e não familiar, para torná-lo estranho." 199

Delineia-se, assim, uma experiência particularizada pela variação ou aparecimento simultâneo do familiar e do estranho. O prefixo un (traduzido como não) pode ser compreendido como expressão e efeito do recalque, de forma que a sensação

\footnotetext{
${ }^{196}$ Idem, ibidem.

197 Idem, ibidem, p. 69.

198 Idem, ibidem, p.69.

${ }^{199}$ FREUD, s.d.
} 
Unheimliche adéqua-se ao regresso do desejo inconsciente, manifestando-se ao sujeito como algo ao mesmo tempo estranho e familiar. Nessa tentativa Unheimliche, a realidade aparenta possibilitar o cumprimento imediato do desejo, por meio do sobrenatural.

Retomando a trama de $A$ Confissão de Lúcio, e tentando estabelecer comparações ao conceito de Kristeva e Freud, pode-se estabelecer Marta como um ser abjeto, pois ela desafia e quebra uma regra, o limite do que se acredita ser real ou não, pondo em dúvida sua existência, sendo, simultaneamente, criada por Ricardo. Assim, Marta é abjeta por suas características físicas e metafísicas, pois não se sabe ao certo da sua real existência - "existiria realmente (...) ?,200.

No momento em que Narciso de Amaral toca sua peça ao piano, na casa de Ricardo, e Marta dissipa-se ${ }^{201}$, confirma-se que essa mulher não se insere nos padrões positivos de um ser humano "normal", pois sua existência é ora metafísica, ora enigmática. Apesar desse elemento de repulsão, pois estranho e desestabilizador de ordem, o paradoxo deste personagem abjeto está na simultaneidade das características que atraem, as desejadas por qualquer um que dê valor à sensualidade, pois Marta era bela, co-existindo, assim, repulsa e atração.

Porém Marta não é abjeta somente pelos motivos supracitados, pois nela há também outro desregramento, o moral, ao cometer adultério e ser, conseqüentemente, criticada socialmente por Lúcio. Marta ousou fazer o que é desprezado pelas leis da sociedade, tornando-se, novamente, abjeta: “- Sim! Marta foi tua amante, e não foi só tua amante... Mas eu não soube nunca quem eram os seus amantes. Ela é que mo dizia sempre... Eu é que Ihos mostrava sempre! "Sim! Marta foi tua amante (...),202.

Marta, pela abjeção apontada, demonstra ser diferente, estranha, e suscita

\footnotetext{
200 SÁ-CARNEIRO, 1991: 68.

201 (veja à página 33 - SÁ-CARNEIRO, 1991: 68-69)

202 Idem, ibidem, p. 126.
} 
dúvidas relacionadas à identidade (humana) quanto à existência (corpo) e metafísica (alma), desafiando, ao mesmo tempo, tanto os preceitos tidos como verdades universais, como conceitos espirituais; mas não há somente um questionamento, pois o estranho, Marta, é aquele que não deixa definições claras, mas sim em brumas.

Ao diferente, em nossa sociedade, não se dá tanta importância, mas existe a curiosidade para ser analisado e geralmente taxado, fazendo com que seja, de certo modo, excluído. Nesse sentido, o abjeto pode ser compreendido como representativo ou o que abrange as identidades e ideais também "diferentes" ou que fogem à norma predominante social, como homossexuais, negros, bem como classes minoritárias que sofrem alguma espécie de preconceito público, por subverterem, revolucionarem ou desregularem uma norma; e geralmente associados, no campo literário, aos personagens também abjetos, como almas a corromperem a existência "real" - como Marta -, monstros e bruxas o belo, etc.

Vale também observar e confirmando o postulado de Kristeva que a identidade predominante não é seguida apenas pela apresentação da mesma, mas é também confirmada pela produção do estranho, do abjeto, que funcionam, em contrapartida, como padrões de normalidade, como modos de assegurar as normas regulatórias. Assim, além de abjeção ser compreendida como algo que vai contra as regras, e as desestrutura, pode também ser compreendido como o que tenha a intenção de classificar.

Como dito nos capítulos anteriores, uma das originalidades do modernismo foi a contribuição para a formação de identidades não normativas; reflexo disso é a ambigüidade - um dos temas recorrentes de Sá-Carneiro - realizada sob desejos eróticos e relacionamentos sexuais auto-homo-heterossexuais, nos quais as relações humanas representam uma entrega erótica. Além disso, o modo simbólico da linguagem do autor 
demonstra também os dramas existenciais dos personagens numa sociedade onde se sentem marginalizados, cujo sofrimento sentido no mundo exterior só encontra solução através da arte como forma de expressão interior. Deste modo, em relação a estas identidades sociais minoritárias, e concentrando-se nas facetas representativas dessas na obra, tem-se os homossexuais masculinos.

Percebe-se, então, que abordar a identidade implica também abordar a diferença, já que toda identidade é elaborada pela observação do estranho, organizada pela negação ao estranho, ou seja, a identidade é a negação de marcas culturais que estão presentes por sua ausência. Nessa aplicação da diferença, freqüentemente de maneira dicotômica, existe sempre um modo dominante, do qual se produzem as diferenças relacionadas aos subalternos, sendo que o modo subalterno é constitutivo do modo dominante e essencial para este.

Com a intenção de provocar as dicotomias, fundamentalmente as criadas em torno do gênero e da sexualidade, Judith Butler ${ }^{203}$ propõe uma teoria performativa do gênero e da sexualidade, através da qual busca questionar a elaboração da heterossexualidade como a sexualidade normativa. Segundo a autora, a performatividade é uma citação que confirma e "produz os efeitos"204, em que não somente a possibilidade de repetição, mas também a menção de um signo é fundamental para a produtividade de um enunciado. Partindo de Derrida ${ }^{205}$, Butler utiliza a idéia de que à citação de um signo e sua possibilidade de repetição ad infinitu, independente do contexto no qual foi gerado, faz com que esse signo continue inteligível e produtivo.

A partir dessa concepção de que a linguagem concretiza e cria atos, Butler discute o vínculo entre a performatividade de gênero, materialidade do corpo e sexo,

\footnotetext{
${ }^{203}$ BUTLER, 1999.

${ }^{204}$ Idem, ibidem, p.154

205 DERRIDA, 1991.
} 
revelando que não há sujeitos exteriores ou anteriores às normas regulatórias, mas que o processo de materialização do sexo é formado por meio dessas normas, as quais atuam de modo performativo, para afirmar a heterossexualidade como a sexualidade normativa. Apesar disso, não se sabe a ocasião em que tal construção será finalizada, sendo necessário, portanto uma repetição freqüente em favor da materialização do sexo, por meio de atos performativos.

Ainda segundo Butler, o processo de formação e identificação do sujeito resulta na existência de um espaço de abjeção caracterizado por ser exterior ao sujeito, mas só é identificado como integrante do processo quando também atua "dentro" do sujeito, por meio da (des)identificação. Esse intervalo de abjeção é o lugar em que o sujeito constitui-se, definindo seu campo de valência. Assim, quando se refere a um objeto específico, mesmo que abjeto, está se marcando critérios de referência que tornam possível incluí-lo em áreas de compreensibilidade cultural. Nessas áreas pode-se encontrar o estranho, majoritariamente seres abjetos, criado de modo com que o sujeito reafirme sua identidade (seja ela qual for).

Assim, segundo Butler, não há uma sexualidade originária, mas a predominância de uma heterossexualidade institucionalizada, constructo de aspecto político, tornando-se um modo de opressão. De mesmo modo, o gênero não tem uma identidade imutável como se fosse atributo pessoal, mas deve ser recriado por repetição de atos que ganham legitimidade e naturalidade na sociedade, justamente pela sua reiteração ${ }^{206}$. O principal nessa teoria é a discussão da naturalidade e obrigatoriedade da heterossexualidade.

Voltando-se para A Confissão de Lúcio, o modo como Sá-Carneiro descreve as relações de afeto entre Lúcio, Ricardo e Marta no triângulo amoroso revela essa

\footnotetext{
${ }^{206}$ BUTLER 1990: 25, 33.
} 
desestabilização de identidades eróticas de gênero, demonstrando uma excentricidade esteticista do seu estilo e ambigüidade das relações afetivas quanto ao objeto do amor.

Os personagens chocam-se entre os seus sentimentos e maneiras, os quais, por sua vez, não correspondem com a norma predominante, a qual se forma pela exclusão da experimentação do "outro". Na obra, as condutas não normativas aparecem por meio das confissões dos personagens, em que há conflito entre o que eles sentem e o ser "possível" de se realizar, pois existem divergências discursivas entre o desejo individual e as normas de comportamento.

Esse triângulo erótico, então, revela uma homossexualidade masculina dissimulada, em que a mulher converte-se em um recurso para não violar a norma imperativa da heterossexualidade, ou seja, a transgressão da norma heterossexual é aparentemente censurada através do encobrimento, para não abrir espaço ao questionamento da heteronormatividade - grupo de comportamentos que regulam e normalizam as identidades sexuais e de gênero a partir do relacionamento sexual entre indivíduos de sexo oposto, estabelecido como preferência social, gerando modos, atitudes e procedimentos determinados -, fazendo com que esta seja compreendida como natural (posto ser norma), marginalizando e levando para a anormalidade as outras identidades que se constituem de forma diferente. É importante também ressaltar, que a heterossexualidade é claramente topicalizada nos diálogos de Ricardo e Lúcio ${ }^{207}$ por meio do sujeito masculino, que adquire várias identidades dentro de uma subjetividade fixa.

Marta passa a ser compreendida na obra como a imagem tradicional da mulher e como objeto revelador dos padrões normativos referentes aos comportamentos sociais de relacionamento do gênero. Em algumas passagens da narrativa, a condição do feminino é posta em questão - como nos momentos de dúvida acerca do personagem

\footnotetext{
${ }^{207}$ Ver trecho SÁ-CARNEIRO:1991, 55-56 à página 68.
} 
Marta $^{208}$-, mas isso ocorre sempre por meio da voz masculina, já que o feminino não é aceito como sujeito real nem empírico.

Independentemente de se situar ou não dentro do concordado ou do proibido, o masculino desempenha sempre o papel do sujeito, ao passo que o feminino é reduzido ao lugar de objeto, ou desempenhado por um sujeito masculino. Realmente existe uma oposição entre as identidades sexuais e de gênero dos sujeitos, e os papéis determinados socialmente, revelando conflitos, pois a essência dos sujeitos não coincide necessariamente com a da construção normativa social.

Tendo essa questão cultural-social em vista, pode-se analisar estes aspectos levantados como procedimentos que confirmam a heterossexualidade na obra como norma, pois A Confissão de Lúcio é muito significativa no afirmar-reafirmarconfirmar um modo de sexualidade como normal, natural, bem como, simultaneamente, encobrir o seu reverso, oferecendo, assim, a possibilidade de perceber a heteronormatividade a partir do estranho, do ilegítimo, do monstro.

Ricardo e Lúcio, amparando-se um no outro pelas afinidades que os juntava e os distanciava do mundo exterior, revelam segredos íntimos sobre seus afetos. Ricardo fala a Lúcio a sua vontade profunda de ter maior intimidade com ele, por não conseguir ser amigo daquele por quem sentia desejos de posse, expondo, entretanto, a questão da heterossexualidade normativa, pelo seguinte discurso: "forçoso me seria antes possuir quem eu estimasse, ou mulher ou homem. Mas uma criatura do nosso sexo, não a podemos possuir. ${ }^{, 209}$.

Ricardo aponta várias idéias da masculinidade, como confessando que gostaria de ser bonito (aspecto físico), seu gosto por roupas belas e inclusive a vontade

\footnotetext{
${ }^{208}$ Ver trecho SÁ-CARNEIRO, 1991: 68-69 à página 33.

209 SÁ-CARNEIRO, 1991: 56
} 
de trocar o seu corpo feio por um formoso de mulher. Em seu desejo de assimilação do feminino e do belo, demonstra uma pluralidade identitária de gênero: "E lembra-me então um desejo perdido de ser mulher ${ }^{\text {r210 }}$. Demonstra-se, aqui, a ausência de regras, pois tanto os afetos e os desejos não se direcionam à complementaridade dos sexos biológicos, como os corpos formosos não se restringem às características das mulheres.

Observa-se semelhante desregramento na passagem das "raparigas inglesas" dos music-halls em que Ricardo questiona o gênero estereotipado do feminino, apresentado como o ponto de vista dos homens em relação às mulheres, quando segreda a Lúcio o temor que lhe causam essas mulheres objetos, destituídas de individualidade e vida própria:

“(...). Tenho medo destas dançarinas.

(...)

Ora essas criaturinhas são todas iguais, sempre - vestidas dos mesmos fatos (...), o mesmo ar gentil. De maneira que eu em vão me esforço por considerar cada uma delas como uma individualidade. Não Ihes sei atribuir uma vida - um amante, um passado",211.

A Lúcio, os afetos e o desejo erótico parecem também não estar condicionados pelo princípio de complementaridade do sexo biológico. Inclusive, no relacionamento amoroso com Marta, senti-a "como se ela fosse do meu sexo!" ${ }^{212}$.

Lúcio cultiva uma forte aversão a Sérgio Warginsky, amigo de Ricardo e possuidor de beleza feminina; pela relação de amizade entre estes, sugere-se uma espécie de inveja de Lúcio, mesmo quando ainda desconhece, de fato, o caso amoroso dele com Marta-Ricardo. Embora seja um deuteragonista, é entre ele e Lúcio que principia um sentimento de competição em relação a Ricardo: "Fugiste... E, em verdade, fugiste de

\footnotetext{
${ }^{210}$ Idem, ibidem, p. 54.

${ }^{211}$ Idem, ibidem, p. 43.

212 Idem, ibidem, p. 56.
} 
ciúme... Tu não eras o meu único amigo — eras o primeiro, o maior — mas também por um outro eu oscilava ternuras... Warginsky, tens razão, Warginsky...213.

Essa sensação de afeto um pelo outro está à margem do grupo de personagens. Lúcio e Ricardo sentem afeto um pelo outro por ambos serem também seres ambiguamente estranhos, divididos; Ricardo, apesar de casado - colocando-o numa posição aceitável no grupo -, diz cultuar qualidades não predominantes.

O sentimento máximo de amor é desvelado quando Ricardo faz a seguinte declaração a Lúcio: "Foi como se a minha alma, sendo sexualizada, se materializasse para te possuir (...) Só para ti a procurei... Mas não consinto que nos separe...214. O objeto de desejo para Ricardo é Lúcio e não Marta, revelando que a procurou por ser mulher e poder chegar ao amor físico de Lúcio, confirmando tanto a heteronormatividade como o desregramento.

Marta funciona como a representação da ambigüidade, disfarce à transgressão de uma norma, do desejo erótico não normativo, por representar a materialização da alma de Ricardo. Como esta mulher é expressa pelo sujeito masculino, como sua alma, pode-se dizer que ela não é sujeito empírico (imagem latente da mulher que não existe como sujeito real), mas um recurso espiritual do homem, o feminino como parte do sujeito não adotada, devido a repressão social heteronormativa. Para escapar dessa repressão que privou Ricardo da sua parte feminina, tem-se essa trama, para que a mulher a preencha, lugar onde Ricardo se espelha sem conseguir vê-la.

Este relacionamento triangular erótico homossexual desenvolve-se no ideal dos dois homens, e a mulher, não desempenhando papel de sujeito real e uma pseudoexistência, dissimula uma transgressão sexual de gênero, confirmando a

\footnotetext{
${ }^{213}$ Idem, ibidem, p. 128.

214 Idem, ibidem, p. 129.
} 
heteronormatividade.

A transgressão foi posta claramente por Ricardo, ao confidenciar a Lúcio o seu afeto e necessidade de concretizá-lo pela posse física: "- Ai, como eu sofri... como eu sofri!... Dedicavas-me um grande afeto; eu queria vibrar esse teu afeto - isto é: retribuir-to; e era-me impossível!... Só se te beijasse, se te enlaçasse, se te possuísse... Ah! Mas como possuir uma criatura do nosso sexo?...,215. Demonstra-se que não existe complementaridade heterossexual nos afetos, que o objeto de desejo de Ricardo não segue a heteronormatividade, a rompe, é abjeta por haver - segundo tal norma incompatibilidade entre o desejo e a prática para o alcançar.

Comparando-se o comportamento social de Ricardo e de Lúcio, percebe-se que Ricardo sujeita-se às exigências do regulamento heterossexual institucionalizado. Na sociedade majoritariamente heteronormativa compreende-se como natural a relação entre o sexo biológico e o gênero, em defesa da complementaridade entre o masculino e o feminino. Na declaração de Ricardo a Lúcio há uma rejeição ao seu sexo biológico, com insinuações eróticas sobre a homossexualidade feminina, como fonte de prazer a um homem aparentemente avesso a seu próprio sexo: "Se eu fosse mulher, nunca me deixaria possuir pela carne dos homens"216.

Vale destacar o trecho no qual a "relação conjugal" de Ricardo e Marta é pela primeira vez anunciada: "Eu sabia já, é claro, que o poeta se casara há pouco, durante a minha ausência. Ele escrevera-mo na sua primeira carta; mas sem juntar pormenores, muito brumosamente — como se se tratasse de uma irrealidade. ${ }^{, 217}$.

A constatação de Lúcio confirma a heterossexualidade como norma, através da união conjugal, evitando a total confusão de fronteiras, do cogitar outras possibilidades

\footnotetext{
215 Idem, ibidem: 127.

${ }^{216}$ Idem, ibidem: 54.

${ }^{217}$ Idem, ibidem: 60
} 
de união afetiva. Ao final da narrativa, sabe-se que no plano real, de fora, esposo e esposa estão juntos e teoricamente desaparecem no mesmo momento, confirmando a natural união heterossexual como destino comum para ambos.

Para Lúcio não existem classes sexuais absolutas para o desejo, pressuposto da cultura heterossexual, em que as identidades masculinas e femininas são opostas umas às outras. Isso fica patente na diferença entre a "verdade" normativa e a que é revelada por Lúcio. A ausência de diferenciação dos gêneros comprova a possibilidade da erotização entre seres do mesmo sexo, oposta à heteronormatividade.

Em $A$ Confissão de Lúcio a abjeção é criada mais como uma forma de construção (e confirmação) da heteronormatividade; mas, atentando-se à idéia de Butler, de que o sujeito é formado pela força da exclusão e da abjeção, muitas vezes, o estranho, o abjeto, pode ser reconhecido a partir do próprio sujeito, por meio de comportamentos, falas, movimentos que ocasionalmente sugerem sua passagem pela severa área da abjeção.

Em grande parte da obra, Ricardo está na área limítrofe entre o feminino e o masculino e para esquivar-se de uma mudança de sua identidade "correta", cria Marta, que preza pela manutenção de sua identidade masculina.

Ao transitar pela experiência de tornar-se uma "mulher", Ricardo identifica o estranho como alguém que quer ser, mas não o pode no plano real - a feminilidade aparece como uma área de abjeção, o estranho, por outro, ela também está dentro do próprio Ricardo, configurado pela iminente feminilidade que ele precisa criar para não perder seu Amor.

O estranho não é uma criação pós-moderna, está presente desde antigas narrativas da história da humanidade, exemplos disso são na ldade Média, quando arte e 
literatura estavam repletas de seres grotescos, ou na mitologia grega com semideuses, ou nos clássicos contos com feiticeiras e dragões. O estranho também é reconhecido por outras palavras, como grotesco ou abjeto, por terem significados iguais: o que se afasta à norma, ao padrão, assegurando, em contrapartida, sua existência.

Algumas pesquisas realizadas sobre o grotesco apontam-no como algo que integra nossa humanidade e subjetividade, como a realizada por Wieland ${ }^{218}$ no final do século XVIII, que assegura a essência do grotesco estar na interrupção de qualquer relação bem clara com a realidade, destacando o absurdo, o sobrenatural, ludibriando as regras que regem a realidade. A importância da pesquisa de Wieland está na análise dos resultados psíquicos do grotesco e do sentido deste transferido do exterior para o interior, tornando impraticável não conhecê-lo.

Com essas diferentes abordagens percebe-se que a forma da heteronormatividade na obra $A$ Confissão de Lúcio é construída a partir do estranho, do abjeto, como medida de normalização. Não necessariamente tratado como o inimigo, o abjeto torna-se então o lugar recusado ou rejeitado por não ser o espaço onde as normas regulatórias que regem a conduta dos sujeitos podem ser reconhecidas; podendo, ainda, estar dentro deles próprios. $E$ isso é feito através do modo como o abjeto é representado na obra, no confronto com o indesejável para se ter certeza do desejável.

O silêncio entre os personagens do triângulo erótico de relacionamento é mantido, em relação às identidades sexuais, evitando conflito com a heteronormatividade e possibilitado espaço dentro da arte. Lúcio está consciente que o lugar da não normatividade foi deixado à expressão artística, onde ele se resguarda com as suas verdades interiores.

${ }^{218}$ apud KAYSER, 1986. 


\section{A guisa de conclusão}

De um modo geral, os textos de Mário de Sá-Carneiro, apresentam-se como esboços ou idéias incompletas, o que de certo modo atrapalha o exercício de reconstituição do que poderia ter sido o seu pensamento estético, revelando, entretanto, o grande e variado talento imaginativo que o singularizou. Predomina nesse poeta a intensidade, tanto emocional como sensitiva, e isso ofusca o olhar analítico, dificultando, em parte, uma leitura que se queira racional e crítica, como aborda Galhoz:

"Os sentidos assumem no enigma deste repetido debate uma importância muito exclusiva, pois (...) são eles os mais brilhantes intérpretes duma espécie de inteligência intuitiva que não consegue seu equivalente em compreensão racionalizada, e daí o desequilíbrio em que brilham e se consomem. ${ }^{219}$

Portanto, não há maneira de encontrar "um" ou "o sentido" nas escritas de Sá-Carneiro, como ele propriamente avisa, propondo o perigo casualmente redutor das tentativas de encontrar uma ou a "explicação" para a obra de arte:

“(...) se nas minhas obras de Arte, vagabundas de miragem, sumptuosas de requinte, ponho um pouco de mim nos protagonistas - gritam logo os castrados à blague ou à incompreensão. Incompreensão... Há tão pouco que compreender no que escrevo - nisto tudo... (...) Não procurem nada (...) - não há nada a perceber. (...) Nem posso exprimir doutra maneira, com maior clareza, porque é assim - assim mesmo."220

\footnotetext{
${ }^{219}$ SÁ-CARNEIRO, 1980, 24 apud GALHOZ, Maria Aliete. "Prefácio" de Céu e Fogo.
}

${ }^{220}$ Idem, ibidem, 62. 
É claro que não podemos aceitar sem resistência essa impossibilidade enunciada pelo artista. Mas que por ela fique evidente, assim, não somente a importância que se fixa em Sá-Carneiro quanto à disposição da sensibilidade à arte, como também a tentativa de elaborar uma poética própria, cuja significação e real enigma, não são as histórias, mas os símbolos que estão por trás delas ${ }^{221}$.

Depara-se, pois, com uma poética essencialmente híbrida, em grande parte constituída por uma composição de 'ismos', dentre os quais se destacam o interseccionismo, o paulismo, e sobretudo o sensacionismo, face mais inovadora e própria do autor. Sá-Carneiro mistura-os, amplia-os, criando um "campo impuramente psíquico e estético, criando uma arte feita de realismo e de fantástico, de fetichismo e severa inquietação,222.

A Confissão de Lúcio, publicada pelo poeta em 1914, um ano antes do aparecimento do primeiro número de Orpheu, é uma narrativa que parece apresentar, através da fragmentação, a existência de questões que ficam sem resposta no enredo: repetição de silêncios intervalares, espelhamentos intertextuais como forma de dar consistência à voz do autor, que está consciente de que esse material que utiliza é aquilo com que se constrói a obra de arte, cuja linguagem é plástica e maleável, criadora de um sentido provisório e impossível de fixar, uma vez que resiste ao entendimento racional.

É interessante recolher, nesse momento, os enigmas irresolúveis do texto: Lúcio teria habitado uma prisão ou um manicômio? A apontada semelhança entre o juiz que o interrogara e o médico que o tratara de uma febre cerebral não indicaria que um deles (ou os dois) é produto do delírio imaginativo do narrador? Teria Marta existido, ou seria ela apenas uma criação ficcional que camuflaria um relacionamento sexual entre os dois amigos? Como se explicaria o seu desaparecimento simultâneo à morte de Ricardo

\footnotetext{
${ }^{221}$ Idem, ibidem, 14 apud GALHOZ.

222 Idem, ibidem, 25 apud GALHOZ
} 
de Loureiro? E especialmente seria preciso atentar para o fato de Lúcio ser uma personagem que narra a sua história a partir de uma memória sempre posta em questão, a mesma memória que se transubstancia imaginativamente no escritor de novelas, no autor de peças de teatro e no crítico de arte, espectador privilegiado do processo criador de outras personagens.

Sugere-se, pois, que a narrativa é uma criação ficcional, uma elaboração de linguagem, sem estatuto de verdade, desmistificando o sentido dessa obra enquanto confissão jurídica ou depoimento.

Eis alguns elementos que concorreriam para desmistificar a novela como mimese e representação do real objetivo, acentuando o seu caráter de produção da qual o leitor participa: a constante preocupação com os temas da representação, da criação, do fingimento; a presença de máscaras, espelhos, duplos (não seria Ricardo de Loureiro um duplo de Gervásio Vila-Nova, e não seria Marta um duplo de Ricardo de Loureiro?); a preocupação do texto com reduplicação, desdobramento e ruptura da ilusão; a fragmentação de seu enunciado, o que poderia ser visto como mais um sinal de sua artificialidade, de seu caráter de ficção.

Ao desnudar os processos utilizados na elaboração do texto, ou ainda, ao usar elementos que testemunham ser ele resultado de um trabalho consciente de criação, essa literatura fala de si e de seu tempo, mas, simultaneamente, diz mais do que está dito. Pode comover ou escandalizar o leitor com o enunciado que the apresenta e que retrata o mundo em que ele vive, mas ao romper declaradamente a ilusão da representação da realidade, valoriza a elaboração do texto e o seu receptor, co-produtor, de quem dependerá afinal a existência da obra.

A finalização, leitura, representação ou execução de obras de arte, na narrativa (como "A Chama" de Lúcio e "Brasas" de Ricardo), coincidem com 
acontecimentos fundamentais do seu enredo, de forma a deixar no leitor a impressão de correspondência entre as obras concluídas na diegese e os episódios narrados da vida de Lúcio ou, ainda, gerar dúvidas quanto à veracidade dos fatos.

As várias coincidências ou espelhamentos, presentes no texto, parecem confirmar essa idéia de que a obra se dobra sobre si mesma, utilizando os seus próprios elementos como material de sua construção, como: na "orgia de fogo" da Americana, com sua idéia da "voluptuosidade da arte", que é simultânea ao encontro de Ricardo e Lúcio a relação nasce numa pára-realidade; na conclusão da obra de Ricardo ("Diadema"), coincidente à união amorosa de Lúcio e Marta, que embora se configure como o triunfo maior (relação de Lúcio e Ricardo), pode ser vista como registro do esforço e do tempo despendidos pelo "autor" na elaboração de sua obra; o título "Brasas", que poderia se referir ao relacionamento dos dois amigos, mas também ao calor e ao entusiasmo de uma obra que pretendia valer por si, independentemente de seu valor de mercadoria, determinado por uma sociedade interessada apenas no aspecto comercial da arte.

Além destes elementos, existem outras histórias contadas ou obras criadas pelas personagens e encaixadas en abyme no plano da narrativa, nela funcionando como espelhamentos que, junto às idéias de máscara e de duplo, sinalizam a divergência entre os diferentes planos da novela, que é apresentada assim numa perspectiva de jogo e de ambigüidade. Entre elas estariam: a narrativa de Ricardo, de seu encontro com as duas moças gentis em Paris ${ }^{223}$; as histórias não contadas, como a da vida pregressa de Marta e a do seu casamento com Ricardo de Loureiro; as histórias de Raul Vilar, com o seu desvendamento da vida íntima dos companheiros.

\footnotetext{
223 "Uma tarde de abril, há três anos, caminhava nos grandes bulevares, solitário como sempre. De súbito, uma gargalhada soou perto de mim... Tocaram-me no ombro... Não dei atenção... Mas logo a seguir me puxaram por um braço, garotamente, com o cabo de uma sombrinha... Voltei-me... Eram duas raparigas... duas raparigas gentis, risonhas... Àquela hora, duas costureiras - decerto - saídas dos ateliers da Rua da Paz. Tinham embrulhos nas mãos... E uma delas, a mais audaciosa:

'-Sabe que é um lindo rapaz?" (SÁ-CARNEIRO, 1991: 53).
} 
Embora envolva o leitor na trama construída, a obra fornece-lhe sinais de que faz paródia de si mesma, na medida, por exemplo, em que apresenta um narrador com a consciência de ser também um primeiro leitor, o qual comenta e faz digressões acerca de possíveis dúvidas sobre o que narra, além de marcar a sua construção com imensos vazios, num convite à participação imaginativa e lúdica do receptor.

A narrativa oscila entre mimese e construção, entre apresentação e representação, atribuindo ao dito apenas um valor parcial/provisório, revelando-se como ato discursivo elaborado a partir dos pressupostos que acabam por emaranhar-se em profundidades outras, até subversivas, uma vez que instituem a leitura como operador desse mesmo ato. Assim, a narrativa, em seu perfil metafórico, funciona como suporte do que deseja recalcar superficialmente.

A narração é estruturada em função do "eu" narrativo, ou seja, apresenta ponto de vista interno. O narrador subjetivo é acusado de homicídio, com todas as provas circunstanciais bem apresentadas, mas só narra os episódios após o cumprimento da pena, que foi de 10 anos, desenrolando-se então um fio narrativo bastante complexo: refaz-se a aventura de percorrer novamente o reconhecimento de um elo entre o "eu", percebido, e o "outro", adivinhado, aceitando o perigo de confundir os limites proibitivos de ambos, na mesma medida em que essa voz também se coloca numa fronteira, a saber, entre a vida e a morte, dando-se a conhecer como um morto que persiste.

Numa escrita decadentista, excessivamente decorada de apelos sensoriais (veludos, cores douradas, perfumes, formas arredondadas, brilhos, vultos longilíneos), o leitor é levado a tentar decifrar uma construção sofisticada de linguagem, permeada de detalhes preciosos e enigmáticos que apontam para uma sensualidade marcada por um veto moral explícito, o qual se sustenta no triângulo imaginado e desejado (baseado no duplo Lúcio-Ricardo), mas que não podia ser "vivido", devido à presença difusa de Marta 
(ser fantástico vinculado às pulsões e recalque). O erotismo que ressuma da crescente tensão sensual descrita fala mais do desejo de uma aproximação entre dois amigos - "eu" e o "outro": identidades complementares e intensamente ligadas, o duplo -, não suportada nem mesmo no contexto parisiense de "fim de século", mas criada por Sá-Carneiro como ficção.

Todo ato de "confissão" implica uma vontade de prestar contas, que pode representar, em maior ou menor grau, uma "culpa", uma responsabilidade civil ou criminal a qual se quer expiar diante do outro. A primeira vista, o título já é altamente indicial dessa vontade de auto-expiação, dando-Ihe a conformação de "documental", como se pode ler já na primeira página: "A minha confissão é um mero documento,224. Assim, abre-se o palco no qual se vai encenar o drama de Lúcio: no início, a tentativa e a vontade, entre frustrada e vitoriosa, de confessar um delito e no final, o fracasso e o desencanto em face de um crime deliberadamente arquitetado, confesso, mas que resulta inverossímil. Os leitores são postos no lugar de júri, lugar de comprometimento pelo destino que não é mais o do narrador-protagonista, mas o de qualquer sujeito que, diante de um episódio, vê-se no exercício da sua condição de interventor, construindo, reconstruindo, configurando um espaço de representação.

Nesse sentido, é relevante apontar a questão da representação em $A$ Confissão de Lúcio: a "realidade inquietante" que permeia toda a narrativa, a partir da dubiedade com que o narrador-protagonista focaliza e analisa o drama, é o operador que desorienta a visão do leitor, obrigando-o a confrontar sua ilusão de referencialidade. SáCarneiro aprofunda o questionamento acerca da representação muito além de uma simples dicotomia que separa o mundo da representação em pólos tão extremos como "real" e "imaginário". Também os próprios seres e coisas são apreendidos para além de sua constituição estabelecida mediante o código social, fugindo a uma gramática da

\footnotetext{
${ }^{224}$ Idem, ibidem, p. 17.
} 
realidade, da norma, e, portanto, segundo Kristeva ${ }^{225}$ também caracteristicamente abjeta, por ser um momento de fronteira, de questionamento, de quebra de regras.

Como dito nos capítulos anteriores, uma das originalidades do modernismo foi a contribuição para a formação de identidades não normativas; reflexo disso é a ambigüidade - um dos temas recorrentes de Sá-Carneiro - realizada sob desejos eróticos e relacionamentos sexuais auto-homo-heterossexuais, nos quais as relações humanas representam uma entrega erótica. Além disso, o modo simbólico da linguagem do autor demonstra também os dramas existenciais dos personagens numa sociedade onde se sentem marginalizados, cujo sofrimento sentido no mundo exterior só encontra solução através da arte como forma de expressão interior.

Percebe-se em Sá-Carneiro uma pretensão de transgredir as leis da natureza, não só pela projeção da alma como também pela tentativa de encontrar o "outro" identitário. Nesta linha de pensamento, vê-se uma atitude de identificação com as idéias da abjeção de questionamento à ordem estabelecida, na qual a controvérsia das identidades de gênero em relação ao posicionamento do feminino-masculino dos personagens se vincula uma pretensão de vínculo do material com o espiritual, almejando atingir a perfeição. É importante ressaltar que essa desconstrução da oposição entre os gêneros e identidades sexuais não excludentes, mas que se fundem, abrindo espaço (mesmo que implícito) à homossexualidade, remete a um tipo de androginia.

Entre os métodos usados para confirmar a heteronormatividade, estão os enunciados dos personagens Lúcio e Ricardo, de modo a originar identidades de gênero e sexuais confirmando a heterossexualidade como norma. Vale também observar e confirmando o postulado de Kristeva e Butler de que a identidade predominante não é seguida apenas pela apresentação da mesma, mas é também confirmada pela produção

\footnotetext{
${ }^{225} \mathrm{~J}$. Kristeva demonstra sobretudo a sua potencialidade de romper a ideologia através da característica fundamental da transformação.
} 
do estranho, do abjeto, que funcionam, em contrapartida, como padrões de normalidade, como modos de assegurar as normas regulatórias.

Esse questionamento aflora na prosa de Sá-Carneiro mediante um agenciamento discursivo que prevê, num mesmo processo, uma noção de sujeito que busca sua constituição a partir de e na linguagem que vai selecionando objetos, os quais refletem, em sua característica singular, uma forma compósita de argamassa, de ligamento. O narrador-protagonista da "confissão" parece tentar construir o que, em si, é desconstrução ${ }^{226}$.

Na ânsia de tornar possível a captação do real, que se traveste em significantes do irreal (como o caso explícito de Marta), o narrador lança mão de sintagmas/significantes de ligamento que perpassam toda a obra e se entre-ofuscam, como o "globo", as "transparências" e o "meteórico" que subvertem o espaço da representação, apoteotizando- $o^{227}$. O narrador-protagonista arrasta consigo o leitor, e ambos penetram na simultaneidade desses significantes que não chegam a se construir como permanência e continuidade, mas como coisas estilhaçadas, dispersas no tempo e no espaço, pois nada fica claro ou inteiramente definido.

A grande questão tematizada, ou dramatizada, na escrita de Sá-Carneiro, é precisamente a do sujeito na linguagem, assinalada por um egotismo estetizante ou pequeno-narcísico, sob o qual o sujeito, dilacerado, vai se desenhando por entre objetos fragmentados e quebradiços, ao mesmo tempo em que revela um novo modo de perceber e representar a "realidade". Assim, a narrativa da "confissão" representa um mundo como imagem completa do caos e do que não se pode explicar.

\footnotetext{
226 O narrador intitula-se como morto-vivo, encontra-se desconstruído, apenas reconstituindo fatos rememorados, passados.

${ }^{227}$ Termo utilizado por Sá-Carneiro, cujo sentido é referente, ao tom de engrandecimento pela presença do sublime e da mistificação.
} 
O espelho poliédrico, em que se projeta o narrador, encadeia um processo de espelhamentos sucessivos, representados pelas personagens que funcionam como recortes/aspirações de sua própria identidade, metáfora da condição humana em fragmentação. Com a moderna filosofia e a superação do cogito cartesiano, o conceito de sujeito passou por uma reavaliação: o sujeito não é mais uno, inteiro, coerente, harmonioso, mas uma rede, um simulacro de identidades. Confissão é também confissão, fissura do sujeito, separação, uma "fissão" simultânea entre as representações sígnicas que o sujeito erótico projeta sobre si mesmo, como representações de desejo.

A linha que nos separa do mundo, que nos confere nossa identidade, é a mesma que torna possível a existência da que traça para nós o contorno dos objetos no mundo visível. Se a fronteira que nos separa do mundo se enfraquece, se regressamos à situação infantil e primitiva de indiferenciação e continuidade com o exterior, as representações tendem a se tornar pouco nítidas, seus limites se borram, os objetos tendem a se fundir uns aos outros, e a totalidade das formas caminha para uma subordinação das partes ao todo e uma continuidade que caminha para a indistinção.

Assim é o universo ficcional de Sá-Carneiro: um mundo de brumas, em que todas as formas se esboçam e têm grandes extensões de território comum com outras formas. Seus personagens se superpõem, gestos de uns transformam-se em gestos de outros, ações de uns trocam-se em ações de outros, atributos de um tornam-se atributos de muitos.

Sá-Carneiro, nessa narrativa, esmera-se em desenvolver pequenas e breves confissões especulares, duplicadoras de sua confissão maior. É Ricardo quem indicia a Lúcio a fragmentação do "eu" ao lhe revelar o seu drama afetivo que era amar pessoas do mesmo sexo, seus medos e obsessões, a amizade como sentimento misto de ternura e posse: “(...). Logo eu só poderia ser amigo de uma criatura do meu sexo, se essa criatura 
ou eu mudássemos de sexo.. ${ }^{.228}$. A necessidade (quase condição sine qua non) de mudança de sexo, para a efetivação da relação afetiva (homoerótica) entre os dois amigos, que reclama uma realização definitiva, deixa entrever o traço homofóbico, que a triangulação afetiva acaba por expor.

A sucessão de máscaras atende, por fim, à urgência de mascarar o homoerotismo, alvo de milenar interdição cultural. A ambigüidade da morte de Marta é também a ambigüidade da morte de Ricardo. Símbolo central de permanência em si mesmo, como Narciso, Lúcio cria, a partir dessas confidências, sua pretensa e ambígua confissão, como estratégia para compreender-se como sujeito em processo de fragmentação e dispersão que se abre para o encontro com o "outro". Nessa obsessão, a própria paixão pela cidade de Paris possui um traço revelador de seu homoerotismo, na medida em que encobre sutil alusão a Páris, o homem que protege Helena no mito grego: "De novo, urgindo-me de Europa, alastrando-me da sua vibração, se encapelava dentro de mim Paris - o meu Paris, o Paris dos meus vinte e três anos... ${ }^{229}$.

A confissão de Ricardo transporta a intriga para os domínios do interdito, do segredo, do mistério, da esfinge, maneira cifrada de nomear a necessidade de se criar uma justificativa social e moral para a relação homoerótica. Ricardo cria, então, Marta como um monstro ou criatura representativa do lado reprimido de Lúcio e, como tal, fadada a resistir às conseqüências de sua não normatividade sob a forma de repulsa.

Estando Lúcio incompleto, instala-se nele um quadro de profunda tristeza, pois a impossibilidade de realizar um desejo prospectivo sempre provoca, no homem, grave alteração no seu estado psíquico, acirra um quadro depressivo, já que o fim da

\footnotetext{
${ }^{228}$ Idem, ibidem, p. 56

${ }^{229}$ Idem, ibidem, p. 112
} 
vida, ao aproximar-se, deixa-o num compasso de espera e melancolia. Freud ${ }^{230}$ a esse respeito fala de forma bastante clara:

"O impulso de vida e o impulso de morte habitam lado a lado dentro de nós.

A morte é a companheira do amor. Juntos eles regem o mundo. (...) No começo a psicanálise supôs que o amor tinha toda a importância. Agora sabemos que a morte é igualmente importante. Biologicamente, todo ser vivo, não importa quão intensamente a vida queime dentro dele, anseia pelo Nirvana, pela cessação da 'febre chamada viver' anseia pelo seio de Abraão. O desejo pode ser encoberto por digressões. Não obstante, o objetivo derradeiro da vida é sua própria extinção."231

Atingir o nirvana e delirar são conceitos relacionados à volúpia como o mais alto grau de uma espiritualidade corpórea, um espasmo. Há um total desregramento dos sentidos (compreendidos aqui tanto como significados, quanto sensações) na obra, prezase por isso na escrita ou linguagem, nos elementos narrativos, onde se cria essa embriaguês: nada é certo, mas vago. O desejo, a perversão, a fantasia estão libertas. Deste modo, a obra aborda a voluptuosidade, a encena de maneira crescente, pois a Americana primeiramente a teoriza e expõe $e^{232}$ mais diretamente no espetáculo fantástico em sua casa, e Lúcio junto aos protagonistas a experimenta, a vive, por ser fragmentado, plural, abjeto.

\footnotetext{
${ }^{230}$ FREUD, 1926.

${ }^{231}$ Idem, ibidem, p. 4.

232 “(...) Ah! mas aquele que fosse um grande artista e que, para matéria-prima, tomasse a voluptuosidade, que obras irreais de admiráveis não altearia!... Tinha o fogo, a luz, o ar, a água, e os sons, as cores, os aromas, os narcóticos e as sedas - tantos sensualismos novos ainda não explorados... Como eu me orgulharia de ser esse artista!... E sonho uma grande festa no meu palácio encantado, em que os maravilhasse de volúpia... em que fizesse descer sobre vós os arrepios misteriosos das luzes, dos fogos multicolores - e que a vossa carne, então, sentisse enfim o fogo e a luz, os perfumes e os sons, penetrandoa a dimaná-los, a esvaí-los, a matá-los!... Pois nunca atentaram na estranha voluptuosidade do fogo, na perversidade da água, nos requintes viciosos da luz?.. Eu confesso-lhes que sinto uma verdadeira excitação sexual - mas de desejos espiritualizados de beleza - ao mergulhar as minhas pernas todas nuas na água de um regato, ao contemplar um braseiro incandescente, ao deixar o meu corpo iluminar-se de torrentes elétricas, luminosas... Meus amigos, creiam-me, não passam de uns bárbaros, por mais requintados, por mais complicados e artistas que presumam aparentar!" (SÁ-CARNEIRO: , 1991: 24).
} 
Em outras palavras, o texto analisado de Sá-Carneiro desliza perfeitamente entre os conceitos freudianos e kristevianos, com mais perguntas que respostas, voltando-se sobre si próprio ao enfatizar o espírito da procura, e organizando-se em torno da literatura essencial a se discutir, seja através do bem ou do mal, do belo ou do grotesco, da literatura a expurgar o conhecimento do lado contrário. 


\section{Bibliografia}

1. Mário de Sá-Carneiro

SÁ-CARNEIRO, Mário de. A Confissão de Lúcio. Coleção Prestígio. Ed. Ediouro. Rio de Janeiro - RJ, 1991.

. Cartas a Fernando Pessoa. I Volume, Lisboa, Ática, 1978.

. Cartas a Fernando Pessoa. II Volume, Lisboa, Ática, 1979.

. Céu em Fogo. Lisboa, Ática, 1980.

. Obra completa. Rio de Janeiro: Nova Aguilar, 1995.

. Obra Poética. Rio de Janeiro, Nova Aguilar, 1977.

Poesias. Lisboa, Ática, 1978.

2. Orpheu

Orpheu, Vol. I, Lisboa, Ática, s/d (1를 ed. Janeiro/Fevereiro/Março de 1915).

3. Geral

AA.VV. Colóquio / Letras, número 117-118 ("Mário de Sá-Carneiro há cem anos do seu nascimento"), 1990.

AA.VV. Vértice, número 36 ("Mário de Sá-Carneiro"), Março de 1991.

ANDRADE, Ione de. "Realismo Fantástico e Simbolismo dos Trajes na 'Confissão de Lúcio", In: Bolletin des Estudes Portugaises. Institut Français au Portugal. Novelle Série, Tone vingt-huit/vingt-neuf, 1967/68. 
BAUDELAIRE, Charles. Escritos íntimos. Lisboa: Estampa, 1982.

BENJAMIM, Walter. Magia e técnica, arte e poética. 3 ed. São Paulo: Brasiliense, 1987. Vol I.

BOSI, Alfredo. O Ser e o Tempo da Poesia. São Paulo: Cultrix, 1977.

BOURNEUF, Roland. \& QUELLET, Real. O Universo do Romance. Coimbra, Livr. Almedina, 1976.

BRUNEL, Pierre (org.). Dicionário de mitos literários. Rio de Janeiro: Editora UNB/José Olympio, 2000.

BUTLER, Judith. Problemas de gênero. Feminismo e subversão da identidade. Rio de Janeiro: Civilização Brasileira, 2003. . "Corpos que pesam: sobre os limites discursivos do 'sexo', In: LOURO, Guacira Lopes. O corpo educado: pedagogias da sexualidade. Belo Horizonte: Autêntica, 1999.

CASTEX, François. Mário de Sá-Carneiro e a Gênese de Amizade. Liv. Almedina, Coimbra, 1971.

COMPAIGNON, Antoine. O demônio da teoria: literatura e senso comum. Belo Horizonte, Ed. UFMG, 2003.

DERRIDA Jacques. "Assinatura, acontecimento, contexto", In: Limited Inc. São Paulo: Papirus, 1991.

FERREIRA, Hermelinda. "Olho Mágico: o princípio estético do sensacionismo pessoano", In: Na véspera de não partir nunca: 70 anos sem FP. Recife. Programa de pós da UFPE, 2005, col. Letras.

Foucault, Michel (1997). A Ordem do discurso. Lisboa: Relógio D’Água. . O que é um autor? Trad. Antônio Fernando Cascais e Eduardo Cordeiro. Veja Passagens, 1992.

FREUD, S.. Além do Princípio do Prazer. Rio de Janeiro: Imago, 1998. 
. (1919). "O estranho". In: Obras Completas. Rio de Janeiro: Imago, 1990. Vol XVII.

. (1914). "Sobre o narcisismo: uma introdução", In: Obras Completas, Rio de Janeiro: Imago, 1990. Vol XIV.

. (1926) A questão da análise leiga. Edição Standard Brasileira das Obras Psicológicas Completas de Sigmund Freud. Vol. XX. Rio de Janeiro: Imago Editora; 1976.

FRIEDRICH, Hugo. Estrutura da lírica moderna. São Paulo: Duas Cidades, 1978.

FRYE, Northrop. Anatomia da crítica. São Paulo: Cultrix, 1973.

GALHOZ, Maria Aliete. Mario de Sá-Carneiro. Lisboa, Editorial Presença. 1963. . "O Momento Poético do Orpheu", In: Orpheu, vol 1, 2

reedição. Lisboa, Ática, 1971.

GUSDORF, Georges. Mito y Metafísica. Buenos Aires, Nova, 1960.

ILARCOURT, Brace. Aspects of the novel. NY. 1954. Aspectos do Romance. PA, Ed. Globo, 1974.

JÚDICE, Nuno. "Mário de Sá-Carneiro: ele próprio e o outro", In: O Processo Poético - Estudos de Teoria e Crítica Literárias. Lisboa: Imprensa Nacional/ Casa da Moeda. 1992.

KAYSER, Wolfgang. O grotesco: configuração na pintura e na literatura. São Paulo: Perspectiva, 1986.

KRISTEVA, J., Powers of horror: an essay on abjection, (transl. by L.S.Roudiez), New York: Columbia University Press, 1985.

LALANDE, André. Vocabulário técnico e crítico da filosofia. São Paulo: Martins Fontes, 1999.

LEFEBVE, Maurice-Jean. Estrutura do Discurso da Poesia e da Narrativa. Coimbra, Livr. Almedina, 1980. 
LIND, G. Rudolf. "O Sensacionismo - o equivalente português do futurismo", In: Estudos sobre Fernando Pessoa. Imprensa Nacional - Casa da Moeda, 1981.

LOPES, Óscar. "Mário de Sá-Carneiro", In: Entre Fialho e Nemésio - Estudos de Literatura Portuguesa Contemporânea. Vol. II. Lisboa: Imprensa Nacional / Casa da Moeda, 1987.

LOPES, Teresa Rita. "O monólogo/ diálogo do 'Esfinge Gorda'". Apud AA.VV. A Phala - Um Século de Poesia (1888-1988). Lisboa: Assírio \& Alvim, 1989, pp. 33-35.

LOURENÇO, Eduardo. O Labirinto da Saudade - Psicanálise mítica do destino português. Lisboa, Publicações D. Quixote, 1982. Tempo e Poesia. Porto, Inova, 1974.

MARTINS, Fernando Cabral. O Modernismo em Mário de Sá-Carneiro. Lisboa: Editora Estampa, 1994.

MAIOR, Dionísio Vila. O sujeito modernista Fernando Pessoa, Mário de SáCarneiro, Almada Negreiros e António Ferro crise e superação do sujeito. Temas educacionais. Universidade aberta, 2003.

MOISÉS, Massaud. A criação literária: prosa. São Paulo: Cultrix, 1985.

MORÃO, Paula. "Algumas marcas simbolistas na poesia de Mário de Sá-Carneiro", In: Viagens na Terra das Palavras. Ensaios sobre Literatura Portuguesa. Lisboa: Cosmos. 1993, pp. 41-55.

NOVALIS. Himnos a la noche - Cantos espirituales. Córdoba: Assandri, 1953.

NIETZCHE, Friedrich Wilhelm. A origem da tragédia. Lisboa: Guimaraes, 1994.

PAIXÃO, Fernando. Narciso em sacrifício: a poética de Mário de Sá-Carneiro. Atelie Editorial, 2003.

PESSOA, Fernando. Cartas a Armando Cortes-Rodrigues. Introdução por Joel Serrão, Lisboa, Horizonte, 1985. 
. Obra Poética. Editora Nova Aguilar, Rio de Janeiro, 1986, 4ª impressão da 9르 edição.

. Páginas de Estética e de Teoria e Crítica Literária. Lisboa,

Edições Ática, 1973.

. Páginas de Doutrina Estética, Lisboa, Inquérito, 1946.

. Páginas Íntimas e de Auto-Interpretação, Lisboa, Ática, s/d.

. "Poesias Coligada/Inéditas. 1919-1935", In: . Obra

Poética. Volume único.

- Textos de Intervenção Social e Cultural. Lisboa, Europa

América, 1986.

PIEDADE, Ana Nascimento. A questão estética em Mário de Sá-Cameiro (prefácio de E. Lourenço). Lisboa, Universidade Aberta, 1994.

REIS, A. O., MAGALHÃES, GONÇALVES,. "Teorias da personalidade em Freud, Reich e Jung", In: Temas Básicos da Psicologia. Vol. 7. São Paulo: EPU, 1994.

RIMBAUD, Arthur. Poésies. Paris: Mercure de France, 1950.

ROCHA, Clara Crabbé. O essencial sobre Mário de Sá-Carneiro. Imprensa Nacional-Casa da Moeda, 1985.

RUSSO, Mary. O grotesco feminino: risco, excesso e modernidade. Rio de Janeiro: Rocco, 2000.

SAMPAYO, Nuno de. "A Frustração na Obra Poética de Mario de Sá-Carneiro", In Russo, ano III, num. 36, 1960

WOODWARD, Kathryn. "Concepts of Identity and Difference", In: WOODWARD, Kathryn, ed. Identity and Difference. London: Sage Publications, 2002.

WOLL, Dieter. "A lírica de Mário de Sá-Carneiro vista por um alemão", In: Colóquio - Revista de Artes e Letras. n 5 e 6, Lisboa, Novembro de 1959. 